\title{
Surficial Geology of
}

Anchorage and Vicinity

Alaska

GEOLOGICA L SURVEY B ULLETIN 1093

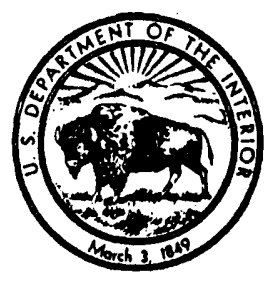





\section{Jurficial Geology of}

\section{Anchorage and Vicinity}

\section{Alaska}

By ROBERT D. MILLER and ERNEST DOBROVOLNY

3 E O L O G I AL S U R VEY B ULLE T I N 1093

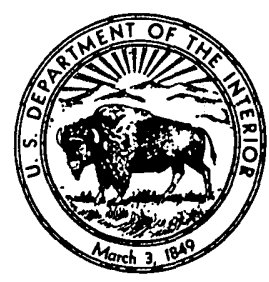




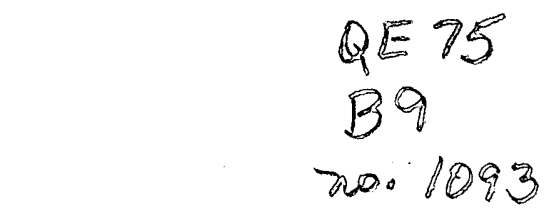

UNITED STATES DEPARTMENT OF THE INTERIOR

FRED A. SEATON, Secretary

GEOLOGICAL, SURVEY

Thomas B. Nolan, Director

The U.S. Geological Survey Library has cataloged this publication as follows :

\section{Miller, Robert David, 1922-}

Surficial geology of Anchorage and vicinity, Alaska, by Robert D. Miller and Ernest Dobrovolny. Washington, U.S. Govt. Print. Off., 1959.

จ, 129 p. illus., map, diagrs., tables. $24 \mathrm{~cm}$. (U.S. Geological Survey. Bulletin 1093)

Part of illustrative matter folded in pocket.

Bibliography : p. 122-125.

1. Geology-Alaska-Anchorage area. I. Dobrovolny, Ernest, 1912joint author. II. Title. (Series) 


\section{CONTENTS}

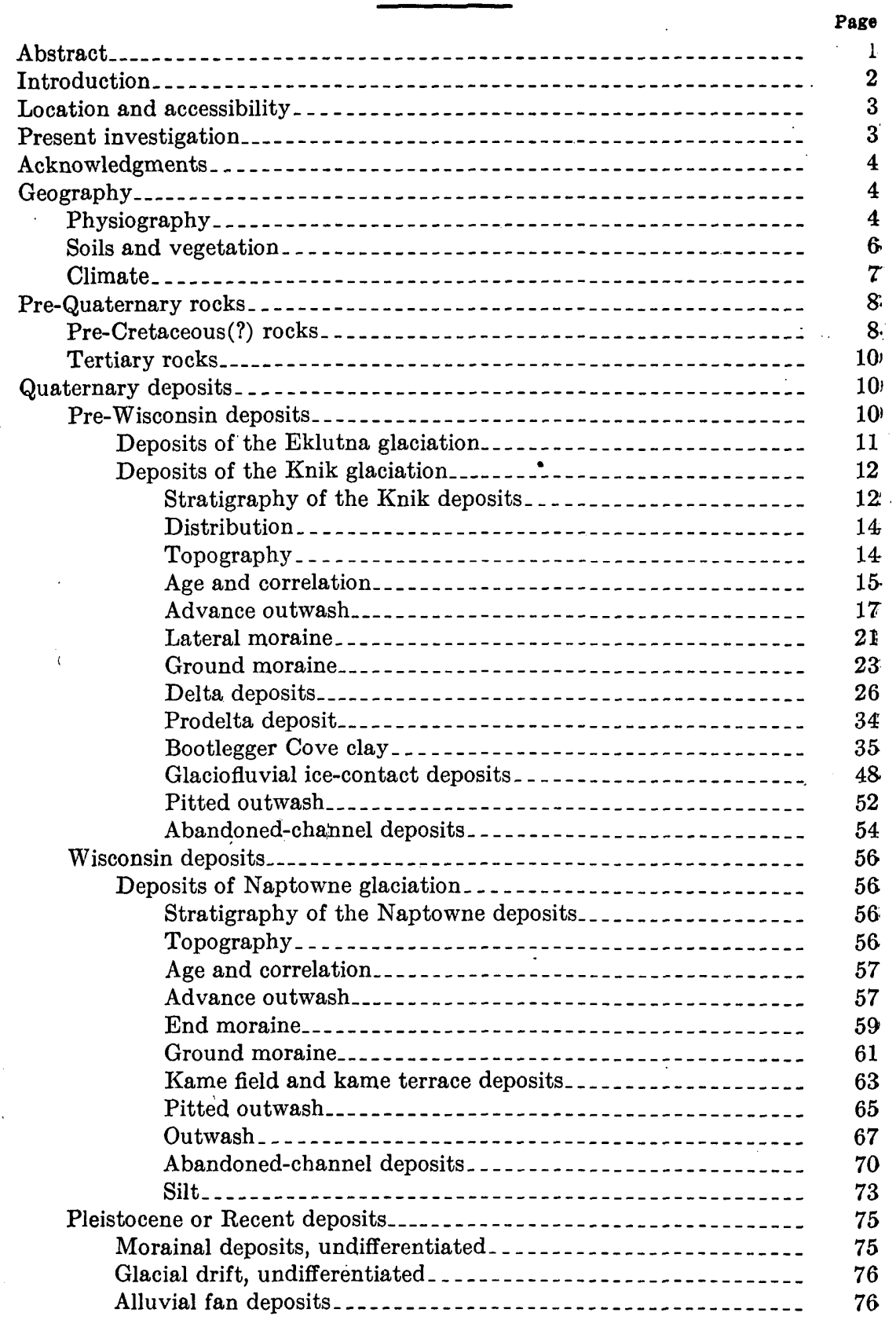


Quaternary deposits-Continued Page

Recent deposits

Swamp deposits .

Dune sand........ 80

Estuarine silt. .

Alluvium

Loess ...

Geologic history

Glacial history . .

Postglacial history

Economic geology _...

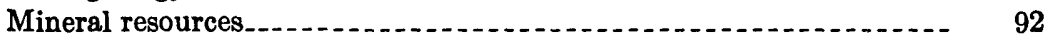

Coal

Limestone...

Peat. .

Marl_._.

Water.... 93

Construction materials..... 95

Brick clay .......

Riprap._.......... 95

Crushed aggregate..... 96

Sand and gravel....... 99

Fill

Ballast_...

Soil binder............. 99

Engineering problems.

Foundation conditions .

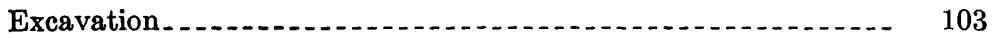

Slumps and flows._._. 103

Drainage........... 107

Frost heave...

Well logs cited in text..... 111

References cited

Index ...

\section{ILLUSTRATIONS}

[Plates $1-3,5,6$, and $\theta$ are in pocket]

Plate 1. Geologic map of Anchorage and vicinity, Alaska.

2. Perspective diagram showing physiographic setting of Anchorage, Alaska.

3. Interpretive sketch of glacial deposits along Knik Arm north of the Eagle River Flats.

4. $A$, Soled and striated greenstone boulder from till of Naptowne age. $B$, Delta deposits near Point Woronzof .......... Faces

5. Isometric diagram showing geology under part of the city of Anchorage, Alaska.

6. Isometric fence diagram showing the inferred extent of the Bootlegger Cove clay. 
Plate 7. $A$, Kame showing inclined bedding. $B$, Kame deposits showing folding and normal faulting of sand and gravel

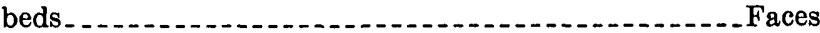

8. A, Abandoned-channel deposits overlying pebbly till.

$B$, Involutions in pitted outwash of Naptowne age....... Faces

9. Diagrammatic interpretation of the stratigraphic relationships between the Eklutna, Knik, and Naptowne deposits.

10. Slides and flows in Bootlegger Cove clay .............. Faces

Figure 1. Temperature and precipitation ranges at Anchorage, Alaska,

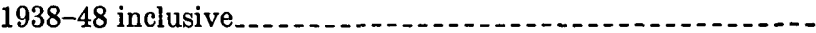

2. Tentative correlation of glacial events in the Anchorage area

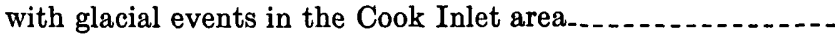

3. Comparative curves showing grain size of various clays.......

4. Erratic boulder in Bootlegger Cove clay . . .

5. Relationship of outwash of Naptowne age to till of ground

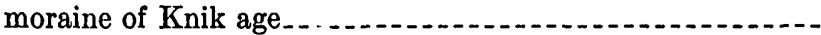

6. Positions of receding bluff line at Point Woronzof from 1909 to $1954 \ldots \ldots$

7. Diagrammatic sketch showing relationship of ground-water movement to upper surface of Bootlegger Cove clay .......

\section{TABLES}

TABLD 1. Stratigraphic column showing Quaternary deposits around

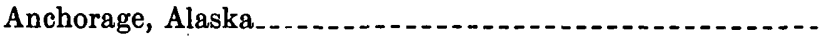

2. X-ray analyses of clay samples showing materials in silt and clay fractions of each sample.

3. Selected samples tested for various types of construction and

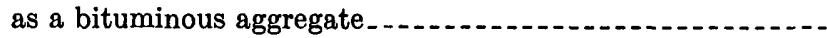

4. Percentage of rock types, as determined by pebble count, in abandoned-channel deposits near Goose Lake, and outwash, both of Naptowne age, and in prodelta deposits of Knik age.-

5. Mechanical analyses of selected samples......................

6. Records of earthquakes reported in Anchorage 1936-54_.....

7. Relative susceptibility of geologic units in the Anchorage area to frost action......... 



\title{
SURFIGIAL GEOLOGY OF ANGHORAGE AND VIGINITY, ALASKA
}

\author{
By Robert D. Muller and Ernest Dobrovolny
}

\section{ABSTRACT}

Anchorage and vicinity cover parts of three quadrangles, the Anchorage $\mathbf{A - 8}$, Anchorage $B-8$, and Tyonek $A-1$. Knik Arm bounds the area on the northwest, Turnagain Arm bounds the area on the south, and the Chugach Mountains bound the area on the east.

The highest point in the area is 4,301 feet above mean sea level, fust east of McHugh Peak in the southeastern part of the area. The altitude of the lowlands south of Anchorage ranges between 100 and 150 feet. Two areas of higher altitudes are the highland between Point Campbell and Point Woronzof where the altitude ranges between 150 and 300 feet, and the Elmendorf Moraine north of Anchorage where the altitude averages between 250 and 300 feet.

Argillite, graywacke, and chert, as well as altered acidic and basic igneous rocks, constitute the greater part of the pre-Cretaceous (?) rocks in the Anchorage area. Metamorphosed limestone crops out in several small areas along Turnagain Arm.

Surficial deposits in the Anchorage area are divisible into four main groups-pre-Wisconsin, Wisconsin, Pleistocene or Recent, and Recent. They represent deposits of at least 3 of the 5 glaciers that invaded the Anchorage area, as well as lacustrine and alluvial deposits consequent with or subsequent to the advances.

The oldest pre-Wisconsin deposits consist of till, outwash, and silt deposited by the Eklutna glacier, and are exposed only in one area north of the Eagle River Flats along the bluff of Knik Arm.

Sorted and unsorted drift of the youngest pre-Wisconsin glaciation, the Knik glaciation, form deposits of advance outwash, lateral moraine, ground moraine, pitted outwash, and glaciofluvial and ice-contact deposits. An extensive bluegray clay of lacustrine or estuarine origin, herein named the Bootlegger Cove clay, and delta and prodelta deposits of silt, sand, and gravel constitute ponded fluvial-lacustrine deposits. The Bootlegger Cove clay is extensive along Knik Arm where it separates the Knik from the overlying Naptowne glacial deposits. Alluvial deposits form the floor of abandoned melt-water channels in the ground moraine.

Sorted and unsorted drift of the glaciation of Wisconsin age, the Naptowne glaciation, form advance outwash, ground moraine, end moraine, ice-contact deposits separated into sequences of kame fields and kame terraces, outwash, and pitted outwash. Alluvial deposits cover the floor of abandoned melt-water channels that cut into Wisconsin deposits and into pre-Wisconsin deposits exposed south of the area covered by the Wisconsin deposits. Eolian silt prob- 
ably derived from the outwash of Wisconsin age covers older deposits in the vicinity of the International Airport.

Various undifferentiated glacial deposits as well as alluvial-fan deposits may be Pleistocene or Recent deposits. The undifferentiated morainal deposits and undifferentiated glacial drift, for the most part restricted to the mountain valleys and cirques, may include deposits that range from pre-Wisconsin to Recent in age. Certain alluvial fans were formed during the late Pleistocene, whereas others were formed during the Recent epoch. Deposits of unequivocal Recent age include peat and muskeg, which started to accumulate in swamps over 5,000 years ago and are still accumulating, dune sand, modern-channel and flood-plain alluvium, estuarine silt, and thin loess (not mapped) that blankets most other deposits.

Five glaciations are recognized in the Anchorage area; (1) the Mount Susitna glaciation that overrode Mount Susitna about 35 miles northwest of Anchorage and left scattered boulders on some of the high-level surfaces of the Chugach Mountains, (2) the Caribou Hills glaciation that smoothed the spurs of the Chugach Mountains at altitudes of about 2,200 to 2,800 feet east of Anchorage, (3) the Eklutna glaciation that covered the lowland in the Anchorage area, and (4) the Knik and Matanuska lobes of the Knik glaciation which covered the Anchorage area; a warmer interval is inferred from the environmental requirements of fossils in peat that separates the Knik glacial deposits from (5) deposits related to the Naptowne glacial advance of Wisconsin age. Fluctuation of the Naptowne glacier is suggested by till that overlies the Bootlegger Cove clay and underlies the Naptowne advance outwash and till of the Naptowne ground moraine, and by the presence of ice-contact features in the Wisconsin glacial deposits beyond the end moraine of the Wisconsin glacier.

The outwash on which Anchorage is built, and which flanks the south boundary of the end moraine, had its source in the Eagle River valley.

Age and depositional relationships of the moraines and other drift in the mountain valleys and cirques are not established.

Postglacial activities in the Anchorage area are confined mostly to erosionas represented by undercutting of sea-bluffs, landslides or slumps and flows, and downcutting into consolidated as well as unconsolidated materials along modern stream courses-and to eolian deposition-as represented by an overall thin cover of loess and by sand dunes.

Materials suitable for brick, for subbase course, base course, surfacing, and coarse aggregate, for crushed aggregate usable in bituminous mats, fill, and ballast, for soil binder, and for agricultural lime are found in the Anchorage area in varying amounts.

Foundation conditions range from excellent to poor. Some deposits are subject to varying degrees of frost heaving. In general, the finer grained till, silt, and glaciofluvial deposits are more susceptible to heaving than are coarser grained outwash and alluvial deposits.

\section{INTRODUCTION}

The Cook Inlet area was explored by Capt. James Cook in June 1778 when he sailed up what is today Cook Inlet. Portlock and Jeremiah Dixon visited Cook Inlet in 1786; George Vancouver explored Knik and Turnagain Arms in 1794.

Except for sporadic prospecting for gold (the first gold was mined in Alaska on the Kenai Peninsula in 1848-50) the Knik- 
Turnagain region aroused little interest until gold-bearing placer deposits were discovered south of Turnagain Arm at Anchor Point on the Kenai Peninsula. Between 1896 and 1898 many claims were staked along the north side of Turnagain Arm. W. C. Mendenhall, who was attached to an Army expedition in 1898, first mentioned the Knik-Turnagain Arm area in a U.S. Geological Survey publication (1900) but S. R. Capps $(1916,1940)$ made the earliest geological investigations around Anchorage. Martin (1906), Brooks (1906, 1923), Park (1933), Smith (1939), and Trainer (1953) described the geology of areas close to or in part overlapping the Anchorage area. Other reports that discuss the geology of the Anchorage area have been written by Karlstrom (1950) and by Péwé and others (1953).

Anchorage was founded in 1915 as a construction center for the Alaska Railroad. Today a modern city, Anchorage continues to undergo the most rapid expansion of any community in Alaska. Exceptional population growth and industrial activity since 1940 led to the selection in 1949 of the Anchorage area for geologic study.

\section{LOCATION AND ACCESSIBILITY}

The area mapped is bounded on the northwest by Knik Arm, on the south by Turnagain Arm, and on the east by the Chugach Mountains. The eastern boundary coincides with the $149^{\circ} 37^{\prime} 30^{\prime \prime}$ meridian. Almost all of the Anchorage $A-8$ quadrangle, all the area south of the Knik Arm in the $B-8$ quadrangle, and the land area in the Tyonek $A-1$ quadrangle between Point Woronzof and Point Campbell are within the project.

Anchorage is served by the Alaska Railroad and by scheduled and charter airlines at the International Airport and Merrill Field. The principal paved highways traversing the area are the Glenn Highway extending north from Anchorage and the SewardAnchorage Highway extending south. Most of the maintained roads are graveled. Industrial and urban expansion is rapidly extending outward from Anchorage, and newly (1956) constructed section-line and homestead roads continuously increase accessibility. Much of the area north of the Eagle River and in the mountain area is reached by trail or jeep road.

\section{PRESENT INVESTIGATION}

In the summer of 1949 surficial deposits were examined along roads, streams, excavations, and sea cliffs, and in traverses throughout most of the lowland. Reconnaissance traverses were made along the front of the Chugach Mountain Range, along bedrock ridges, along Potter, Little Rabbit, Rabbit, Campbell, North Fork 
of Campbell, and Ship Creeks, in the eastern part of the area, and along the Eagle. River in the northern part of the area. A brief description of the geology was released to open file in 1950 (Dobrovolny and Miller). In June 1954, the area was revisited briefly by R. D. Miller and J. M. Cattermole. Fieldwork was confined mostly to studying road cuts that had been excavated since 1949 ; additional well records were also obtained. In 1956, the authors and W. R. Hansen checked the map and geologic interpretation in the field.

Stereoscopic examination of aerial photographs helped to supplement field interpretation of physiography and geology. Photointerpretation was most useful in the mountain area and in the lowland near Eagle Bay where ground traverses were limited by lack of roads, marshy terrain, and artillery ranges.

\section{ACKNOWLEDGMENTS}

Personnel of many Federal and Territorial agencies were considerate and helpful in providing data for use in the report or providing facilities to prepare data.

Mr. Harold Jorgensen of the Bureau of Land Management loaned a set of aerial photographs and rendered other service. $\mathrm{Mr}$. N. E. Nelson, construction engineer, Civil Aeronautics Administration, provided test data and use of a materials laboratory. Mr. John J. O'Shea, assayer, Territorial Bureau of Mines, made several insoluble-residue tests on limestone. Mr. W. A. Nieme, district engineer, Alaska Road Commission (1949), supplied materials test data. Col. Lyle E. Seeman (1949), of the U.S. Army Corps of Engineers, Mr. A. A. Theuer (1949), and Mr. J. A. Roy (1954), of the U.S. District Engineers, provided materials test data and water-well records. Mr. W. R. Judd, engineering geologist, U.S. Bureau of Reclamation, provided a sample of clay from Lake Eklutna for testing. Mr. L. G. Anderson, U.S. Bureau of Mines, provided office space and many reference publications.

In addition, special thanks is due T. N. V. Karlstrom, U.S. Geological Survey, Terrain and Permafrost Section, who during a 2-day field conference contributed many ideas and suggestions, as well as thought-provoking concepts of the regional geologic picture.

\section{GEOGRAPHY}

\section{PHYSIOGRAPHY}

The Anchorage area, as mapped in this report (pl. 1), includes the greater part of the Anchorage district of the Cook Inlet region (Smith, 1939, pl. 3). Plate 2 shows the physiographic relationship. 
of the Anchorage area to the Cook Inlet lowlands and the adjacent mountain valleys. The Anchorage area can be separated into lowlands, which cover most of the area, and mountains along the eastern boundary of the area. The lowlands in turn, can be separated into six smaller subdivisions: (1) smooth surfaced elongate hills and linear valleys that modify the pitted surface north of the Elmendorf Moraine, (2) the southwest-trending ridges that form the Elmendorf Moraine, (3) a broad surface of a sand and gravel plain that is parallel to and southwest of the Elmendorf Moraine, (4) broad swamps which cover the lowland south of Anchorage, modified by conical and rounded mounds and low sinuous hills, (5) a low hummocky terrain that extends from the boundary with the swamp area just west of the Seward to Anchorage Highway to the mountains, and (6) the Point Woronzof and Point Campbell highland that extends along the western boundary.

The highest point in the area is a peak slightly more than 4,500 feet above sea level on the ridge between Rabbit Creek and South Fork Campbell Creek. The lowlands range between 100 and 150 feet in altitude. The valleys of the mountain mass are U-shaped and the steep intervening ridges are almost barren of mantle rock.

Surface drainage of the area is moderately well developed. Along the mountain front low south-trending elongate ridges 1 to 3 miles long control the orientation of small streams except where the streams turn and flow westward through gaps. Eagle River, Ship, and Chester Creeks follow old melt-water channels. Campbell Creek, the longest stream in the lowlands south of Anchorage, originates in a glaciated mountain valley. It flows in a deeply incised meltwater channel to the lowlands where it meanders through swamps. Streams that cascade from the high valleys of the Chugach Mountains are entrenched as much as 110 feet into unconsolidated glacial deposits on the slopes of the mountain front; in places they flow in steep-walled bedrock gorges almost 150 feet deep.

Drainage is poorly integrated in the swamps south of Anchorage. Many lakes in the swamps are connected by small sluggish streams. Some swamps are undrained, such as those in secs. 32 and 33, T. 13 N., R. 3 W., even though Campbell Creek and other streams have cut channels more than 5 feet below swamp level.

Subsurface drainage in the lowlands is poor because the clayey till that underlies much of the area is relatively impervious and restricts downward movement of the water. For that same reason; small swamps are common on hill tops.

Drainage is even less developed in the area north of the Elmendorf Moraine than in the lowlands south of Anchorage. Along broad melt-water channels small consequent streams connect swamps, 
ponds, and lakes. Elsewhere most of the lakes and ponds in the ground moraine are poorly drained.

\section{SOILS AND VEGETATION}

The soils in the Cook Inlet area around Anchorage are podzol soils. The process of podzolization and characteristic profiles of podzol soils are described by Wilde (1946), Joffe (1949), and others. Well developed podzol soils are typified by an ash-gray colored zone in the $\mathrm{A}_{2}$ horizon (the podzol horizon) that results from leaching of the soluble salts and organic matter. Leaching intense enough to remove the iron compounds causes a light color in the horizon; extreme leaching causes the white ashy appearance. The Russian word "zola," meaning ash, is the root of the name podzol. Podzol soils develop in coniferous, deciduous, or mixed forests in cool-temperate climates. Soils of the Knik series, of which the Knik loam is representative, are most extensive in the lowland (U.S. Dept. of Agr., 1938, p. 1148). A characteristic podzol soil profile on the Naptowne outwash along the Spenard Lake road 11/2 miles south of Anchorage was measured by Kellogg and Nygard (1951, no. 48, p. 52 ), as follows:

\section{Podzol}

$A_{0}-0$ to $2 \frac{1}{2}$ inches, very dark brown fibrous organic mat containing many woody roots.

$A_{1}-0$ to $1 / 4$ inch, dark-brown to black humus soll.

$A_{2}-1 / 4$ to 3 inches, light-gray to reddish-gray friable fine sandy loam, specked with yellowish brown; weakly developed fine platy structure; many roots. (Light gray: $5 \quad 7$ 7/1.)

$B_{2}-3$ to 10 inches, yellowish-brown fine sandy loam containing many roots. The soll is weakly cemented and, in places, contains strongly cemented fragments of ortstein.2 (10 $Y R$ 5/6.)

$B_{3}-10$ to 14 inches, light-yellowish-brown friable fine sandy loam; very few roots. $(10 \mathrm{YR} 6 / 4$.)

C-14 inchest, loose fine and medium sands of mixed composition, but high in dark-colored minerals.

Most of the biological processes that enter into soil formation are limited to the upper 6 to 18 inches, so that the soils are said to have a shallow solum (Kellogg and Nygard, 1951, p. 125). Podzolization is moderate, so that the ashy-colored layers are not well developed everywhere.

Muskegs and marshes on the Knik soils consist more or less of decomposed brown peat. Much of the peat is made up of sphagnum moss.

\footnotetext{
1 Color names and designations refer to the Rock Color Chart of the National Research Council, 1948.

2 "Ortstein is a form of concretion that consists primarily of soll particles cemented with iron, aluminum, manganese, humus substances * * *" (Joffe, 1949, p. 56.)
} 


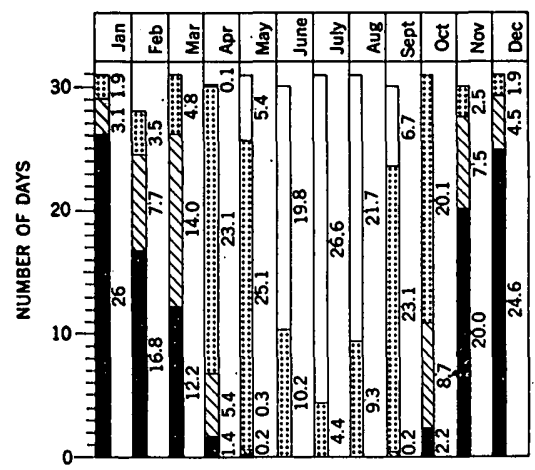

A

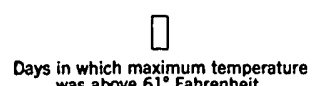
was above $61^{\circ}$ Fahrenheit

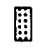

Days in which maximum temperature Days in which maximum temperatur
was between $41-60^{\circ}$ Fahrenheit

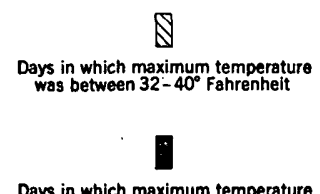

ays in which maximum temperatur was less than $32^{\circ}$ Fahrenheit

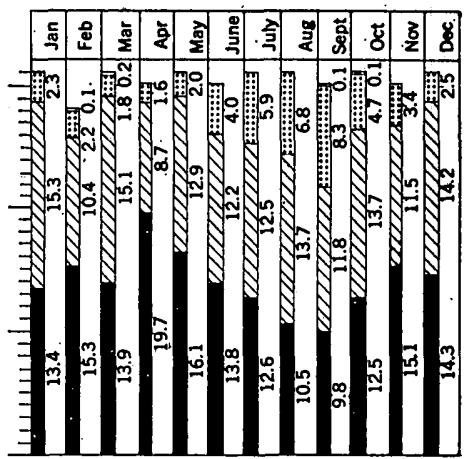

B

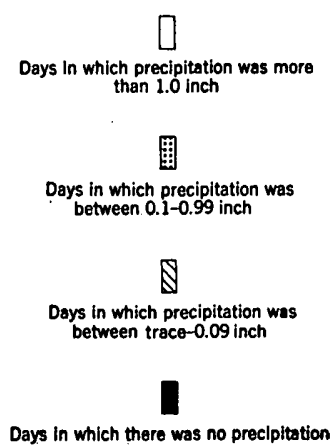

Days in which there was no preclpitation

Compiled from climatological

data, issued by the Weather

of Commerce, Anchorage.

FIGORE 1.-Temperature and precipitation ranges at Anchorage, Alaska, 1938-48 Inclugive. Compiled from climatological data, Issued by the Weather Bureau, U.S. Department of Commerce, Anchorage, Alaska, for the years 1938-48 inclusive.

\section{CLIMATE}

Anchorage is influenced more by the comparatively mild humid climate of the Gulf of Alaska than by the colder climate of the region north of the Alaska Range. Figure 1, compiled from the Weather Bureau files, shows the period 1938 to 1948 inclusive. Temperature and precipitation are factors that control certain aspects of construction activities such as excavation, laying bituminous mats, and setting concrete.

Anchorage has a normal ${ }^{3}$ annual precipitation of 14.27 inches. The normal of the wettest month is 2.71 inches, with an extreme of 5.91 inches. (U.S. Weather Bureau, 1954, p. 36.)

The mean annual temperature is $35.3^{\circ} \mathrm{F}$. The highest temperature recorded in a 31 year period was $86^{\circ} \mathrm{F}$ and the lowest was $-38^{\circ} \mathrm{F}$. 
The prevailing wind is about 5 miles per hour. It blows from the northeast in winter, the north in the spring, the northwest in summer, and from the north in the fall.

\section{PRE-QUATERNARY ROCKS}

The mountains bordering the Anchorage lowlands on the east are composed of consolidated metamorphic rocks of pre-Cretaceous(?) age. Poorly consolidated rocks of Tertiary age, exposed in a few places in the lowland, are thought to underlie most of the lowland. Unconsolidated deposits of Quaternary age effectively bury all older rocks in the lowland and mantle parts of the lower slopes of the mountains and some mountain valleys.

\section{PRE-CRETACEOUS(?) ROCKS}

The rocks that form the Chugach Mountains in the southeastern part of the area are grouped as metamorphic rocks, undifferentiated (pKg). The present investigation touched but briefly upon areas containing rocks older than Pleistocene, and discussion of the older rocks is for the most part confined to a resumé of previous work. Most of these rocks are described in detail by Capps $(1916,1940)$ and Park (1933). According to Park (1933, p. 389) they are of pre-Cretaceous age, and are so considered in this report.

Capps (1916, p. 153) restricted the undifferentiated metamorphic rocks in the Knik-Turnagain area to a belt along the western edge of the Chugach Mountains. The rocks are found in all or parts of the mountainous basins of Campbell, Rabbit, Chester, and Ship Creeks.

Capps (1916, p. 153) identified $6 * * *$ basic intrusive rocks, locally altered to serpentines, and altered intrusive rocks of more acidic character, associated with much altered and crushed materials that are probably of sedimentary origin and some less altered slates."

In addition, Capps (1916, p. 154) described " $* * *$ altered igneous rocks of acidic composition that under the microscope prove to be altered andesites and andesite porphyries and basic rocks consisting of peridotite, dunite, serpentine, pyroxenite, altered gabbros, and tuff and agglomerates of igneous origin. They also include altered argillites, graywackes, and cherts of sedimentary origin. This whole assemblage has been cut by both basic and acidic dikes and probably by the bosses of diorite that project through the unconsolidated deposits near the mouth of Knik River." Park (1933, p. 388) agreed with Capps as to the types and composition of the rocks.

On the South Fork of Campbell Creek the bedrock consists of graywacke, quartzite, and some greenstone with gray chert bands 
and nodules. The graywacke is easily recognized; it consists of angular fragments of quartz, feldspar, and other minerals.

Metamorphosed limestone (pKl) is exposed in three places, in a large outcrop along Little Rabbit Creek, and in two outcrops south of Little Rabbit Creek along the Seward-Anchorage Highway. An outcrop a quarter of a mile south of Little Rabbit Creek was examined in detail. The limestone outcrop is approximately 40 feet wide and 25 feet high; it is. separated on the north from the undifferentiated metamorphic rocks by a fault striking N. $22^{\circ}$ E. and dipping $62^{\circ} \mathrm{W}$. Its contact with the undifferentiated metamorphic rocks on the south is concealed by till 50 to 100 feet thick; the gradeline of the highway is about 70 feet above the top of the limestone outcrop. This limestone contains 4.2 percent residue insoluble in hydrochloric acid, or 95.8 percent $\mathrm{CaCO}_{3}{ }^{4}$

Limestone crops out for about one-fourth mile along Little Rabbit Creek from a point about 300 feet upstream from the Seward to Anchorage highway. The limestone is impure and contains iron. Three hundred feet upstream shattered limestone and graywacke that dips about $80^{\circ} \mathrm{NW}$. extends for 60 feet at stream level. A shear zone strikes N. $45^{\circ}$ E. and dips $65^{\circ} \mathrm{W}$.

The exposures along Little Rabbit Creek are discontinuous; threefourths of a mile upstream the limestone is interbedded with graywacke and constitutes only a small percentage of the rock.

Three samples of limestone collected about 300 feet upstream from the highway bridge over Little Rabbit Creek range from 51.1 to 64.0 percent residue insoluble in hydrochloric acid.

The age of the undifferentiated metamorphic rocks and limestone is established relative to other rocks. The argillites and graywackes, east of the undifferentiated metamorphic rocks, and east of the area mapped, are dated by fragments and imprints of Inoceramus sp. believed to be of Late Cretaceous age (Park, 1933, p. 393-394). Capps (1916, p. 155) considered the undifferentiated metamorphic rocks to lie unconformably below the argillites and graywackes and to be older than late Mesozoic. Parks (1933, p. 389) considered the undifferentiated metamorphic rocks to be of probable pre-Cretaceous age even though the deformation at their contact with the argillites and graywackes is so severe that the relationships between the two units are difficult to establish. Although it could not be determined which rock unit overlies the other, Park considers the undifferentiated metamorphic rocks to be older because of their more intense deformation and greater igneous intrusion. Payne (1955) shows Triassic and Jurassic rocks of the Seldovia geanticline extending

4 Analyzed by John J. O'Shea, assayer, Territorial Bureau of Mines, Anchorage, Alaska. 
through the Anchorage area and apparently including the rocks below the argillites and graywackes.

\section{TERTIARY ROCKS}

Rocks of Tertiary age are not exposed in the area mapped, but they crop out just east of the area along the Eagle River between the Alaska Railroad bridge and the bridge on the Glenn Highway (Capps, 1940; Dobrovolny and Miller, 1950). Records of wells near the Power Plant in Fort Richardson, near center of sec. 6, T. 13 N., R. 2 W., at the Fire Control Station, sec. 11, T. 13 N., R. 3 W., and at the West Power Plant well, sec. 8, T. 13 N., R. 3 W., indicate the upper surface of the Tertiary rocks to be at depths of about 230 feet, 447 feet and 776 feet, respectively (U.S.G.S. No. 10, Ski Bowl Road, Corps of Engineers, written communication February 1957; Cederstrom and Trainer, 1953, Well No. 173; U.S. Corps of Engineers, unpublished well record, West Power Plant well). The beds at the abandoned coal mine near the Alaska Railroad bridge over the Eagle River strike N. $10^{\circ}$ E. and dip $8^{\circ}$ W. This compares with dips of about $2^{\circ}$ to $4^{\circ}$, with local maxima of $10^{\circ}$ to $13^{\circ}$, reported elsewhere (Capps, 1940, p. 62). Such gentle dips could not alone account for a 700 foot depth to the top of the Tertiary rocks from the surface outcrops. Eardley (1951, p. 523) mentions some orogenic movements in late Pliocene or Pleistocene time. R. G. Gastil ${ }^{5}$ (Corps of Engineers, unpublished maps) infers a fault between the surface outcrops and the well locations.

Coal beds, relatively common in the Tertiary rocks, are commercially exploited north of the mapped area along the Matanuska River valley. Once, coal was mined along the Eagle River near the Alaska Railroad bridge, but the workings are now abandoned. No deposits of coal are known along Turnagain Arm, or within the mapped area. Coal seams at or near Point Campbell, reported by Martin (1906, p. 25), and coal ledges at Point Woronzof, reported by Capps $(1940$, p. 62$)$, proved to be reworked material. Blocks of fluvially transported coal 6 feet long were found partly buried by tidal silts at Point Woronzof. Layers of fluvial coal with blocks as much as 8 inches in diameter were interbedded with gravel, sand, and silt layers at Point Campbell. Coal in seams was not found.

\section{QUATERNARY DEPOSITS}

\section{PRE-WISCONSIN DEPOSITS}

According to Karlstrom (1957) five major glacial advances can be recognized in the Cook Inlet region. Although the 2 earliest

5 Corps of Engineers, 535th Terrain Detachment, written communication August 31, 1956. 
glaciations may have caused smoothing of spurs in the Anchorage area, deposits of only the last 3 glaciations have been recognized. The oldest glaciation recognized by Karlstrom is the Mount Susitna glaciation, and is based on rounding of summits and spurs at altitudes up to 4,400 feet above sea level on Mount Susitna, a mountain 34 miles northwest of Anchorage, and at other places within the Cook Inlet area (Karlstrom, in Péwé, and others, 1953, p. 3). The second oldest glaciation recognized by Karlstrom (in Péwé, and others, 1953, p. 4) is the Caribou Hills glaciation (Krinsley, in Péwé, and others, 1953, p. 5), represented by glacial deposits at altitudes of 3,000 feet near Tustumena Lake, 75 miles S. $15^{\circ} \mathrm{W}$. of Anchorage. Smoothed spurs and ridges at altitudes of about 2,200 to 2,800 feet along the front of the Chugach Mountains east of Anchorage, may be the result of the Caribou Hills glaciation. The oldest glacial deposits mapped in the Anchorage area are products of the Eklutna glaciation of Karlstrom (1957, p. 74) and are exposed as till and outwash in the bluffs along Knik Arm north of the Eagle River Flats (table 1).

\section{DEPOSITS OF THE EKLUTNA gLaCIATION}

The oldest glacial deposits mapped in the Anchorage area are till and outwash exposed in the bluffs along Knik Arm north of the Eagle River Flats. The lowermost till is olive tan in color. It abuts to the south against a contorted silt which in turn grades into gravel (pl. 3). The upper surfaces of the lowermost till, silt, and gravel, are truncated by an erosional surface that extends across these materials. Forty feet of silt and gravel constitute the lower two-fifths of the bluff in the SE $1 / 4$ sec. 18 , T. 15 N., R. 2 W. (pl. 3, observation point 8 ). The gravel continues around the point almost to the Eagle River Flats. A cobble layer in the unconformably overlying outwash and a vertical break in slope almost everywhere mark the upper limit of the silt and gravel. The lowermost till was deposited by a glacier that covered the lowland area. The silt and gravel abutting the till and extending southward probably are outwash of the same glaciation. Examination of isolated exposures along the east side of Knik Arm merely suggests the possible antiquity of the deposits: they may correspond with a deposit of contorted buff-colored silt, sand, and gravel, also oxidized over 40 feet in depth, that is exposed beyond Point MacKenzie on the west side of Knik Arm (Karlstrom, oral communication July 1956).

Because the till, silt, and gravel are oxidized throughout their exposed thickness, indicating a long period of weathering, because they are the lowermost deposits in the bluff, because they have an eroded surface that extends across all three materials, and because they are overlain by a younger pre-Wisconsin till and outwash, they 
are correlated tentatively with Karlstrom's Eklutna glaciation of Illinoian(?) age (1957, p. 73). (See fig. 2.)

TABLE 1.-Stratigraphic column showing Quaternary deposits around Anchorage, Alaska

\begin{tabular}{|c|c|c|c|}
\hline Series & Stage & Glaciation & Geologic units \\
\hline Recent & & & $\begin{array}{l}\text { Loess (not mapped) } \\
\text { Alluvium } \\
\text { Estuarine silt } \\
\text { Dune sand } \\
\text { Swamp deposits }\end{array}$ \\
\hline $\begin{array}{l}\text { Pleistocene } \\
\text { or Recent }\end{array}$ & & & $\begin{array}{l}\text { Alluvial fan deposits } \\
\text { Glacial drift, undifferentiated } \\
\text { Morainal deposits, undifferentiated }\end{array}$ \\
\hline \multirow{3}{*}{ Pleistocene } & Wisconsin & Naptowne & $\begin{array}{l}\text { Silt } \\
\text { Abandoned-channel deposits } \\
\text { Outwash } \\
\text { Pitted outwash } \\
\text { Kame field and kame terrace de- } \\
\quad \text { posits } \\
\text { Ground moraine } \\
\text { End moraine } \\
\text { Advance outwash }\end{array}$ \\
\hline & \multirow[t]{2}{*}{ Pre-Wisconsin } & Knik & $\begin{array}{l}\text { Abandoned-channel deposits } \\
\text { Pitted outwash } \\
\text { Glaciofluvial ice-contact deposits } \\
\text { Bootlegger Cove clay } \\
\text { Prodelta deposits } \\
\text { Delta deposits } \\
\text { Ground moraine } \\
\text { Lateral moraine } \\
\text { Advance outwash }\end{array}$ \\
\hline & & Eklutna & Till and outwash \\
\hline
\end{tabular}

\section{DEPOSITS OF THE KNIK GLACIATION}

\section{STRATIGRAPHY OF THE KNIK DEPOSITS}

The advance outwash is the oldest deposit of the Knik glacier in the area. The lateral moraine along the front of the Chugach Mountains grades westward into the ground moraine that underlies most of the lowland. The glaciofluvial ice-contact deposits, the prodelta deposits, the pitted outwash deposits, and the Bootlegger Cove clay all overlie the ground moraine locally. The delta is at least in part contemporaneous with the Bootlegger Cove clay. The alluvium in the abandoned melt-water channels also overlies the ground moraine, but was deposited at the later phase of the Knik glaciation. 
The following genetic relationship of the Knik deposits preclude the possibility that the ground moraine of the Knik glaciation and the overlying stratified drift are deposits of two different glacial stages: 1 , the boundary between the glaciofluvial ice-contact deposits south of Ship Creek and the lateral moraine is gradational, as is the contact between the lateral moraine and the ground moraine; 2 ,

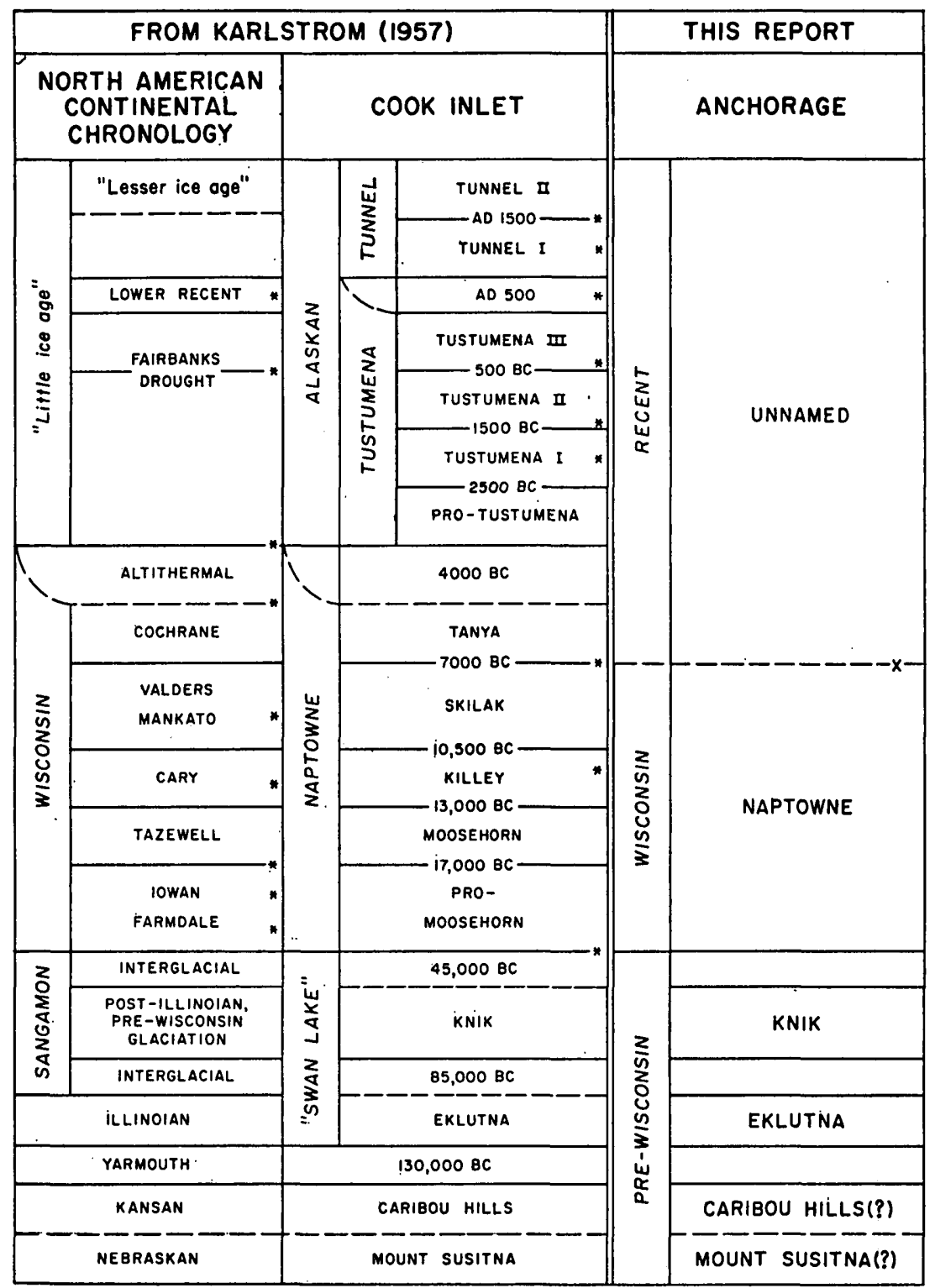

* $\mathrm{C}^{14}$ rodiocarbon dates

$x$ Wisconsin and post-Wisconsin boundary from Deevey and Flint, 1957

Figdre 2.-Tentative correlation of glacial events in the Anchorage area with glacial events in the Cook Inlet area as determined by T. N. V. Karlstrom. 
surface expression, weathering, and the texture of the materials are similar in both morainal deposits; 3 , the glaciofluvial ice-contact deposits and pitted outwash, which locally overlie these moraines, are cut by abandoned melt-water channels that also head in and are incised into Knik ground moraine.

The Bootlegger Cove clay separates the pre-Wisconsin Knik deposits from the overlying Wisconsin Naptowne deposits on the east side of Knik Arm. The Bootlegger Cove clay is considered to be a glacial deposit that shows interglacial weathering. Its upper 6 inches to 2 feet is oxidized. Till and the advance outwash of the Knik glacier overlie the truncated surface of the Eklutna till and outwash along Knik Arm north of the Eagle River Flats. The Bootlegger Cove clay locally separates the till of the Knik ground moraine from the Wisconsin deposits.

\section{DISTRIBUTION}

Pre-Wisconsin deposits underlie the lowland south of Anchorage and extend along the Chugach Mountain front. The Knik ground moraine underlies the lowland and the stratified deposits locally blanket the older ground moraine. The highland between Point Woronzof and Point Campbell is composed of delta deposits that at least in part are contemporaneous with the Bootlegger Cove clay. North of the Elmendorf Moraine the Knik deposits are exposed only along the bluff of Knik Arm and near the mouth of the Eagle River.

\section{TOPOGRAPHY}

The topography of the pre-Wisconsin glacial deposits of the lowland has been only slightly more modified by erosion than the topography of the Wisconsin glacial deposits; drainage still is poorly integrated. In the Knik stratified deposits, swamp-filled kettles more than 1 mile in diameter are bounded by steep icecontact slopes. Overlying the ground moraine are almost completely unmodified kames and eskers of the Knik glaciation. On the slopes of the mountains, especially between O'Malley Road and Potter, the topography of the ground moraine is sharp and well defined. Erratic boulders locally cover the surface. Glaciofluvial ice-contact deposits, such as the kames and eskers along the mountains south of Ship Creek, and other stratified drift genetically related to the Knik ground moraine have well preserved, very youthful, topographic forms. At the junction of O'Malley Road and the SewardAnchorage Highway an exceptionally large kame shows steep, smooth slopes unmodified by erosion (pl. 7). The lateral moraine also has youthful kettles, ridges, and knobs.

In the pre-Wisconsin pitted outwash and prodelta deposits, steep ice-contact slopes bound the large kettles in the lowland. The 
topography of the older delta is distinct and relatively unmodified. Kettles, for the most part unfilled with debris, and abandoned meltwater channels have steep smooth slopes.

\section{AGE AND CORRELATION}

The pre-Wisconsin deposits in the lowlands are probably correlative with the Swan Lake deposits of Krinsley (in Péwé, and others, 1953, p. 5). He gave the name Swan Lake to moraines in the southwest part of the Kenai Peninsula that consist of

* * low, rounded hills, partly buried by outwash. Some kettle lakes stlll persist, but many of the original depressions are filled with peat and organic silt.

Karlstrom (in Péwé, and others, 1953, p. 4) describes the drift of the Swan Lake glaciation in the upper Cook Inlet as retaining-

* its hummocky aspect, but kettle depressions are partly filled with an intermixture of organic silt and peat.

These descriptions fit the older glacial deposits in the lowland south of Anchorage. Karlstrom's correlation of 1955 and 1957 subdivides the Swan Lake into the Eklutna deposits of Illinoian(?) age, and the Knik deposits of post-Illinoian, pre-Wisconsin age (fig. 2).

Near Goose Bay, almost directly across Knik Arm from the Eagle River Flats, a 41-inch interglacial peat bed underlies till and stratified sand and gravel that Karlstrom considers to be representative of his Naptowne glaciation (oral communication, July 1956). The peat bed appears to occur at the same stratigraphic horizon as the Bootlegger Cove clay, and the peat may correlate with the weathering on the clay. In 1955 , wood collected by T. N. V. Karlstrom from the upper 6 inches of this peat bed was dated as older than 38,000 radiocarbon years (Rubin and Suess, 1955, W-174, p. 486). The carbon-14 methods of radiocarbon determinations are discussed by Kulp, J. L. (1952), and Flint, R. F., and Rubin, Meyer (1955). Earlier radiocarbon dates for the same horizon but determined by different procedures are $19,100 \pm 600$ years (Kulp, and others, 1952, L-117 A, p. 412-413) and greater than 32,000 radiocarbon years for wood collected by Karlstrom from the base of the 41-inch peat section (Suess, 1954, W-77, p. 471). The greater than 38,000 radiocarbon years date indicates that the peat bed near Goose Bay may be older than the earliest radiocarbon dated Wisconsin age in the central United States (Flint and Rubin, 1955, p. 649 ), but this does not necessarily make it as old as Sangamon or Illinoian. Karlstrom (1955, p. 1581) considers the Wisconsin glaciation in the Cook Inlet region to range in age from 5,450 to 46,950 radiocarbon years. In July 1956 Karlstrom (oral communication) considered the till underlying the peat to be a deposit of his Knik glaciation (Rubin and Suess, 1956, W-294, p. 444; Karlstrom, 1957). 
A peat bed exposed along the Eagle River on the east side of the Knik Arm underlies the Wisconsin ground moraine and advance outwash, and overlies gravel of the pre-Wisconsin advance outwash. Sampled by the authors in 1949 , the peat was dated at $14,300 \pm 600$ radiocarbon years (Kulp, and others, 1951, 101B, p. 568). Resampled by the authors and W. R. Hansen in 1956, the peat bed was dated at greater than 38,000 radiocarbon years $(W-535)$. On the basis of this radiocarbon date and the similar sequence of the Goose Bay section, the deposits below the peat bed are correlated with Karlstrom's Knik glaciation (fig. 2).

The pre-Wisconsin glacial deposits south of the Wisconsin end moraine show weathering profiles that extend 4 to 8 feet in depth in the till of the ground moraine and 4 to 12 feet in depth on the lateral moraine; however, most exposures are oxidized only about 5 feet. Pre-Wisconsin stratified drift in the lowlands, although of greater permeability, shows a similar degree of weathering that extends locally only slightly more than 6 feet. This is in contrast with the oxidation throughout the 40-foot-thick Eklutna drift of Illinoian(?) age exposed along the bluff of Knik Arm north of the Eagle River Flats, and the oxidation of about 2 to 3 feet common on the Wisconsin drift.

Estimated ages for the Sangamon and Illinoian stages vary, but nevertheless indicate considerable time available for post-Illinoian weathering and erosion. Kay (1931, p. 464) suggested, on the basis of depths of leaching, that the Sangamon lasted about 120,000 years and ended about 75,000 years ago. One of the more recent estimates (Hough, 1953, fig. 2) dates the Illinoian as ranging from 338,000 years ago until 268,000 years ago, and the Sangamon as ranging from 268,000 years ago until 64,000 years ago. Suess (1956, p. 357 ) stated that a warm period about 90,000 years ago may correlate with the Sangamon of North America. Emiliani (1955, table 15, p. 565) suggests that the Sangamon ended about 75,000 years ago, the Illinoian started about 125,000 years ago and ended about 103,000 years ago.

The pre-Wisconsin glacial deposits south of Anchorage have a youthful topography typified by well-defined ridges, smooth and undissected slopes, and poorly integrated drainage. The weathering profile on the glacial deposits is immature in comparison to the weathering profile on the Eklutna drift (Illinoian? age) exposed north of Anchorage. It seems reasonable that deposits of 64,000 to 103,000 years old would be more deeply weathered, as is the drift of the Eklutna glaciation north of Anchorage, and the topography modified during the ensuing long interval of weathering and erosion than are the pre-Wisconsin deposits south of Anchorage. For these reasons the pre-Wisconsin deposits south of Anchorage are considered part of the Knik glaciation (table 1). 
The stratified drift that directly underlies till of the ground moraine deposited by the Knik glacier north of the Eagle River Flats and along Turnagain Arm is considered by the authors to be an outwash that was deposited in front of and subsequently overridden by the advancing Knik glacier. To some workers the term proglacial, as applied to deposits, means those that were deposited in advance of, or in front of, an advancing glacier, whereas to other workers, it means those that were laid down merely in front of a glacier, regardless of either the amount or direction of glacial movement. To avoid possible confusion by use of the word proglacial, and yet to separate this type of outwash from other outwashes related to the same glaciation, the term advance outwash is used in this report for such deposits. The advance outwash extends northward from the Eagle River Flats along the bluffs on the east side of Knik Arm to the boundary of the area mapped. Cuts along the Alaska Railroad, in the bluff along Turnagain Arm, show stratified sand and gravel below till of the ground moraine. Exposed from near Rabbit Creek northward for only about 11/4 miles, the sand and gravel probably extends farther along Turnagain Arm.

The advance outwash is gray and unoxidized where it underlies the till of the ground moraine. Locally hard and compact along Knik Arm, the advance outwash is predominantly a moderately loose pebble to cobble gravel that contains alternating layers of gray medium to coarse sand and pebble gravel. Lenses and layers of coal fragments are common. Along Knik Arm, near to and south of the promontory north of the Eagle River Flats, the bluff is composed of stratified drift of three ages; outwash of the preWisconsin Eklutna glaciation, advance outwash of the pre-Wisconsin Knik glaciation, and advance outwash of the Wisconsin Naptowne glaciation. A horizontal parting marked by a cobble layer separates the advance outwash from the overlying Naptown $\theta$ advance outwash. A similar cobble layer separates the Knik advance outwash from the underlying Eklutna outwash. This relationship is best seen in the NW1/4 SW $1 / 4$ sec. 19, T. $15 \mathrm{~N}$., R. $2 \mathrm{~W}$.

Along the east shore of Knik Arm, the exposed thickness of the advance outwash is generally about 15 feet. The maximum exposed thickness is about 30 feet. Along Turnagain Arm, the maximum exposed thickness is about 40 feet near Rabbit Creek. The advance outwash is partly concealed by the grade of the Alaska Railroad that climbs the bluff westward along the Arm. Examination of the gray stratified sand and pebble gravel that constitutes the Knik: advance outwash beneath the ground moraine along Turnagain Arm. 
failed to reveal any coal fragments either in lenses, layers, or scattered throughout the deposit as individual grains. Deposits of stratified drift exposed in Turnagain Arm were checked almost to the town of Portage (out of the area) without finding any coal fragments. Coal deposits underlie the Susitna Valley, the Matanuska Valley area, and at depth the Anchorage lowland, and are the source areas of the coal fragments in the glacial deposits around Anchorage. The advance outwash along Turnagain Arm, which contains no coal, came from a glacier in Turnagain Arm.

A silt layer (unit 4, measured section 1) associated with the peat that overlies the Knik advance outwash in the $\mathrm{SW} 1 / 4 \mathrm{SE} 1 / 4$ sec. 9, T. 14 N., R. 2 W.-dated as greater than 38,000 radiocarbon years (Meyer Rubin, U.S. Geological Survey, sample No. W535)—contains the fresh water gastropods Gyrautus parvus (Say) and Lymnea sp., identified by F. Stearns MacNeil, of the Geological Survey, and 14 genera of diatoms, identified by Kenneth E. Lohman, of the Geological Survey. These forms are representative of cool shallow fresh to somewhat brackish water in which peat was being formed. The assemblage of diatoms is given below. Relative abundance: $R=$ rare, $\mathrm{F}=$ frequent, $\mathrm{C}=$ common

Amphora sp.-...... R

Caloneis obtusa (Wm. Smith) Cleve. . . . .

Cocconeis placentula Ehrenberg.........

Cymbella cf. C. cuspidata Kützing ...

cymbiformis (Kützing) Brebisson . . . . . . . . . . . F

parva (Wm. Smith) Van Heurck ................ C

ventricosa var. obtusa Grunow . . . .

sp_.

Epithemia argus (Ehrenberg) Kützing ...

turgida (Ehrenberg) Kützing ..................... C

turgida var. granulata (Ehrenberg) Grunow ........... F

zebra (Ehrenberg) Kützing

zebra var. saxonica Kützing

zebra var. porcellus Grunow _._.

zebra var. proboscidea Grunow...................... F

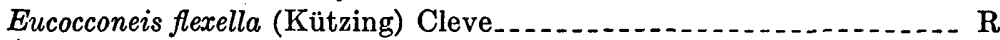

Eunotia praerupta Ehrenberg

Gomphonema intricatum Kützing

lanceolatum Ehrenberg . . .

sp . _...

Mastogloia cf. M. smithii var. lacustris Grunow ............... C

Navicula ef. N. amphibola Cleve..._.

oblonga Kützing ...........

tuscula (Ehrenberg) Grunow . . . . . . . .

sp . . . .

Nitzschia cf. N. amphibia Grunow _.

Pinnularia major (Kützing) Cleve. . .

cf. $P$. viridis var. rupestris Hantzsch . . . . . . . . F

Rhopalodia gibba (Ehrenberg) O. Müller..................... R

Stauroneis cf. S. phoenicenteron Ehrenberg ................. F 
The dominance of lacustrine diatoms indicates accumulation in a lake or pond that had no river in the immediate vicinity, a situation similar to most of todays muskegs.

Nine samples of clay, silt, or peat were collected from selected beds in measured section No. 1 for pollen analysis. The samples were demineralized, bleached, and examined by Estella B. Leopold and Helen Ranson, of the Geological Survey, who reported (written communication, March 1958) :

* * samples 1, 2, 3 and 9 from the silt or clay beds contained very small amounts of pollen, but the others (esp. 5 \& 6) were very rich indeed ***

Frequency of pollen is very low in the early inorganic sediments, and consists almost entirely of non-arboreal types. Tree pollen, which appears first in sample 4, becomes dominant in samples 5 and 6 . The preponderance of spruce pollen in those samples suggests that spruce was growing in numbers at the site of deposition.

All of the plants reported here grow in the Anchorage region today; the fossil pollen assemblage recorded in your samples 5 and 6 appear to reflect a vegetation much like that of modern spruce muskegs in the region.

The pollen counts from one-half square centimeter of slide area of each sample collected from measured section No. 1 (pollen loc. D1243, Anchorage, Alaska) are listed as follows:

Pollen counts from one-half square centimeter slide area Pollen location D1248, Anchorage, Alaska

[Number at top of column is Miller sample number]

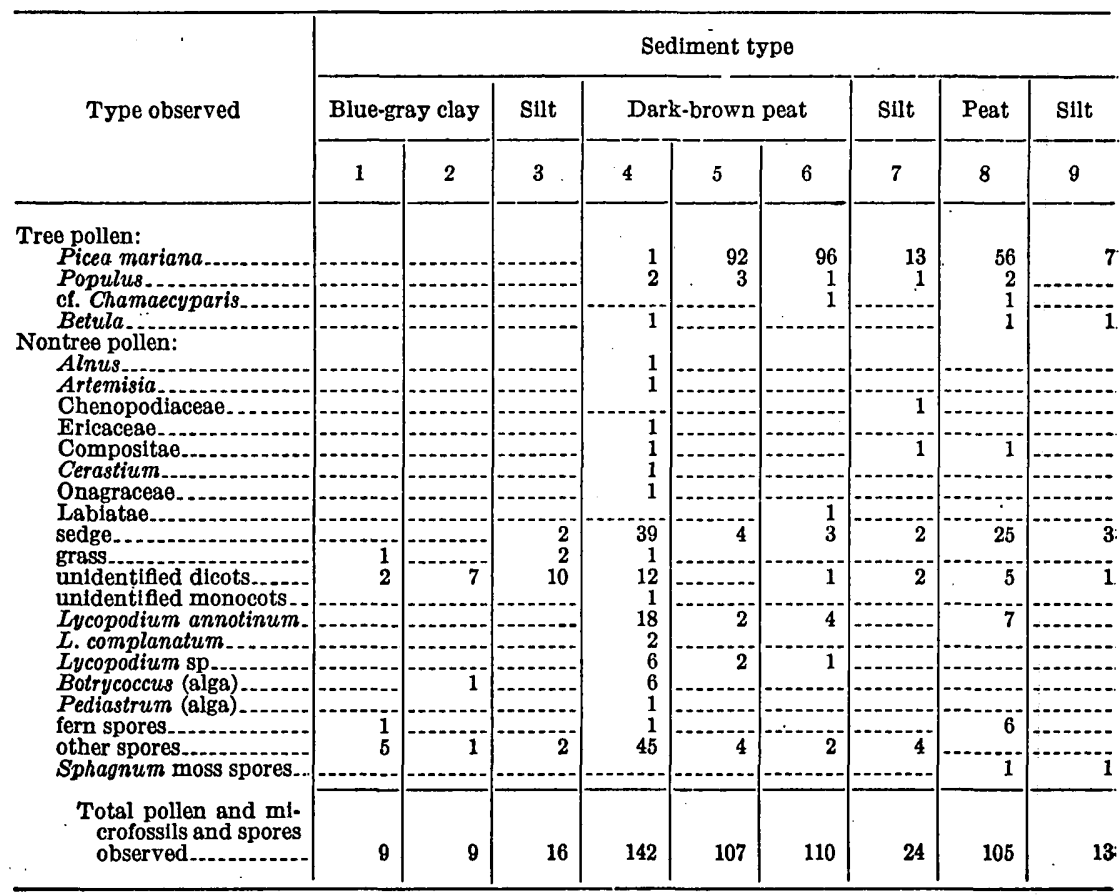


The peat, pollen, spores, and fossils indicate that an interglacial climate produced the deposits that separate the advance outwash of the Knik glacier from the overlying advance outwash of the Naptowne glacier. A measured section of the peat and the advance outwashes in the bluff along the Eagle River, is as follows:

1. Section of the peat and the advance outwashes in $S W 1 / 4 S E 1 / 4$ sec. $9, T .14 N$., R. $\mathscr{Q} W$.

[USGS pollen loc. No. D1243]

Ground moraine of Naptowne age:

Ft In

12. Till, silty sand matrix; pebbles, cobbles common, some boulders present; slump covers most of slope; upper 12 feet well exposed $\pm 45 \quad 0$

Advance outwash of Naptowne age

11. Sand, pebbles common, cobbles locally present; iron-stained lower 3 to 6 inches; slump covers upper part......... $\pm 6 \quad 0$

10. Silt, light-gray

9. Peat, purplish-black, silty _............

8. Silt, greenish-gray; spongy when wet: upper 2 inches yellow: pollen sample 9 from middle

7. Peat, hard, compact; blackish-purple; grades into underlying silty clay; $\mathrm{C}^{14}$ sample A-56-1 (38,000 radiocarbon years, W-535), and pollen sample 8

6. Clay, silty, tan; pollen sample $7 \ldots \ldots \ldots$

5. Peat, compact, lignitelike lower 8 inches; horizontal bedding; ranges from 8 inches to 24 inches in thickness along bluff; pollen sample 4 from lower 6 inches, pollen sample 5 from middle, and pollen sample 6 from upper 6 inches...

4. Silt, yellowish-tan to gray; 2-inch peat layers alternate with fossiliferous ${ }^{1}$ layers; lower contact gradational with unit 3 ; pollen sample 3 from middle of horizon............... _... 8

3. Silt; humic zone(?); lacking in carbon; pollen sample 2... . ... 8

2. Clay, blue-gray, compact; horizontal platy cleavage; clay fills between pebbles in upper layer of underlying gravel; pollen sample 1

-..-

dvance outwash of Knik age

1. Gravel, locally sandy in lower 5 feet, stained brown; cemented layers alternate with uncemented zones, ledge former upper 3 feet; rounded pebbles as large as 3 inches, vein quartz, greenstone, granite gneiss; stained by iron and manganese

Eagle River channel

Total thickness

$\pm 658$

1 Diatoms and gastropods Identified by F. S. McNeil and K. E. Lohman collected from this bed.

The advance outwash was derived from rocks north of the Anchorage area, probably the Matanuska and Knik Valleys, as well as mountain valleys tributary to the Knik Arm lowlands. Sand, pebbles, cobbles, and boulders, for the most part carried in the lower part of the Knik glacier, were deposited by streams as advance out- 
wash in front of the glacier as it moved into the Anchorage area. Advance outwash along Turnagain Arm probably was derived in a similar fashion from debris carried in a Turnagain Arm glacier.

\section{IATERAL MORAINE}

A ridgelike lateral moraine trends south-southwest more than 12 miles along the lower slopes of the Chugach Mountain front in the southeastern part of the area.

The lateral moraine is a system of hummocky composite linear ridges trending south-southwesterly. Two parallel ridges form the major features of the moraine. The higher of the two rises conspicuously about one-half mile east of Lake Hideaway. This ridge marks the eastern edge of the lateral moraine from the area just south of Little Rabbit Creek to Campbell Creek. Ice margin channels form linear valleys in the moraine parallel to the trend of the lateral moraine, though locally some channels turn and transect the ridges. Kettles are numerous; some contain ponds and lakes, some are filled with swampy debris, whereas others are unfilled. The till of the lateral moraine is commonly sandy and stony with cobbles common. Pebbles and sand predominate although angular boulders 10 feet long are scattered throughout the moraine. The upper 4 to 8 feet of till is looser than the underlying till. This looseness may be caused by frost action on the upper part of the till, or it may represent superglacial deposits over a more compact basal till that accumulated under the ice. Silty till-like cobble gravel is common throughout the lateral moraine; in some exposures it shows collapse bedding.

Along the South Fork of Campbell Creek above Campbell Airstrip, near the sharp bend of the gorge, glacial drift that is part of the lateral moraine is well exposed. About 85 feet of pebbly till containing numerous cobbles and boulders overlies bedrock. The till is overlain by about 30 feet of sand interlayered with compact silty gravel in the lower 15 feet. The sand is well stratified and probably was deposited by water flowing in ice-marginal channels. The gravel stands in a vertical bluff, and in part appears only slightly reworked by water. A nearly horizontal boulder layer that is as much as 3 feet thick grades into cobbles and pebble gravel and separates the gravel from the till.

In a cut along Rabbit Creek near the swamp in sec. 35, T. $12 \mathrm{~N}$, R. $3 \mathrm{~W}$., the upper 4 feet of till is brown and is looser than the lower 3 feet, which is light gray and stony. The maximum thickness of the drift in the lateral moraine is estimated to be about 150 feet. About 85 feet of till overlies bedrock near the sharp bend in the gorge along the South Fork of. Campbell Creek. This thickness 
is probably typical for the eastern margin of the moraine. The underlying bedrock surface slopes westward steeper than the surface of the moraine, so the moraine is probably thicker along its western margin than along its eastern margin. Sand and gravel deposits on the floor of ice-marginal channels in the moraine may be as much as 30 feet thick, but are commonly thinner.

The eastern margin of the lateral moraine was deposited at altitudes from about 1,000 to 1,200 feet. The highest altitudes $(1,250$ to 1,400 feet) along the eastern ridge of the lateral moraine are between North Fork Campbell Creek and Rabbit Creek; the lowest altitudes (about 1,000 feet) are near Ship Creek. The lateral moraine slopes northward. The reason for this reversal of topography is that glacial debris from the glaciers in North Fork Campbell Creek, South Fork Campbell Creek, and Rabbit Creek accumulated on the eastern ridge of the lateral moraine. The highest ridge is not entirely lateral moraine but includes end moraines from the tributary mountain glaciers. Because the texture, compaction, and oxidation on the higher and lower ridges are similar, the drifts cannot be separated and the ridges are mapped as a part of the lateral moraine.

Karlstrom (in Péwé, and others, 1953, p. 4) considered the lateral moraine and the materials that cover the lower slopes of the mountains to altitudes of 1,000 to 2,000 feet to be deposits of the Swan Lake glaciation of early Wisconsin age. In his subdivision of the Swan Lake glaciation (fig. 2) into the Eklutna and Knik glaciations of pre-Wisconsin age, Karlstrom (written communication, February 1957) regards the lateral moraine as part of the Eklutna glaciation, and considers it equivalent to the lateral moraines south of Turnagain Arm on the Kenai Peninsula that he designates as Eklutna in age.

In this report the lateral moraine is considered part of the Knik glaciation that deposited the lowland materials. A correlation between the lateral moraine and the older ground moraine is indicated by (1) the relatively unmodified topography of both units, (2) the gradational change in form from the lateral moraine to the ground moraine and the glaciofluvial ice-contact deposits, (3) the similarity of composition, texture, and compactness of the lateral moraine and the older ground moraine, and (4) the similarity in local depths of oxidation of materials in both the lateral moraine and the ground moraine; in most places the depths of oxidation ranges from 4 to 7 feet.

The lateral moraine was derived from talus and avalanche debris that accumulated on and along the margin of the ice as the glacier moved down the Arm from the north. As the glacier thinned, this 
debris accumulated on the slope as conspicuous ridges. The upper margin of the moraine may have been reached when the ice was at its maximum thickness, or it may represent a period of equilibrium in the glacier regimen during downwasting of the ice from a greater thickness. If the latter condition is the case, the debris on the slopes above the lateral moraine and the smoothed spurs along the mountain may be, at least in part, the result of the Knik glaciation.

As the thinning progressed further and the ice margin moved downslope, marginal streams deposited sand, pebbles, and cobbles in their channels along the edge of the glacier.

\section{GROOND MORATNE}

The ground moraine underlies most of the lowland, as proved by wells, although it is overlain in places by deposits of different origins and is largely covered west of R. $3 \mathrm{~W}$. It has a wide surface distribution southwestward from Ship Creek parallel to the mountain front. It covers the lower slopes of the Chugach Mountains between Huffman Road and Potter, and it is coextensive with the lowland south of Anchorage. East and southeast of Anchorage the ground moraine protrudes through the overlying deposits.

A blue-gray silty till beneath the Bootlegger Cove clay and over the advance outwash is exposed discontinuously in the east bluff of Knik Arm. The till is best exposed north of the Eagle River Flats (pl. 3) although locally it is exposed south of the Flats, and east of Knik Arm along the Eagle River. The ground moraine has a gently undulating surface in the area of Huffman and Dearmoun Roads, The swells and troughs are pitted with small kettles. Rounded hills of till stand above the large swamp areas and pitted outwash deposits in the central part of the lowland south of Anchorage. Mounds of ground moraine-mostly drumlins-rise above the swamps and Wisconsin outwash between Ship Creek and Campbell Airstrip. The crestlines of the drumlins are shown on plate 1 .

Adjacent to the lateral moraine, large abandoned melt-water channels, incised as much as 60 feet into the ground moraine, break the continuity of the moraine surface. North of O'Malley Road, smaller unmapped channels parallel the lateral moraine for most of their distance, but trend toward the lowland near the lower part of their courses.

The ground moraine is predominantly compact till that contains pebbles, cobbles, and boulders. Ridges and knobs of stratified or unsorted loose sand and gravel rest on till of the ground moraine locally and in places cover it. A small esker (not mapped) is preserved in the NE $1 / 4$ sec. 18, T. 13 N., R. 2 W. Almost every exposure contains striated and soled cobbles and boulders (pl. 4); 
practically every boulder on the surface of the ground moraine is striated. The till varies appreciably in texture. In some exposures it has a clayey matrix and a heterogeneous mixture of fragment sizes. In other exposures it is more sorted, such as along the access road to the Campbell Airstrip in the NW1/4 NW1/4 sec. 10, T. $12 \mathrm{~N}$., R. $3 \mathrm{~W}$. where the till is predominantly silt, sand, small pebbles, and scattered boulders. In a cut 12 feet deep along Rabbit Creek Road, a silty pebble till that has a platy cleavage is interpreted as basal till.

In most exposures, the till of the ground moraine is moderately hard and compact, though the upper 2 to 6 feet may be loose and unsorted. In general, the till of the ground moraine is more compact than the till of the lateral moraine. Erratics 6 feet long are common. Here and there are lenses of stream-laid sand and pebbles. The till of the Knik glacier north of the Eagle River Flats beneath the Bootlegger Cove clay is dark blue gray, silty to clayey, and contains pebbles, cobbles, and boulders. A buried weathered zone 20 inches to 2 feet deep at the top of the till is tan in some exposures and reddish brown in others. Along the Eagle River in the NW1/4NW1/4 sec. 17, T. 14 N., R. 2 W., Knik till 12 feet thick consists of cobbles and pebbles in a silty clay matrix. The upper 4 feet is oxidized brown, whereas the lower 8 feet is blue gray.

Tills of two possible ages are exposed in a drumlin on the south side of the Glenn Highway in sec. 12, T. 13 N., R. 3 W. Beneath 2 feet of silty humus is a 3 -foot thick horizontally plated gray silty till. Pebbles have a sandy coating and are stained purplish black. Below is a 4-foot-thick section of a compact silty till that also contains black-stained pebbles, and underlying this compact till is a more sandy gray pebble till. A time break in the till sequence conceivably could be placed at the top of the 4-foot compact silty till.

One-half mile east of the Seward-Anchorage Highway, an 8-foot cut along O'Malley Road contains oxidized till. The upper 5 feet is reddish brown and has a nutlike structure. This is one of the thickest and most intensely oxidized zones on the Knik ground moraine recognized in the area. The thickest exposure of till in the ground moraine seen by the authors is in an old pit 100 yards north of Potter where it is 118 feet thick. About 70 feet of till is exposed in a gravel pit along the Ski Bowl Road in the NE1/4 $\mathrm{SE}_{1} 1 / 4$ sec. 8 , T. 13 N., R. 2 W. In cuts in the sea cliff along the Alaska Railroad in secs. 29 and 32, T. 12 N., R. 3 W., gray till ranges from 22 to 38 feet in thickness. A dug well in the SE1/4 sec. $29, \mathrm{~T} .12 \mathrm{~N}$., R. $3 \mathrm{~W}$, near the border of the ground moraine and the pitted outwash, penetrated 66 feet of silty till with boulders. Silty clayey till 45 feet thick is exposed in a hill of ground moraine north of Ship Creek in the SW1/4.SE1/4 sec. 31, T. 14 N., R. 2 W. Published drill- 
well records (Cederstrom and Trainer, 1953) are interpreted by the authors as recording a maximum thickness of ground-moraine deposits of more than 130 feet.

Blue-gray till overlies the Knik advance outwash and underlies the Bootlegger Cove clay along the east shore of Knik Arm. That the ground moraine south of Anchorage also underlies the Bootlegger Cove clay has been determined from well records (Cederstrom and Trainer, 1953, nos. 33, 46, 48, 69, 90). Because of the similar stratigraphic position, the till along Knik Arm and the ground moraine are considered as the same unit.

The position of the drumlins south of the Elmendorf Moraine, however, is not so clear cut. Examination of the material that consitutes the drumlins along the Glenn Highway in sec. 12, T. 13 N., R. 3 W., suggests that they contain more than one till. The upper 3 feet of till is horizontally plated and has sandy coated purplish-black stained pebbles. The underlying 4 feet of compact silty till also contains purplish-black-stained pebbles. The horizontal cleavage in the uppermost till may indicate basal till that was deposed over a preexisting till hill. The overriding by the later glacier may have formed the drumlins. A gray clay that can be interpreted as Bootlegger Cove clay underlies a drumlin in the $\mathrm{NE} 1 / 4$ NW1/4 sec. 12, T. 13 N., R. 3 W. (Corps of Engineers unpublished well records, No. 55, well 6 , No. 62, well 3).

Samples of till from two exposures of ground moraine were collected for analysis of clay minerals in an attempt to determine any alteration of minerals owing to weathering processes. Interpretation by H. C. Starkey and Gillison Chloe (IWM-871) of the U.S. Geological Survey of the results showed that sample $A-21$ (pl. 7), till collected from the 8-foot exposure of ground moraine one-half mile east of the Seward to Anchorage Highway, contains mixed layered chlorite and montmorillonite (4 parts in 10) that suggest a longer interval of weathering than does the analysis of till along the bluff of Turnagain Arm (sample $A-22$ ) where only the upper 18 inches of a 22- to 38-foot thickness of till is oxidized. Though only suggestive, the possibility exists that two tills are represented, and the till along Turnagain Arm may in reality be a remnant of an end moraine of Wisconsin age from a Turnagain Arm glacier. A ridge that trends northwest from Potter to the vicinity of Dearmoun Road may be the arc of the end moraine lobe. The till hills in sec. 23 , T. 12 N., R. 4 W., which rise above the swamp area south of Sand Lake Road, may be remnants or outliers from this supposed moraine.

Such relationships can not yet be explained satisfactorily, and because of this incomplete understanding, the drumlins south of the 
Elmendorf Moraine, and the till along Turnagain Arm are mapped as part of the ground moraine of Knik age.

The ground moraine was derived from rock particles of all sizes that accumulated north of the Anchorage area and that were carried (1) in the lower part of the glacier, (2) within the body of the glacier, and (3) on the surface of the glacier. The ground moraine was deposited as basal till and superglacial till as the glacier thinned and the area was deglaciated. Widespread ice-contact features on the ground moraine and associated Knik age deposits indicate stagnation as the cause of deglaciation.

\section{DELTA DEPOSITS}

The high ridge between Point Campbell and Point Woronzof, mapped by Karlstrom (1950) as a moraine on the basis of topographic form, is called a delta in this report and is considered to be a glaciofluvial deposit because (1) the body of the ridge is not till but is composed almost entirely of fluvial sand and gravel, (2) intimately associated silt, sand, gravel, and blocks of till indicate close proximity to a glacier, (3) the bedding is deltaic, and (4) the high plane surface of the ridge is covered with kames and kettles.

The high ridge of the delta extends from Point Woronzof on Knik Arm to Point Campbell on Turnagain Arm. It is about 4 miles long and ranges from $1 / 2$ to 3 miles in width. Part of the eastern boundary forms the western shore of Jewel Lake and the northern, western, and southwestern shores of Sand Lake; near Knik Arm, the boundary coincides with the western border of a large swamp. The delta grades indefinitely into prodelta deposits, pitted outwash, and glacial silt near the International Airport. The eastern boundary is marked by topographic differences between the higher ridge area and the more level surface of the prodelta deposits and the pitted outwash area.

The delta deposits are well exposed along Turnagain Arm near Point Campbell and along Knik Arm from Point Woronzof east for about 1 mile to a point where they disappear beneath the Bootlegger Cove clay. The delta consists topographically of three parts: the high land around Point Woronzof, the high land around Point Campbell, and an area sloping east from the high land around Point Campbell.

The high land at Point Woronzof is a ridge that extends south about $1 \frac{1}{2}$ miles. The west slope of the ridge is erosional and moderately steep, the east slope is depositional and more gentle. The surface crest of the ridge, covered with small kames and pitted with kettles, slopes southward toward a saddle that separates the Point Campbell ridge from the Point Woronzof ridge. The saddle is marked by more numerous kames, kettles, and overflow channels. 
The topographic boundary is distinct between the Point Woronzof ridge and the overflow channel, and between the overflow channel and the high land at Point Campbell. Point Campbell is part of a relatively flat tableland that slopes to the north and east and grades into the lowland. The tableland is covered with kames and pitted with kettles. One high mound covered with kames stands above the general level in the SW1/4 sec. 5, T. 12 N., R. 4 W.

The eastern slope of the high land at Point Campbell is pitted by large circular or elongate kettles, a small percentage of which contain ponds or small lakes, such as Campbell Lake. Most of the kettles are not filled because the sand permits unrestricted downward movement of the water. One spectacular circular kettle with raised edges is at the end of a road in the NW1/4 SW1/4 sec. 9, T. 12 N., R. 4 W. The western slope of the tableland is steep and bounds the east side of a flat surface, about 4 miles long and ranging in width from about 450 feet to about 1,800 feet, that parallels the seaward side of the delta. The surface slopes from more than 50 feet above sea level near Point Woronzof to about 30 feet above sea level near Point Campbell. A low scarp on the east. side of the surface separates it from the pre-Wisconsin abandoned-channel deposits. A similar flat surface is evident on the eastern end of Fire Island.

The materials in the delta are almost continuously exposed in the sea cliffs from the east line of sec. 8, T. 12 N., R. 4 W. to Point Campbell along Turnagain Arm, and from near the east line of sec. 21, T. 13 N., R. 4 W. to Point Woronzof along Knik Arm. To describe the deposits better, the Point Campbell and Point Woronzof areas are discussed separately.

In general, stratified deposits of cobbles, pebbles, sand, silt, clay, and, in places, blocks of till compose the delta along Turnagain Arm. Sand and silt alternate in layers that dip slightly out of the bluff. The sand is gray, fine to medium, well sorted, and contains scattered round to subrounded pebbles and cobbles. Slightly silty, the sand locally stands in almost vertical breaks. Small channels or lenses of coarser sand that contain fragments of coal one-sixteenth of an inch to 8 inches in diameter are included in some of the sand layers. In some exposures the lamina in the sand dip about $10^{\circ} \mathrm{S}$. to SW. Tan to brown silt layers, intimately interlayered with gray clay, pinch and swell. The sand layers commonly range in thickness from 1 inch to $2 \frac{1}{2}$ feet and are generally thicker than the silt layers. In places, the sand layers are ripple marked at the top, and differential erosion between the sand and the overlying silt results in overhanging molds of the ripple marks on the undersides of projecting silt ledges. Though thin in most places, the silt lay$507199-60-3$ 
ers locally may be as much as 6 feet thick. Some silt layers that contain lenses of medium sand from one-half to 1 inch thick show contemporaneous deformation.

Some exposures along Turnagain Arm do not fit this description. An example of the variable composition of the delta deposits is shown in a scar that extends from the top of the sea cliffs down to the beach in the NE1/4 SE1/4 sec. 8, T. 12 N., R. 4 W. The lower 40 feet is covered by slopewash and slump, but above that, 38 feet of gray silty till is exposed that contains cobbles and boulders and is probably an older predelta deposit. A gray crossbedded pebble and cobble gravel which ranges from 44 to 68 feet thick overlies the till and is overlain in turn by gray medium sand from 58 to 73 feet thick which shows tangential crossbedding that dips in general about $15^{\circ} \mathrm{SE}$. Coal fragments are concentrated in layers within silt, sand, and gravel layers. Abrupt truncation of the layers are common. About 3 feet of dune sand tops the bluff.

About 1,000 feet from Point Campbell southeast along Turnagain Arm, sand, pebble and cobble gravel, and till are intimately associated in an exposure that extends from the beach to the top of the bluff. The till is in two large blocks, one enclosed in the gravel, the other in the upper part of the gravel and overlain by dune sand at the top of the bluff. The gravel contains silt lenses and is slightly contorted near the till. A section measured from high tide follows:

2. Section along Turnagain Arm in NE1/4 NW1/4 sec. $7, T .12 N ., R .4 W$.

5. Sand, fine to very fine, tan; bedding dips into hill from $30^{\circ}$ to $40^{\circ}$;

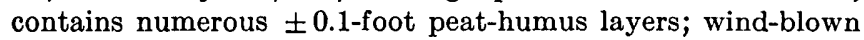
sand; active dune .

4. Till, silty, contains pebbles and cobbles; tan; compact; unsorted, with pebbles, cobbles, and boulders common: lenses of silt, sand, and pebble gravel contorted; part of till covered by vegetation, lower part covered by slump, western part of till bounded by sand of unit 5

3. Gravel, pebble to cobble, about 10 percent is larger than 3 inches in diameter; gray; lower part slumped; pebbles and cobbles subangular to round; obscured bedding appears to dip southwest; gravel near till only slightly contorted; upper part has silt and sand lenses.

2. Sand, very fine, some silt; gray; tan where more silty; silt lenses common; coal fragments scattered throughout; more or less evenly bedded with some beds truncated, may be deltaic with foreset-bottomset contact; average dip of sand lamina about $10^{\circ}$; contains a few lenses 1 foot thick of pebble gravel and reworked coal; upper part more silty and contact with gravel appears gradational . . . . . 58

1. Beach, sand, pebbles and cobbles

Total thickness 
Almost continuous exposures from Point Woronzof southeast along Knik Arm provide a cross section three-quarters of a mile long through the delta deposits. In general, the deposits range from coarse cobble gravel at Point Woronzof to sand and silty sand where the delta underlies the Bootlegger Cove clay. The lower slope of the sea cliff (1956) is about $50^{\circ}$ to $55^{\circ}$. At several places along the bluff, beds of silt, sand, and gravel in the delta, intimately interlayered and apparently in place, have apparent dips that range between $40^{\circ}$ and $50^{\circ} \mathrm{SE}$. In the $\mathrm{NW} 1 / 4 \mathrm{NE} 1 / 4$ sec. $29, \mathrm{~T} .13$ N., R. 4 W., 22 feet of moderately well-sorted sand and gravel, which dips east about $30^{\circ}$ and displays small displacements from slump or consolidation, overlies a boulder layer 2.5 feet thick that interfingers with a fine sand. Overlying the sand and gravel is about 10 feet of crossbedded sand that dips about $30^{\circ}$ E., and contains lenses of black-stained gravel. The upper 3 feet of the exposure is a well-sorted, horizontally bedded fine to medium gravel. The lower 16 feet of the bluff is covered by slump. About 300 feet southwest of Point Woronzof, pebble to cobble gravel has silt layers 10 inches to 3 feet thick in the lower 30 feet. The gravel thins to the north or northeast, which suggests a western or southwestern source for material. At 150 feet southwest from Point Woronzof, the lower part of the bluff has a northeastward steeply dipping cobble gravel that is overlain by 6 - to 10 -inch silt layers in the upperpart. A less steeply dipping (about $15^{\circ}$ ) silty sand truncates the gravel. At Point Woronzof, a medium sand constitutes the lower 20 feet of the bluff. Gravel overlies the sand.

Alternating silt and sand layers in the lower 20 feet have the appearance of foreset beds to the observer looking $90^{\circ} \mathrm{SW}$. from the direction of deposition (SE.). About 1,200 feet southeast of Point Woronzof, the gravel has more pebbles but fewer cobbles, has a lower dip, and is slightly crossbedded. Silty sand overlies the gravel along the entire horizontal distance. The amount of pebble gravel decreases still further southeast along the Arm until about 2,500 feet from Point Woronzof, the bluff is composed of sand containing $1 / 2^{-}$to $11 / 2^{-i n c h-t h i c k ~ l e n s e s ~ o f ~ p e b b l e s ~ h i g h ~ i n ~ t h e ~ s e c t i o n ~}$ (pl. 4). Apparent warping of layers may be a curvature of the surface of deltaic beds. Some of the sand beds have steep dips, are crossbedded, locally contain alluvial coal, and are truncated by evenly bedded sand. Interfingered with the even-bedded sand are lenses of fluvial coal about 1 foot thick and 10 feet long. About six-tenths of a mile from Point Woronzof, the bluff is composed almost entirely of gray sand that has some tan silt layers. Coal fragments, in layers in the sand, are iron stained. Further east along the bluff, beyond the high ridge toward the lowland area, the Bootlegger Cove clay interfingers with sand and silt of the delta. 
What appears to be a blue-gray clayey till along the bluff, is on close examination, only slump material from the Bootlegger Cove clay mixed with sand, silt, and a few pebbles. About 30 feet of brown sand and sandy silt at the base of the bluff underlies 15 to 20 feet of the Bootlegger Cove clay that in turn is overlain by tan sandy silt that extends to the surface. The lower silt and sand is inclined and passes beneath the Bootlegger Cove clay so that about 1 mile from Point Woronzof, only the Bootlegger Cove clay is exposed in the bluff. The easternmost exposure of the sand and tan sandy silt below the Bootlegger Cove clay is near the outlet of the drainage ditch in the NW1/4 SW1/4 sec. 22 , T. 13 N., R. 4 W.

Exposures between Point Campbell and Point Woronzof are not common. One of the better exposures is in a small gravel pit in the SW $1 / 4$ NW1/4 sec. 33 , T. 13 N., R. 4 W., near the Alaska Communications System Station where silt layers in pebble and cobble gravel lenses are contorted. The log of a water well 240 feet deep, the collar of which is 140 feet above sea level, near this station (Cederstrom and Trainer, 1953, No. 97) lists a clayey sand in the upper 30 feet of the delta at that point. Deposits logged above the 140-foot depth are for the most part sand containing some coal. Deposits logged below 140 feet are predominantly sand and gravel to the 187-foot depth and below that depth the material is gravel. Till was indicated from 40 to 50 feet, and probable till from 30 to 40 feet. Below 140 feet, 1 foot of till is recorded between 141 and 142 feet, 9 feet of till between 200 and 209 feet, and four other possible tills in the lower 31 feet, each of which range from 2 to 7 feet in thickness. Reinterpretation of the well log by Cederstrom and Trainer (written communication, January 1957) places till between 30 and 61 feet, and between 160 and 235 feet. The high ridge may be composed of interlayered silt, sand, and gravel containing till. This compares favorably with the exposures in the sea cliffs near Point Campbell and Point Woronzof.

Varied materials are exposed by pits and road cuts in the eastern part of the delta deposits. A pit in the SE1/4 SW1/4 sec. $4, \mathrm{~T} .12 \mathrm{~N}$., R. $4 \mathrm{~W}$., contains steeply dipping gravel that appears deltaic in origin and is similar in bedding, sorting, and degree of disturbance, to the prodelta gravel in the pit west of the road in the $\mathrm{SE} 1 / 4 \mathrm{SE} 1 / 4$ sec. 9, T. 12 N., R. 4 W. The gravel also appears to extend westward under a hill west of another gravel pit located in the SW. corner of sec. 4 . The hill, a ridge on the delta, is cut by Kincaid Road, where gray crossbedded medium sand contains silt layers and angular cobbles and boulders. Part of the sand is distorted, crenulated, and faulted. The crossbedded sand is truncated by other sand layers. 


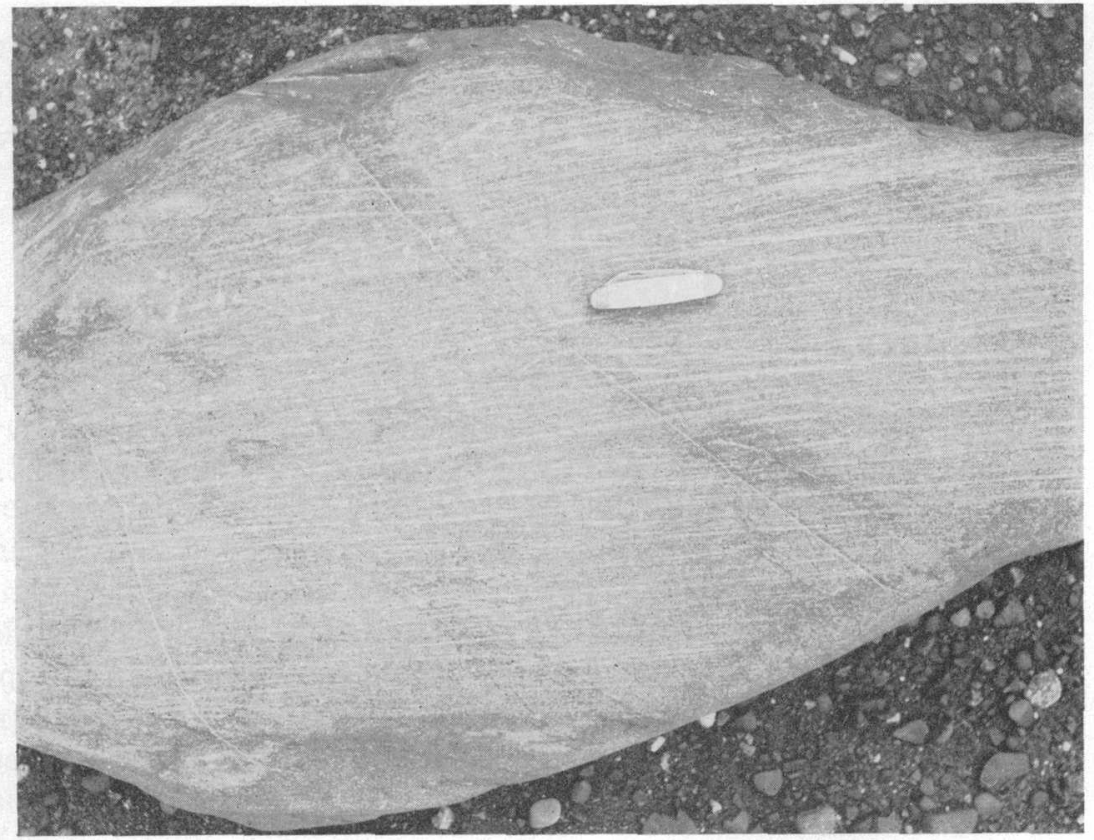

$A$. Soled and striated greenstone boulder from till of Naptowne age north of Cairn Point along east side of Knik Arm.

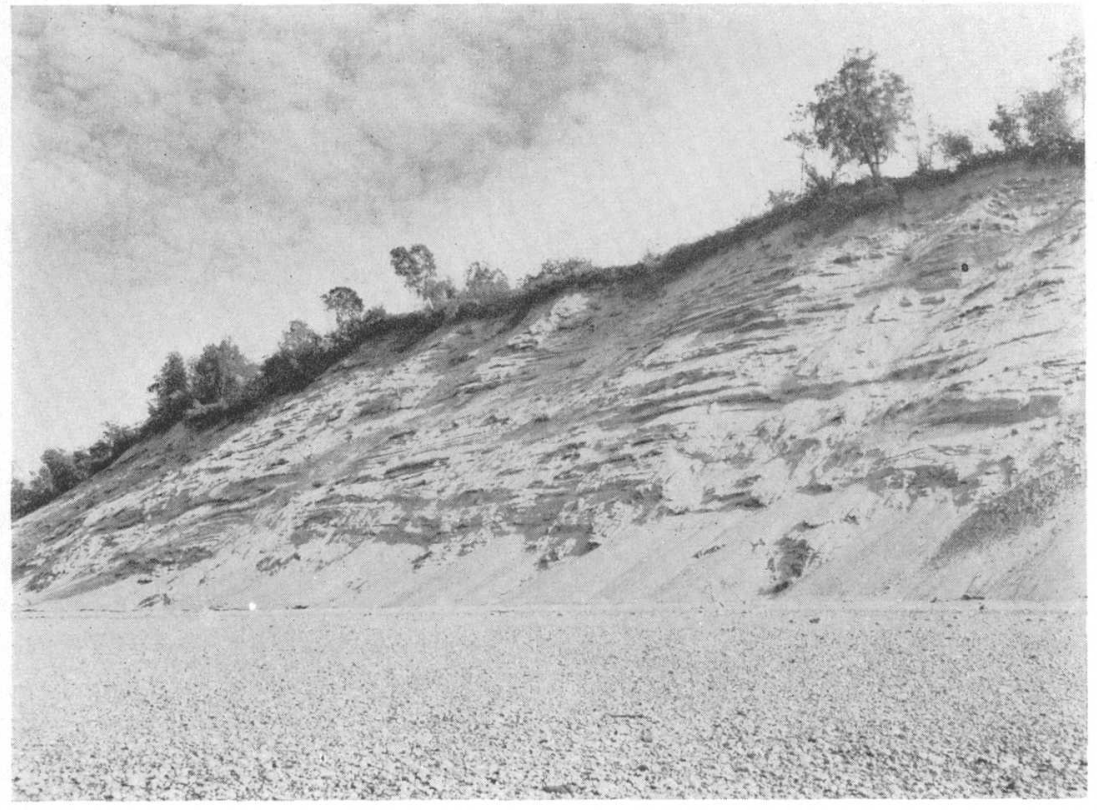

$B$. Delta deposits, looking south into bluff along south shore of Knik Arm near Point Woronzof. Photograph by W. R. Hansen. 


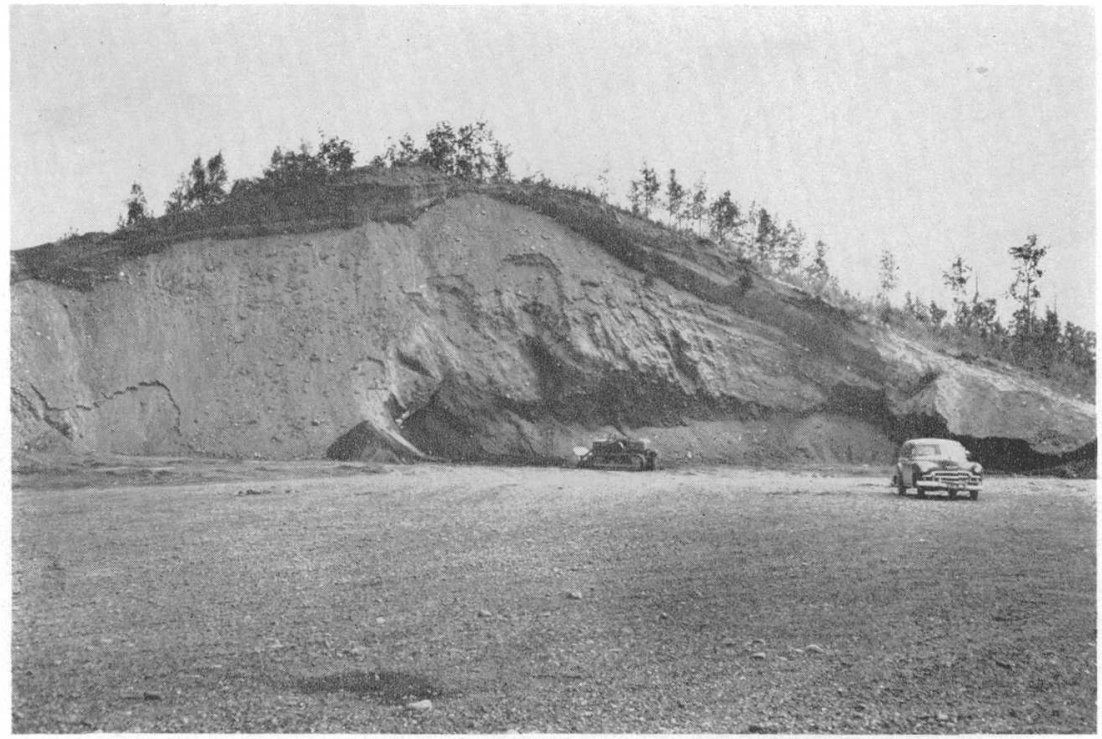

A. Kame showing inclined bedding; west end of O'Malley Road, in the NW1/4NW1/4 sec. 20, T. 12 N., R. 3 W. Photograph by W. R. Hansen.

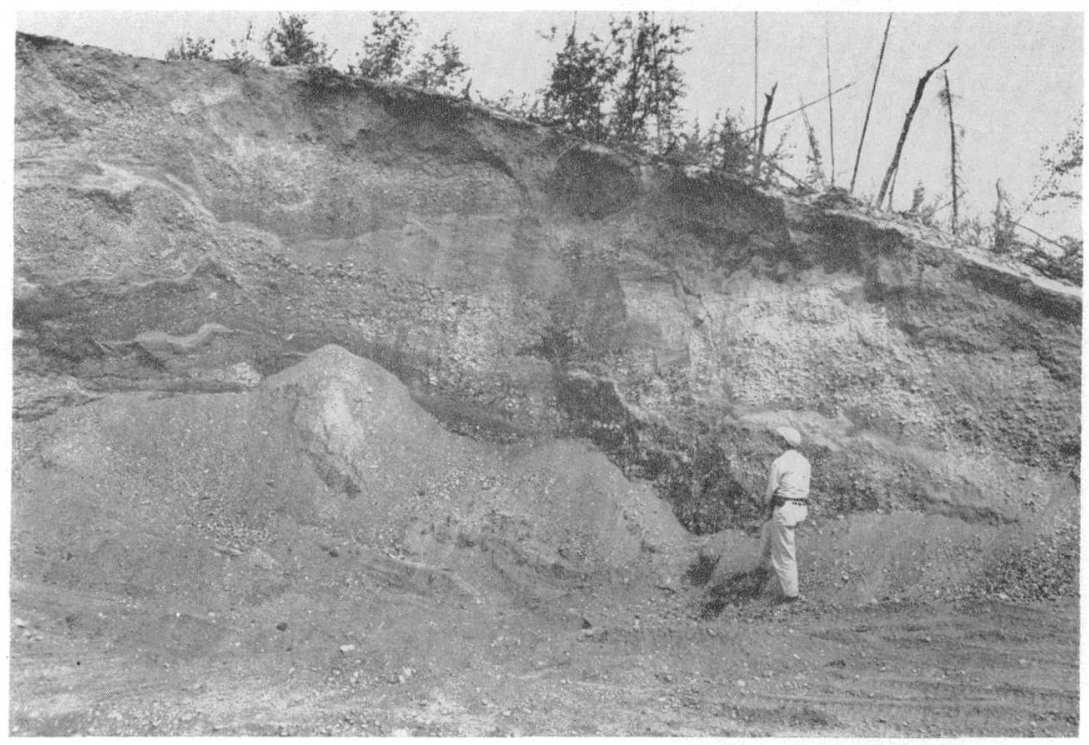

$B$. Kame deposit showing pebbly till at right and normal faulting of sand and pebble gravel beds at left of figure. Exposed in gravel pit in SE $1 / 4 \mathrm{NE}^{1 / 4} \mathrm{sec} .18, \mathrm{~T}, 12 \mathrm{~N} ., \mathrm{R}, 3 \mathrm{~W}$. Photograph by W. R. Hansen. 
A 230-foot bluff near Point Campbell contains the maximum exposed thickness of the delta deposits. There is no indication in the record of well 97 (Cederstrom and Trainer, 1953), which extends 100 feet below sea level, of any change in materials that would establish the lower limit of the deltaic deposits. Thus the maximum thickness is more than 330 feet.

The Point Woronzof and Point Campbell highland area rises 125 to 150 feet above the lower lying glacial deposits on the lowland around Lake Spenard and Sand and Jewel Lakes. The highland is different both topographically and stratigraphically from the lowland around it. The highland appears from its geographic and topographic position to be a segment of a morainal ridge deposited by a glacier from Turnagain Arm and to be continuous with Fire Island, however, for geologic reasons this origin does not seem to fit.

Stratified deposits dip eastward from Point Woronzof and interfinger with the Bootlegger Cove clay. Along Turnagain Arm, the layers dip southeastward in the sea cliff, so that deposition probably was from the west or northwest. Coal fragments are either scattered throughout the stratified deposits, or, in places, are concentrated in lenses and layers along both Turnagain and Knik Arms. The only known coal exposures are on the west side of Cook Inlet southwest of the area, up the Susitna River valley to the northwest, or up Knik Arm and the Matanuska Valley to the north. No coal deposits are known along Turnagain Arm.

The lack of coal, either in the advance outwash near Potter, or in the stratified deposits up Turnagain Arm, suggests that materials derived from Turnagain Arm are coal free. This interpretation coupled with the southeastward dips of the layers in the delta deposits, and with the similarity between the stratified deposits on Fire Island and on the Point Woronzof and Point Campbell highland, indicates that the delta deposits were derived from either the west or northwest side of Cook Inlet or the Susitna Valley, and not from Knik Arm.

Fire Island, in the middle of Turnagain Arm off Point Campbell, is important in the interpretation of the origin of the older delta deposits. The senior author and W. R. Hansen visited Fire Island in June 1956 to examine the deposits that form the island. Compact silty till, locally hard and stony, forms the surface of the island, except for sand dunes along the east and southeast bluff, and a gravel-covered flat surface at the northeast end of the island. Underlying the till on the west side of Fire Island, near Race Point, is a medium sand with one-fourth to one-half inch fragments of coal scattered throughout. The appearance of the stratified deposits on Fire Island is the same as the materials exposed near Point Camp- 
bell. On the east side of the Island intermixed till, silt, sand, and gravel compose the moraine. A 5-foot layer of peat overlies till on the south bluff about 1 mile east from the Fire Island light. A radiocarbon determination of a sample collected at the base of the peat section gave an age of 9,300 \pm 250 radiocarbon years (Rubin, Meyer, U.S. Geological Survey, written communication April 2, 1957, W-536). Thus, the minimum age of the moraine is about 9,000 radiocarbon years, but the maximum or absolute ages are not known. The following hypothesis is presented although no one theory of deposition known to the authors is completely satisfactory in all details.

A lobe of either the Susitna Valley glacier or a glacier from the Alaska Range on the west side of Cook Inlet extended into the area south of Anchorage. Melt water from at least the MatanuskaKnik lobe and possibly the Susitna lobe apparently was ponded behind this ice barrier across what is now Cook Inlet. Melt water from the "barrier" glacier deposited its load in part as a delta into the ponded waters, and in part as an end moraine. Most of the crossbedding in the delta deposits exposed along Knik Arm is confined within thin units that are dipping about $10^{\circ}$ to $30^{\circ} \mathrm{E}$. The crossbedding within a unit is steeper than the overall dip of the unit, and commonly ranges between $20^{\circ}$ and $40^{\circ}$ to the east. If the deposits were built forward as a delta into standing water the crossbedding would likely extend the entire height of the delta, rather than be confined within thin beds. One condition of deposition that could account for the lack of long deltaic crossbeds is that the level of the lake increased continuously as the sediments were deposited, but stayed barely above the level of the topmost layer of sediment. In this manner, thin crossbedded layers could be piled up on top of each other.

The delta extended from a point west of Fire Island to the Point Campbell and Point Woronzof area. Further advance by the lobe from the eastward-moving glacier over its delta, resulted in deposition of the till, in part deposited in the ponded water, that forms the moraine at Fire Island. The ice front stood between Fire Island and Point Campbell. Evidence that the glacier was near Point Campbell and that blocks of ice probably were rafted into the delta deposits is: (1) the accumulation of till over the stratified deposits on Fire Island; (2) the presence of tilted blocks of till above the stratified deposits near Point Campbell; and (3) the knobs and kettles on the surface of the delta. Thus the delta is a proglacial feature, and may be equivalent to an end moraine.

Fire Island and the Point Campbell-Point Woronzof highland were connected after deglaciation. Subsequent erosion by the wa- 
ters of a combined Matanuska and Knik River, coupled with the waters of Turnagain Arm and Cook Inlet, separated the areas. At lowest tide, boulders as much as 30 feet in the longest dimension, cover the tidal flats between Point Campbell and Fire Island. They are probably remnants of the moraine that originally extended almost to Point Campbell.

The flat surface along the western side of the delta originated either before or during erosion of the delta deposits. Assuming that the formation of the surface was contemporaneous with the erosion of the delta, wave action at sea level probably cut the flat surface. The thin cover of reworked sand and gravel was deposited on the underlying deposits of the delta. Rebound of the surface in Recent time, or perhaps lowering of the sea level, raised the beveled surface relative to the sea and resulted in a wave-cut bench elevated above modern sea level.

An alternative origin is favored by the authors. Prior to erosion of either the moraine supporting the delta, or the delta itself, the lake in which the delta and Bootlegger Cove clay accumulated may have overflowed along several channels. The channel in the saddle between Point Campbell and Point Woronzof is one such channel. Overflow waters subsequently scoured a channel, somewhere west of Point Woronzof, through which the lake drained southward, as suggested by the gradient of the flat surface. The overflow channel in the saddle between Point Campbell and Point Woronzof was eroded, and a scarp marks the boundary between the two channels. Erosion by the waters of Cook Inlet removed much of the delta and the overflow channel deposits. The flat surface along the delta and along the east end of Fire Island could be considered remnants of either one large or several smaller overflow channels. The gradient of the flat surface suggests that the lake was not yet drained before the delta was eroded by the waters of Cook Inlet.

The silts in the bluffs near Point Campbell and Point Woronzof are predominantly tan to brown. Silty sand and gravel also are tan to brown. Silt and sand layers adjacent to layers of coal fragments are an intense brown. The color is considered to be secondary rather than primary and caused by oxidation. The oxidation extends from the top of the bluff to the beach level, a thickness of as much as 175 feet. Karlstrom (oral communication, July 1956) considered the oxidation to be related to a weathering profile, and in March 1957 (written communication) he reiterated his belief that the delta is part of the Eklutna glaciation rather than part of the Knik glaciation. Three methods of oxidation, however, seem plausible to the authors; oxidation as part of a weathering profile, oxidation that extends inward from the surface for several feet, and that is 
continuing at the present, and oxidation by ground water moving along permeable layers. The authors favor oxidation by circulating ground water for the following reasons:

(1) Layers of gray clay and silty clay 1 to 10 inches thick are unoxidized even though layers of oxidized $\tan$ silt or silty sand overlie and underlie the clay. If weathering produced the oxidation, the clays would either be oxidized along with the other materials, or else the clays would act as a barrier and prevent oxidation of the underlying materials.

(2) Layers of sand and fine gravel that contain coal fragments are oxidized. The coal fragments have a brown rim, and the color continues into the surrounding sand or gravel. The coloration is caused by oxidation of the pyrite in the coal fragments.

(3) Oxidation of the bluff is not uniform from the top to bottom, instead, layers of tan to brown silt, sand, and gravel, alternate with layers of gray clay, silty sand, and silty gravel. Oxidation proceeding inward at the present time would also include these layers. Thus, the apparent thickness of oxidation is relative neither to the length of time available for weathering, nor to the age of the deposits.

Deposits of the delta underlie, and interfinger with, the Bootlegger Cove clay along Knik Arm. The delta, thus, is either contemporaneous with, or older than, the Bootlegger Cove clay. The tan silts that underlie the Bootlegger Cove clay are believed to have been oxidized by circulating ground water and not by surface weathering. The delta, the prodelta deposits, and the pitted outwash deposits that show ice-contact features are intimately related. The delta thus is considered to be part of the pre-Wisconsin Knik glaciation.

\section{PRODELTA DEPOSIT}

Stratified sand and pebble and cobble gravel with local steep dips from the west and northwest flank the eastern margin of the delta. Northeasterly or easterly dips are not compatible with the dominant direction of dip of materials in the pitted outwash, which appears to originate from the north. Though part of the delta, it is here called a prodelta deposit because the flatter surface expression is distinct from the steeper delta deposits.

The surface of the southern part of the prodelta deposit near Jewel and Sundi Lakes is smooth and nearly level, though sloping gently toward Jewel Lake. North of Jewel and Sundi Lakes, rounded hills slope gently toward Jewel Lake, and rise above the generally level surface to the south. Steep slopes of ice-contact deposits bound the east margin of the prodelta deposit around the shores of Sand, Sundi, and Jewel Lakes. 
Sand, pebble and cobble gravel, olive gray (5 $Y$ 3/1) when dry and darker olive gray (5 $Y$ 4/2) when moist, constitute the materials in the prodelta deposits. Sand and gravel are commonly at the surface. The prodelta deposits contain sand and gravel layers that range from horizontally bedded to steeply dipping or crossbedded; from well sorted to poorly sorted; from undisturbed to contorted. A 61-foot section measured along the east side of the road in the NE1/4 sec. 9 , T. 12 N., R. 4 W., consists of olive-gray crossbedded medium sand in which a deep red-brown oxidation is noticeable along some of the layers. Pebble gravel is interlensed with the sand, and coal fragments are scattered throughout the section. The upper 10 feet contains lenses of coarser angular material. The apparent dip of the laminations in the sand ranges from horizontal to about $70^{\circ}$ from the west.

In a gravel pit in the SW. cor. sec. 10, T. 12 N., R. 4 W. the dip of layered sand and gravel ranges from horizontal near the surface to $30^{\circ}$ from the northwest at shallow depth. Coal layers are common.

The prodelta deposit accumulated in a glacial lake as a frontal part of the delta. The lake waters surrounded stranded blocks of glacial ice, some of which exceeded 1 mile in longest dimension. As the delta encroached into the lake, sand and gravel were deposited over some of the smaller blocks and around some of the larger blocks. The prodelta deposit was laid down by streams flowing eastward and southeastward, as shown by the gradient of its surface and the dips of the foreset beds.

\section{BOOTLEGGER COVE CLAY}

The Bootlegger Cove clay is here named for the light-gray silty clay, locally called the "blue clay," that is conspicuously exposed in the bluffs along Knik Arm. Typical sections of the Bootlegger Cove clay are in the SW $1 / 4 \mathrm{NE} 1 / 4$ sec. 23, T. 13 N., R. 4 W. near Bootlegger Cove for which the unit is named. The Bootlegger Cove clay is exposed almost continuously from a point about three-fourths of a mile southeast of Point Woronzof northward to a point about half a mile southwest of the Eagle River Flats. North of the Flats it is exposed discontinuously in the bluffs. In some places, stream erosion has removed the clay to below sea level. The Bootlegger Cove clay underlies sand and gravel in the banks along the lower courses of Ship, Chester, and Fish Creeks. Well logs record blue clay, interpreted by the authors as Bootlegger Cove clay, beneath outwash sand and gravel at Anchorage, beyond the SewardAnchorage Highway in sec. 20, T. 13 N., R. 3 W., under Mountain View, and under most of Elmendorf Air Force Base (pl. 5). The 
extent of the Bootlegger Cove clay in the northern part of the area is not known, but the clay is assumed to extend under the Wisconsin advance outwash and ground moraine for at least one-fourth mile east of Knik Arm, and probably farther.

South of Anchorage, a clay correlated by the authors as the Bootlegger Cove clay underlies the Hood and Spenard Lakes area (Cederstrom and Trainer, 1953, well $\operatorname{logs} 73,80,81$, and 88) and the International Airport, and appears to extend beneath the Knik pitted outwash and the prodelta deposits in the vicinity of Sand Lake. Blue clay reported in well records near Sand Lake (Cederstrom and Trainer, 1953, well $\operatorname{logs}_{\mathrm{s}} 46,69,80,83,93$, and 101) is interpreted by the authors as the Bootlegger Cove clay because of apparent continuity with, and similar altitude of, the surface of clay to the surface of the Bootlegger Cove clay. It extends under, and perhaps interfingers with, the delta and prodelta deposits (pl. 6). The Bootlegger Cove clay is re-exposed south of Jewel Lake, where it covers parts of secs. $11,13,14,15$, and 25 in T. 12 N., R. $4 \mathrm{~W}$. in the lowland adjacent to Turnagain Arm. The clay probably extended southwestward before erosion along the Arm truncated the southwestern edge of the clay. Two hills of ground moraine, flanked by stratified sand and gravel mapped as part of the glaciofluvial ice-contact deposits, stand above the level of the clay; the clay may overlap the till, and may be overlapped by the sand and gravel, but these relationships were not seen in the field. The till hills may be part of the moraine of Naptowne age from Turnagain Arm, as discussed under the section on the Knik ground moraine, and overlie the Bootlegger Cove clay. The lack of a coating of Bootlegger Cove clay over the surface of the till hills, which are below the level of the lake necessary for the deposition of the delta deposits, may be explained if the till hills are younger than the Bootlegger Cove clay. The clay is covered by swamp deposits to the east of the hills of till, but about three-fourths of a mile east of the till hill at the west end of Klatt Road an auger hole penetrated the clay.

A light-gray clay exposed along the Seward to Anchorage Highway, about three-fourths of a mile southeast of Little Rabbit Creek, is mapped as Bootlegger Cove clay. Another exposure of clay underlies 73 feet of till in the bluff about one-fourth mile north of Potter. This exposure is in a nearly vertical bluff and is not shown on plate 1; it may not be part of the Bootlegger Cove clay.

The Bootlegger Cove clay apparently overlaps or interfingers with the delta deposits beneath peat and muskeg along a line that is more or less parallel to the rise of the highland between Point 
Woronzof and Point Campbell, as shown along Knik Arm near the drainage outlet in sec. 22, T. 13 N., R. 4 W. The upper surface of the Bootlegger Cove clay extends almost horizontally along most of the bluff of Knik Arm. The materials that overlie the Bootlegger Cove clay range from peat near Point Woronzof, Naptowne outwash sand and gravel that extends northward from a point about 11/4 miles east of Point Woronzof to the Elmendorf Moraine, to sand and gravel of the Naptowne advance outwash, and gravelly till of the Naptowne ground moraine north of the Elmendorf Moraine. Springs and seeps along the upper surface of the Bootlegger Cove clay cause slumps and earthflows (Varnes, D. J., 1958) along Knik Arm. Scarps with slickensided surfaces are common on the Bootlegger Cove clay near the top of the bluff; hummocky earthflows are abundant at the foot of the bluff along Knik Arm. The measured slope on the Bootlegger Cove clay in most places along the bluff is about $30^{\circ}$ to $35^{\circ}$.

South of Jewel Lake, the surface of the Bootlegger Cove clay forms a relatively flat bench from Campbell Creek south to Turnagain Arm. A kettle and small lake interrupt the evenness of the generally horizontal surface. At the east end of the deposit, the surface gradually slopes beneath a swamp. Moderately steep banks confine Campbell Creek through the clay.

The Bootlegger Cove clay is a light-gray to dark-greenish-gray silty clay that contains layers or lenses of medium sand. The clay is hard and compact, breaks with a conchoidal fracture when dry, and is soft and sticky when wet. Beds one-fourth inch to 2 inches thick are visible in undisturbed samples, and laminations ranging from $0.25 \mathrm{~mm}$ to $1.0 \mathrm{~mm}$ thick commonly show within the larger beds. The laminations as well as the beds appear to be cyclic and to consist of alternating light-gray and dark-gray laminae and represent differences in the ratio of silt-size particles to clay-size particles in individual lamina. The particle-size similarity between the Bootlegger Cove clay and other samples is shown in figure 3.

The upper 12 inches commonly is a yellowish-gray silt that becomes more sandy in the upper 6 to 8 inches. Sand grains are scattered throughout the clay and angular pebbles 1 inch in diameter are common.

The Bootlegger Cove clay is best exposed along Knik Arm west of Bootlegger Cove and Chester Creek. A typical section of the Bootlegger Cove clay was prepared from sections exposed along the bluff of Knik Arm. In addition, an exceptionally thick exposure of the clay was measured near Cairn Point. 


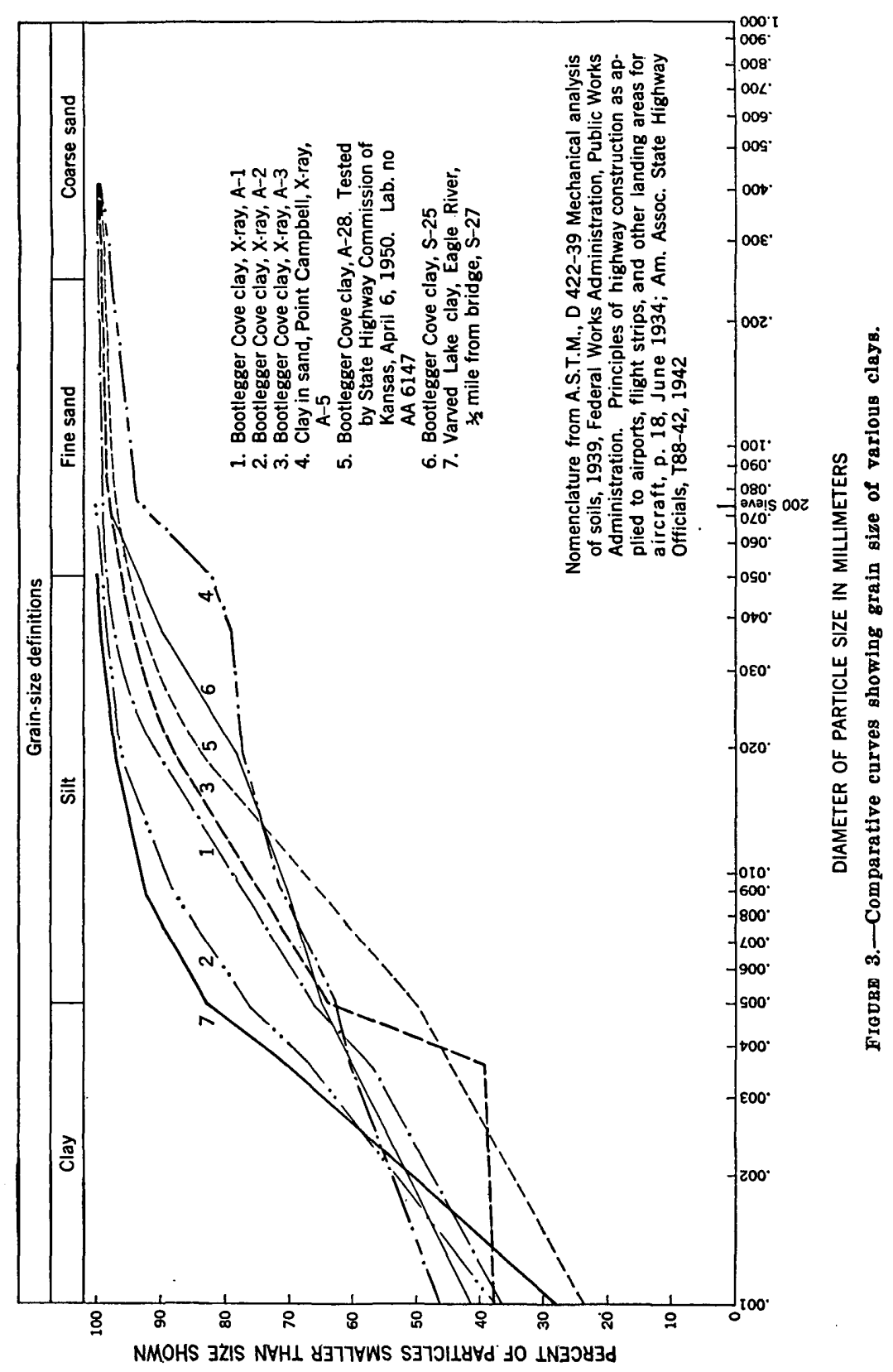


3. Composite section along the bluff of Knik Arm in the SW1/4 NE1/4 sec. 2S, T1S N., R. $4 \mathrm{~W}$.

Outwash of Naptowne age:

9. Sand, silty with humus; oxidized yellowish gray $(5 Y 6 / 2) \ldots \ldots . .16$

8. Sand, fine to medium, contains fine gravel in lenses; gray, some layers oxidized brown; fluvial crossbedding, beds 1 foot thick; coal fragments scattered throughout, locally concentrated into layers. Contact with Bootlegger Cove clay is sharp and hori-

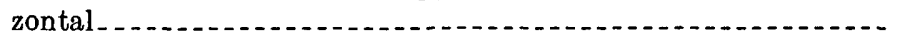

Bootlegger Cove clay:

7. Clay, silty, light-gray (N 7) dry to dark-greenish-gray (5 GY 4/1) moist; upper 12 inches oxidized yellowish gray (5 $Y 6 / 2$ ), lower limit oxidation even and distinct, no mottling below upper 12 inches; upper 6 to 8 inches more sandy ; plastic when wet, compact when dry; breaks with uneven hackly fracture. . . . . . . . . . . . .

6. Sand, medium, dark-greenish-gray (5 GY 4/1) moist.........

5. Clay, light-gray $(N 7)$ when dry to dark greenish gray (5 $G Y 4 / 1)$ when moist; compact, breaks with uneven fracture.............

4. Sand, medium, dark greenish-gray (5GY4/1) when moist........

3. Clay, silty, dark greenish-gray (5GY 4/1) when moist; grades into underlying clay

2. Clay, silty, light-gray $(N 7)$ when dry to dark greenish gray (5GY 4/1) when moist; compact when dry, plastic when wet..... $6 \quad 0$

1. Slump and flow debris to beach level................ 100

Total thickness

4. Thick section of Bootlegger Cove clay measured along ravine near Cairn Point, in the NW1/4SW1/4SE1/4 sec. $31, T .13 N$., R. $3 W$.

4. Silt, sandy, pale-brown (5 YR 5/2), humic

0 to 7 Glacial till:

3. Silt, sandy to gravelly, yellowish-gray (5 $Y 6 / 2$ ); compact; contains irregular lenses of sand and gravel, somewhat distorted; large erratics locally

110

Bootlegger Cove clay:

2. Clay, silty, light-gray $(N 7)$ when dry, to dark greenish gray (5 GY 4/1) when moist; plastic when wet, compact when dry; horizontally banded and laminated in $0.25 \mathrm{~mm}$ to 2 -inch layers; angular pebbles scattered throughout; upper surface not well exposed, but alinement of seepage and springs suggests irregular contact. . . . . . .

Tidal beach:

1. Clay, silty to sandy, dark-greenish-gray (5 GY 4/1); sticky, plastic; surface covered by erratic boulders of graywacke and greenstone that range from 1 to 6 feet in the longest dimension. Overlaps Bootlegger Cove clay

Total thickness 


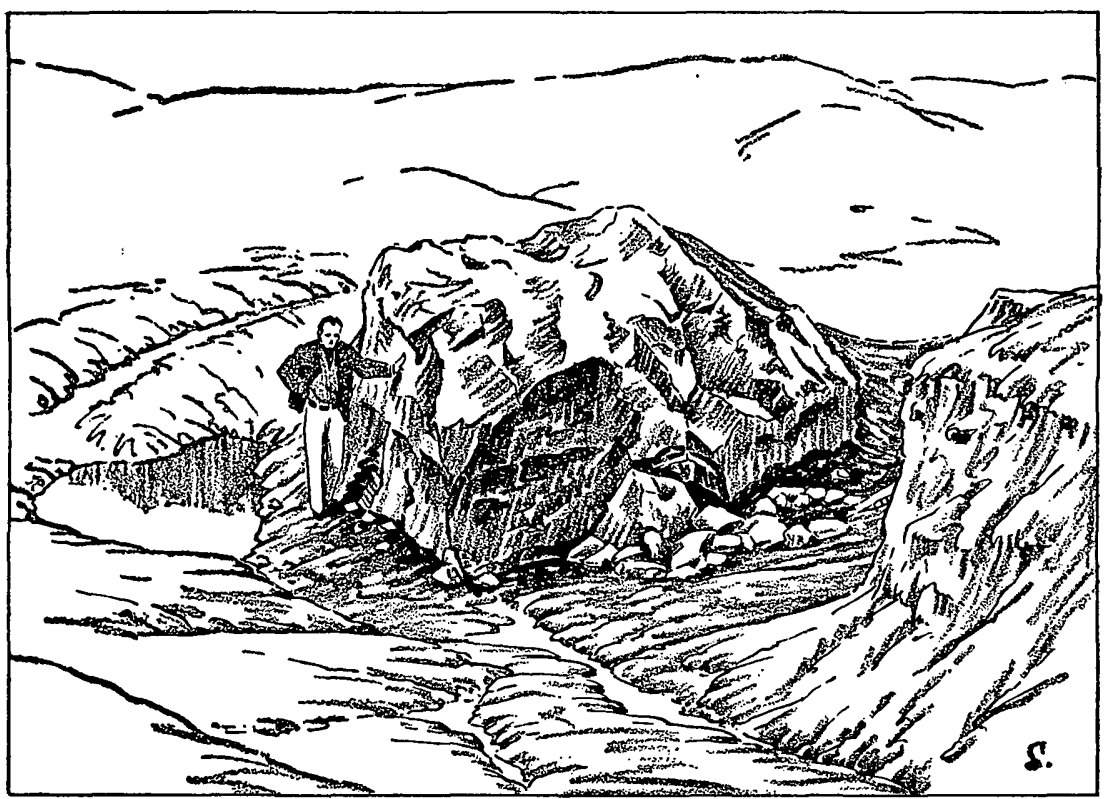

FroURE 4.-Erratic boulder in Bootlegger Cove clay south of Sand Lake Road, near center of sec. 14, T. 12 N., R. 4 W. Sketched from a photograph.

The 126-foot thickness of clay is inconsistent with thicknesses observed in other exposures, and an attempt to recover the exposure in 1956 failed. Trash and debris filled the ravine and covered the sea bluff at Cairn Point so that the till and clay were obscured. Exposures north and south of Cairn Point contain the Bootlegger Cove clay that extends about 30 to 50 feet above high tide.

Blue-gray silt and fine sand in the SE $1 / 4$ sec. 21 , T. 13 N., R. 4 W., overlies tan silt and sand of the delta. The blue-gray silt and fine sand is considered to be a coarse phase of the Bootlegger Cove clay and the two intergrade eastward along the bluff.

In the area south of Jewel Lake the Bootlegger Cove clay is light gray when dry and a dark greenish gray when wet. Compact and hard when dry, the clay is sticky and soft when wet. The upper 4 to 6 feet is oxidized to a yellowish gray $(5 Y 7 / 2)$ when dry, and light olive gray (5 $Y$ 5/2) when wet. Angular pebbles are scattered throughout the clay, but cobbles and boulders are rare. In 1955 , an excavation near the center of sec. 14, T. 12 N., R. 4 W. exposed oxidized clay that had a weak granular structure and displayed no layering that could indicate cyclic deposition. An erratic in the center of the excavation measured roughly 14 by 10 by 8 feet (fig. 4). This erratic boulder is the largest seen by the authors in the Bootlegger Cove clay, and must have been rafted on glacial ice. Near the edge of the bluff along Turnagain Arm, the lower 4 feet 
of excavations examined in 1956 show 4- to 6-inch layers of greenish-gray fine sand alternating with 1-inch layers of a tight plastic clay. Two feet of plastic dark-greenish-gray clay overlies the 4 feet of sand and clay. No oxidation was noted at this excavation.

One-half of a mile south from the Sand Lake Road along the west section line of sec. 14, T. 12 N., R. 4 W., a road cut exposed a block of yellowish-gray silty clay faulted downward into a poorly sorted gravel. Drag along normal faults was well developed. The silty clay shows laminae approximately horizontal, and contains pebbles, especially in the lower part near the underlying gravel. The clay in this exposure looks very much like an ice-contact deposit. The underlying gravel is very poorly sorted and consists of silt to boulder-size particles.

In the exposure three-fourths of a mile southeast of Little Rabbit Creek the Bootlegger Cove clay is a compact light-gray (dry) to plastic dark-greenish-gray (moist) silty clay. The clay is about 20 feet thick; the lower 11 feet is a plastic "blue" silty clay, the upper 9.5 feet is a sandy clay that becomes increasingly sandy near the top. The contact between the two parts of the clay is gradational.

Sample $A-6$ was collected at this exposure, and the similarity between the clay in this exposure and the Bootlegger Cove clay elsewhere can be seen by comparing sample $A-6$ with sample $A-2$ in table 2. The similarity in particle size is shown in the particle size curve on figure 3 .

Along the bluff in the middle of sec. 25, T. 13 N., R. 4 W., the Bootlegger Cove clay is 58 feet thick, the right order of thickness for most exposures. The maximum observed thickness is at Cairn Point, where 126 feet of light-gray silty clay is exposed. A well drilled in Turnagain Heights (Cederstrom and Trainer, 1953, No. 50) near the sea cliff where the Bootlegger Cove clay is exposed to beach level penetrated 117 feet of the clay. The maximum thickness of the Bootlegger Cove clay in the Anchorage area may be in excess of 250 feet. A well near the road forks near Lake Spenard (Cederstrom and Trainer, 1953, No. 80) penetrated 269 feet of silt and clay-interpreted by the authors as the Bootlegger Cove claybefore reaching the underlying gravel. The Bootlegger Cove clay was deposited blanketlike in all directions from the type area. Along its eastern and southern margins it appears to thin out or abut against the edge of the basin of the Susitna Valley. The fine siltand clay-size particles that comprise the Bootlegger Cove clay were derived from rock flour transported by glacial melt water. The loads probably. were similar to those carried by modern glacial streams. The Matanuska, Knik, and Eagle Rivers carry silty clay (rock flour) from the glaciers at their sources to Knik Arm. At low 


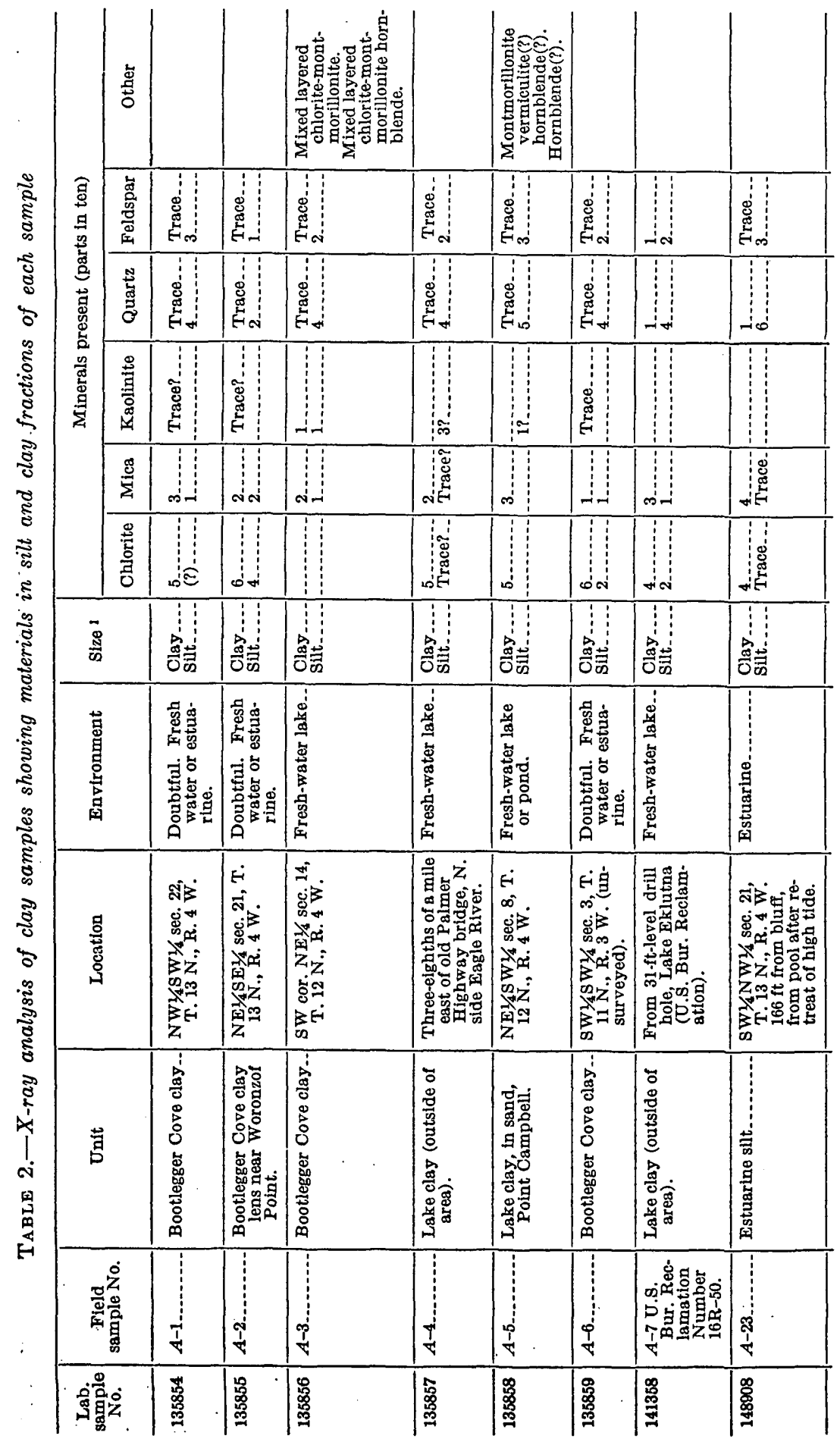




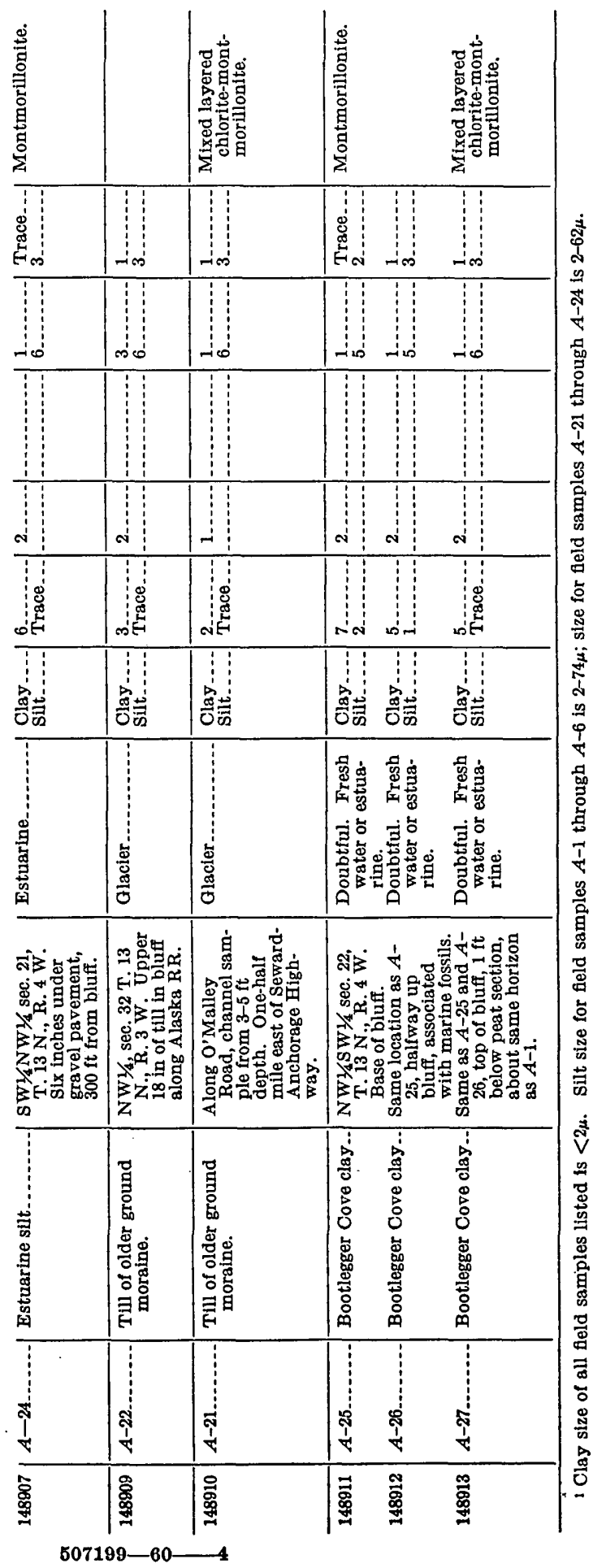


tide this blue-gray estuarine silty clay is exposed from bluff to bluff across the Arm. Whether the Bootlegger Cove clay was deposited in an estuary or in a fresh-water lake is not conclusively known. Facts that support a lacustrine or an estuarine environment are discussed below.

The Bootlegger Cove clay overlies deposits of the delta, and in the SE1/4 sec. 21, T. 13 N., R. 4 W., a blue-gray silt and sand phase of the Bootlegger Cove clay overlies and appears to interfinger with the delta deposits. If these two deposits are contemporaneous, as the authors believe, the Bootlegger Cove clay must be a glacial deposit; if the deposits are not contemporaneous, the Bootlegger Cove clay may be, but must not necessarily be, an interglacial deposit.

The Bootlegger Cove clay and the delta may have been deposited contemporaneously from the same source into a glacial lake. The Bootlegger Cove clay then would have accumulated as bottomset beds of the delta. This explanation is not acceptable because the lateral extent of the clay, north and east from the margin of the delta, the horizontal surface of the clay, the constancy of percentages of particle sizes in the clay, and the similar altitude of the clay above sea level combine to suggest that the clay is not a bottomset deposit.

Another possibility is that the delta formed in a glacial lake that was drained prior to deposition of the Bootlegger Cove clay, which accumulated either in a later lake that reoccupied the basin, or in an estuary that formed as the sea encroached on the drained-lake area. Drainage and refilling of a lake basin is required by this explanation. The ice-contact features in the clay along Campbell Creek, the weathered upper surface of the clay, and the large icerafted boulder, all discussed earlier, suggest deposition of the Bootlegger Cove clay in a glacial environment. The delta and prodelta deposits are associated with features that necessitate stagnant blocks in the area during deposition and indicate a late phase glacial deposit. Drainage of the lake basin prior to deposition of the Bootlegger Cove clay requires reoccupation by a second lake during the same part of a glacial substage. To make these events possible, the glacier blocking the Inlet had to retreat; deltaic deposition ceased; the delta was eroded, the lake drained, and the basin was refilled. Such refilling by another lake in the same glacial stage in which the Bootlegger Cove clay was deposited is inconsistent with the authors' interpretation of late-stage glacial activities.

The Bootlegger Cove clay was accepted as an estuarine deposit for many years. In 1950, the authors were of this opinion and based their decision on fossils that have similar present-day forms col- 
lected by Miller and Cooley along the bluff in secs. 22 and 23, T. 13 N., R. 4 W. F. Stearns MacNeil identified them as:

\section{Buccinum cf. B. physematum Dall \\ Odostomia (Evalea) sp. \\ Nuculana fossa Baird \\ Cardium ciliatum Fabricius \\ Macoma cf. M. sabulosa Gmelin \\ Saxicava pholadis Linné \\ Mya truncata Linné}

Collecting records in the Distributional list of the West American Marine Mollusks, the Conchological Club of Southern California, indicate that Nuculana fossa Baird, Cardium ciliatum Fabriciuss, Saxicava pholadis Linné, and Mya truncata Linné have been dredged from relatively shallow waters; that is, 10-75 fathoms. Mya truncata has been collected from intertidal mud flats. (F. Stearns MacNeil, oral communication, January 1957.) The bluff line is an area of almost continuous slump and although utmost care was taken in collecting the fossils, the authors doubt if the fossils were in undisturbed materials and in place. In July 1956 the authors and W. R. Hansen revisited the locality and although many individual shells were found in the slumps and earthflows that extend along the bluff of Knik Arm, no specimens could be found in material that was unquestionably undisturbed, or was even high enough to be unaffected by storm waves or winter shore ice.

F. W. Trainer (written communications, dated Sept. 18, 1956, and Jan. 17, 1957) of the U.S. Geological Survey, however, does consider shells he collected from the same bluff line to have been in place in undisturbed material and that the Bootlegger Cove clay is at least in part estuarine in origin. The height of the surface of the Bootlegger Cove clay above modern sea level is explained if the waters of the Cook Inlet were higher during the interval of deposition. If, however, the sea level was no higher than the present level, rebound of the surface in post-Wisconsin time could have raised the Bootlegger Cove clay to its present position. Recent differential uplift has been reported at different places along the Alaskan const (Smith, P. S., 1909, p. 278; Buddington, A. F., 1927, p. 52 ; and Twenhofel, W. S., 1952).

Deposition of the Bootlegger Cove clay in an estuary requires retreat of the glacier blocking Cook Inlet, erosion of the glacial lake, and encroachment of the basin by the sea. If the Bootlegger Cove clay was an estuarine deposit, sea water covered the lowland behind the delta. During this time, the glaciers to the north remained close and provided the ice-rafts for boulders, such as the one south of Jewel Lake. Rock flour in the melt water was depos- 
ited in slack water much as rock flour is being deposited in the modern Knik and Turnagain Arms. Reworking of the delta by waters of Cook Inlet would result in apparent interfingering between the Bootlegger Cove clay and the delta deposits.

The differential glacial retreat, erosion, lake drainage, and encroachment by the sea, all taking place during the last part of the Knik glaciation does not seem feasible. If the Bootlegger Cove clay is considered to be an interglacial deposit rather than a lateglacial deposit, the ice-contact features and large ice-rafted boulders that suggest a glacial environment can not be explained by accumulation as either a lacustrine or estuarine deposit.

Beds and laminations in the Bootlegger Cove clay exposed near Cairn Point may be varves, or annual laminations. The beds appeared to be graded within each unit during field examination, but no detailed analysis was made. If varves, they would almost necessitate a fresh-water environment inasmuch as clays flocculate in sea water and are deposited as a massive deposit (Twenhofel, 1939, p. 499).

Seven samples were tested for similarities or differences that might be diagnostic of the depositional environment (table 2). Hathaway and Parker of U.S.G.S. (written communication, September 1954), report that "*** All of the samples except $135856(A-3)$ show essentially the same composition. The presence of chlorite may indicate an environment with relative high $\mathrm{pH}$. This together with the general scarcity of kaolinite group minerals suggests a marine environment, although as glacial materials, the clays may have undergone little change from their original composition and therefore not reflect their environment adequately. *** The presence of montmorillonite interstratified with chlorite in sample 135856 (A-3) suggests an environment of relatively lower pH." After analyzing sample $A-7$, they reported (written communication, June 1955) "*** Samples $A-1$ through $A-5$ all show interstratification of chlorite and montmorillonitic layers which in sample $A-3$ reaches a degree that gives the $\mathrm{X}$-ray pattern an appearance similar to that of vermiculite. The samples could be grouped as follows on the basis of the chlorite characteristics":

Increasing mixed layering [of chlorite and montmorillonite]

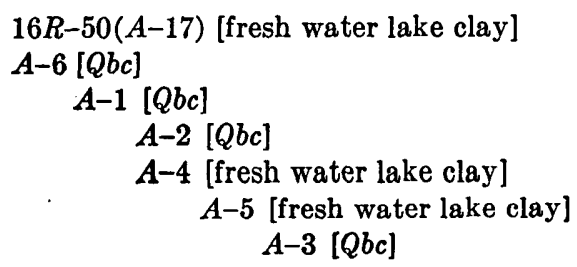


The samples are grouped above to show the trend toward interstratification of chloritic and montmorillonitic layers. Indications of the types of materials have been inserted for clarity. High chlorite content could indicate a marine environment, and high mixed layered mineral content (sample $A-3$ ) a fresh-water environment. At the chloritic end of the sample grouping, however, as well as at the mixed layered end, are samples of fresh-water deposits; that is, samples $A-7, A-4$, and $A-5$, and a trend toward a marine environment of samples $A-1, A-2$, and $A-6$ must be discounted to a large extent. Hathaway and Parker also emphasize that surface weathering of the source rock before redeposition as rock flour could produce the montmorillonite layers in the mineral particles. In addition, the silty clay in all the samples was derived from chlorite-rich rocks-greenstone and graywacke-and the presence of chlorite in the samples would not necessarily indicate a marine environment. Of interest is the thesis by R. W. Stump, on file at Iowa State College, in which he concludes that the clay mineral in the Matanuska Valley loess is dominantly chlorite derived from parent rocks and was uninfluenced by soil-forming processes (written communication, 1956).

Additional clay samples collected in 1956 were analyzed by J. C. Hathaway, H. C. Starkey, and Gillison Chloe, in a further attempt to determine the depositional environment of the Bootlegger Cove clay. Samples of known estuarine silt were compared to the Bootlegger Cove clay (table 2). The differences between the estuarine samples $(A-23, A-24)$, the fresh-water clays $(A-4, A-5, A-7)$, and the Bootlegger Cove clay ( $A-1, A-2, A-3, A-6, A-25, A-26, A-27$ ) are too small to verify the environment of the Bootlegger Cove clay. The montmorillonite and mixed-layered minerals in the Bootlegger Cove clay are only traces and, according to the analysts, could have developed through weathering of the material at its source rather than through marine diagenesis.

Angular pebbles and occasional boulders scattered throughout the clay indicate deposition by glacial ice rafting. Lake ice transport of a 10 by 14 foot boulder does not seem feasible. Further support for a glacial environment during deposition of the Bootlegger Cove clay is in sec. 14, T. 12 N., R. 4 W. Bootlegger Cove clay, exposed in a road cut along the south bank of Campbell Creek, is downfaulted into a poorly sorted gravel. It appears that at this point the Bootlegger Cove clay was in contact with glacial ice. North of Anchorage, a clay interpreted as the Bootlegger Cove clay, is recorded in the log of the West Power Plant well (Corps of Engineers, unpublished well logs) with sand, gravel, and till interlayered with the clay between the depths of 208 and 236 feet. In addition, 
oxidation of the upper 18 to 24 inches of the Bootlegger Cove clay strongly suggests deposition during a glacial stage and weathering during an interglacial stage. Everywhere the Bootlegger Cove clay was observed to be oxidized the clay was overlain by deposits of the Naptowne glaciation; that is, the outwash, pitted outwash, end moraine, advance outwash, or ground moraine. A sufficient time interval apparently was available for oxidation between the deposition of the Bootlegger Cove clay and the subsequent deposition of the Wisconsin glacial deposits.

In the absence of conclusive evidence, the depositional environment of the Bootlegger Cove clay is not established, but the authors: favor the view that the clay was deposited in a fresh-water glacial lake. The following hypothesis that fits most of the facts available is presented with the realization that no one theory of deposition known to the authors is completely satisfactory in all details. Part of the pre-Wisconsin Matanuska-Knik Valley glacier apparently stagnated and covered the area with blocks of ice as large as 1 mile in diameter. The active ice of this glacier was north of the area. The glacier blocking the Cook Inlet south of Anchorage dammed the southward flowing melt water and formed the lake into which the delta and prodelta deposits accumulated from the southwest, and the rock flour accumulated from the north. The silt, sand, and gravel of the delta and the clay of the Bootlegger Cove clay encroached toward each other. Two separate source areas would explain the separation in grain size where the Bootlegger Cove clay overlaps or interfingers with the delta. The thickness of the clay depended on the proximity of the delta as well as the position of the margin of the depositional basin. The thinness of the clay south of Jewel Lake suggests that deeper water lay off what is now Point Woronzof, and shallow water lay off what is now the Jewel Lake area. The lake probably extended up Turnagain Arm for an unknown distance, but the deposits were eroded except for the remnants near Little Rabbit Creek and Potter.

\section{GLACIOFLUVIAL ICE-CONTACT DEPOSITS}

Hills and ridges stand above the level of the ground moraine and display in section stratified and crossbedded moderately dipping beds of silt, sand, pebbles, and cobbles. The hills and ridges have steep depositional ice-contact slopes. All of the ice-contact features have similar depositional characteristics; the deposits are sorted and usually stratified, they show fluvial deposition, they show abrupt changes in grain size in adjacent layers, and they are deformed. The knobs, hills, and ridges-kames and eskers-are prominent constructional features, but they are not mapped separately. They are 
grouped instead, as glaciofluvial ice-contact deposits. The boundary between this group of deposits and the ground moraine is approximately located in the area around O'Malley and Huffman Roads, where the gray sand and gravel of the glaciofluvial ice-contact deposits overlie the ground moraine in sufficient thickness ( +4 feet) or in knobs and ridges numerous enough to warrant differentiation from the underlying till of the ground moraine.

Two major areas of accumulation of the glaciofluvial ice-contact deposits are south of Ship Creek adjacent to the lateral moraine, and between O'Malley and Huffman Roads east of the SewardAnchorage Highway. Other deposits are along Tudor Road near Otis Road, from Goose Lake northeast to Walton Road, near the Campbell Airstrip, and near the edge of the bluff along Turnagain Arm south of the Sand Lake Road. Smaller kames and eskers are scattered throughout the lowland, but because of the map scale they are not shown.

The glaciofluvial ice-contact deposits consist almost entirely of conical or knoblike kames and a few sharply terminated sinuous eskers. The slopes of the knolls are smooth and in places are as steep as $30^{\circ}$. Between O'Malley and Huffman Roads the glaciofluvial ice-contact deposits form a low hummocky terrain composed of small ridges and mounds 4 to 10 feet high, and a general formless cover of fluvial debris. The glaciofluvial ice-contact deposits consist of rock rubble, fluvial, lacustrine or deltaic deposits. Piles of rock rubble, stratified deposits with horizontal or steeply dipping layers, silt and clay with ripple marks overlying coarse sand and pebble gravel, and contorted beds of interlayered silt, sand, and gravel comprise-separately or in combination-many of the hills in the lowland. Many small ridges or hills similar in shape to kames and eskers are composed of till of the ground moraine. In the Lake Otis Road-Tudor Road area, road cuts expose contorted stratified silt and sand and some pebble gravel. Steep slopes separate the glaciofluvial ice-contact deposits from the swamp area. Road cuts likewise provide most of the exposures in the ridges between Goose Lake and Walton Road, where the ridges are composed of poorly sorted silty sand and gravel. A deposit at Bragow Road and DeBarr Road is a tight silty brown pebble and cobble gravel.

A kame field is on the eastern edge of the glaciofluvial ice-contact deposits south of Ship Creek. Many circular, elongate, and ridgelike tree-covered kames form a knob and basin topography. The kames here consist of contorted interlayered stratified silt, sand, and gravel. Extending into the NE1/4 sec. 25, T. 13 N., R. 3 W. from the SW $1 / 4$ sec. 19 and the NW1/4 sec. 30, T. 13 N., R. 2 W. (unsurveyed), this small kame field rises above the swamp that ad- 
joins it on the north and south sides. The boundary with the glaciofluvial ice-contact deposits on the west is distinct and steep, whereas a low hill of ground moraine abuts it on the east.

The materials in the O'Malley and Huffman Roads area range from moderately well-sorted sand and cobble gravel to poorly sorted sand and cobble gravel with horizontal to steep dips. In the $\mathrm{NW} 1 / 4$ NW $1 / 4$ sec. 16 , T. 12 N., R. 3 W., a road cut in a south-trending kame exposes concave bedding in sand interlayered with silt and gravel. The slight concavity of the layers suggests that only slight differential settling accompanied ice melting. Any great amount of settling would have contorted the bedding more than is seen in exposures.

Glaciofluvial ice-contact deposits in the area around O'Malley and Huffman Roads overlie the ground moraine, are bounded by swamps and pitted outwash, and, in addition, are locally cut and bounded by abandoned melt-water channels. Cuts along O'Malley Road show poorly sorted medium to coarse sand with stringers of gravel. The sand layers one-half to 3 inches thick alternate with silt layers one-eighth inch to one-fourth inch thick. A cut along the Alaska Railroad in the NW1/4 sec. 29, T. 12 N., R. 3 W. exposes gray crosslaminated ripple-marked sand and layers of silt. Layers of similarly cross-laminated and ripple-marked silt and sand are exposed along a cut in a side road that extends south from Huffman Road into the same deposit. Gravel lenses 6 inches below the surface overlie the ripple-marked and cross-laminated silt and sand. Twenty feet south along the road cut the sand is cross-laminated and cut and filled by additional layers of sand. Such features suggest changes in depositional environments that range from rapid flowing streams to slow moving streams or ponded waters.

One of the better exposures of kame structure is in a pit at the west end of O'Malley Road. The Seward-Anchorage Highway transects a kame of silt and sand interlayered with pebble and cobble gravel that dips from $27^{\circ}$ to $35^{\circ} \mathrm{SW}$. Some of the layers are truncated by less steeply dipping layers of sand and gravel. Underlying the northern part of the kame is clayey till 14 feet thick, exposed along the ditch line downslope toward a swamp. A block of till that overlies the stratified drift in the southwest part of the gravel pit points up the close association with the ice during deposition. A 1.5-foot layer of cobbles and small boulders, exposed south of the gravel pit during construction of the Seward-Anchorage Highway, show imbricate structure with an inclination of $55^{\circ}$ to the northwest. The cobbles and boulders overlie 14 feet of gray sand and pebble gravel, which contains occasional cobbles, that dips $25^{\circ}$ to the southeast. The dip and imbrication indicate streamflow from the northwest. 
In 1956, examination of a gravel pit in the kame on the east side of the Seward-Anchorage Highway, in the NW1/4NW1/4 sec. 20, T. 12 N., R. 3 W., revealed beds dipping about $20^{\circ}$. Layers of sand and pebble and cobble gravel parallel the surface slope of the kame ridge (pl. $7 A$ ). Overlying the sand and gravel is a tan silty sand that shows little evidence of slopewash or modification of the topography of the kame.

In the SE $1 / 4$ NE $1 / 4$ sec. 18, T. 12 N., R. 3 W., a low sinuous kame ridge (not mapped) about 600 feet long trends southward and overlies the ground moraine. A gravel pit in the south end of the ridge exposes (1956) silty pebble and cobble gravel (pl. $7 B$ ). Gravel layers alternate with layers of medium to coarse sand; lenses of silty fine sand and silt interfinger with the coarser materials. The silt and gravel layers are contorted with sandy silt layers bending upward into the gravel. Where this happens, the stratification of the gravel parallels the contortions. Such features are discussed under the Naptowne pitted outwash. Two small normal faults suggest deformation due to collapse as the supporting ice melted. Part of the pebble and cobble gravel is unsorted and silty, and appears to grade into till. In this pit the bedding is not parallel to the slope of the kame surface.

A pit at the west end of Klatt Road exposes horizontally layered silt, sand, and gravel, which contains scattered cobbles overlying silty boulder till. In general, the gravel is sorted so that the coarser material, near the contact with the till, grades upward into pebble gravel containing some cobbles. About 18 inches below the surface, there is a sharp change in sorting; the upper 18 inches is a gray sandy pebble gravel and has fewer cobbles. The gravel covers the flanks of the till mounds and perhaps accumulated as slopewash from the till of the ground moraine. The deposit may not, therefore, be a true kame. Nevertheless, the gravel is included as part of the glaciofluvial ice-contact deposits.

In most places road cuts expose only the upper 6 to 12 feet of the glaciofluvial ice-contact deposits. In the southwest corner of the NW1/4NW1/4 sec. 20, T. 12 N., R. 3 W. a drilled well was still in sand at the depth of 45 feet. The gravel pit in the kame ridge in the $\mathrm{NW} 1 / 4 \mathrm{NW}^{1} / 4$ sec. 20, T. $12 \mathrm{~N}$., R. $3 \mathrm{~W}$. exposes a thickness of about 50 feet. Exposed thicknesses of the glaciofluvial deposits greater than 50 feet are not known elsewhere in the lowland. Many of the deposits over the ground moraine along O'Malley Road are thinner, ranging from a featheredge to about 30 feet in thickness. The glaciofluvial ice-contact deposits accumulated on the surface of the active ice or around blocks of stagnant ice that covered the lowland. Some of the glacial debris was deposited as unsorted to 
slightly sorted rubble in crevasses. Streams flowing on and between blocks of stagnant ice left fluvial deposits in crevasses and thaw depressions in the ice or older ground moraine. Not all the fluvial deposition was by streams of similar or constant velocities. The ripple-marked sand and silt and the concave-bedded sand indicate a shallow stream or slack-water environment, whereas deposits that have steep dips and rapid change of texture suggest fluvial or deltaic deposition.

As the Anchorage area was deglaciated, the glaciofluvial icecontact materials were deposited over the ground moraine. Streams flowing under the ice or between the ice and the lateral moraine deposited kames and eskers south of Ship Creek. In the lowland, streams flowing partly on the ice and partly on the ground moraine deposited the glaciofluvial ice-contact deposits as kames, eskers, and crevasse fillings, or merely as a covering of sand or pebble and cobble gravel over the till of the ground moraine. Melt waters from ice in the lowlands incised channels into both the ground moraine and the glaciofluvial ice-contact deposits, indicating that the glaciofluvial ice-contact deposits are products of the same glaciation that deposited the ground moraine; that is, the pre-Wisconsin Knik glaciation.

The glaciofluvial ice-contact deposits were derived from debris that accumulated on the surface of the glacier and was carried from the north into the Anchorage area. As the glacier thinned, this debris covered the surface of the glacier, and was reworked and redeposited by streams flowing partly on the ice and partly on the ground moraine.

\section{PITIED OUTWASH}

Overlying the ground moraine in the lowland south of Anchorage are deposits of sand and gravel that are horizontally stratified, cross-laminated, and locally distorted. The surface is generally horizontal, but it is modified by swamp-filled kettles and low hills. "Though many gradients probably controlled deposition, two cycles or sequences of deposition are mapped based on relative altitudes of the depositional surfaces; the older cycle has a higher depositional surface, and the younger cycle has a lower depositional surface. Deposits of the older cycle of deposition are restricted to areas south of Spenard and south of Lakes Hood and Spenard. Extending from Lakes Hood and Spenard the pitted outwash, sequence 1, continues almost to the Sand Lake Road east of Jewel Lake. One other area of the pitted outwash, sequence 1, extends from south of Spenard to beyond Tina Lake. The pitted outwash locally bounds the delta, Naptowne silt, and the prodelta deposits south of Lakes Hood and Spenard. 
South of Spenard the pitted outwash, sequence 1, locally adjoins the Naptowne outwash, Naptowne pitted outwash, and the pitted outwash, sequence 2. The greater part of the pitted outwash, sequence 1 , is bounded by areas of peat and muskeg-filled swamps.

Deposits of the younger cycle, pitted outwash, sequence 2, cover parts of the lowland south of Anchorage from near Ship Creek to Turnagain Arm. The preponderance of deposits of the pitted outwash, sequence 2, parallel Campbell Creek and extend from the Campbell Airstrip to Turnagain Arm.

The surfaces of the pitted outwash gradually slope to the southwest. Kettles and low hills locally disrupt the continuity of the surfaces. The pitted outwash, sequence 2 , forms low mounds that locally abut against till of the ground moraine in the swamp areas. North along the road from Campbell a series of four terracelike surfaces are developed. The highest surface is at the top of the hill north of the crossing on the Alaska Railroad. In the area east of Rogers Park, erosion by waters that deposited the Naptowne pitted outwash cut straight smooth scarps into most of the deposits of pitted outwash. In the area south from Spenard to Turnagain Arm, deposits of the pitted outwash display steep smooth icecontact slopes around the swamp-filled kettles. The pitted outwash consists of fluvially stratified sand and gravel that is olive gray (5 $Y 3 / 1$ ) when dry and a deep hue of olive green (5 $Y$ 4/2) when wet. Medium sand to pebble gravel comprise the pitted outwash, although fine sand and coarse gravel comprise the deposits locally. Dips in excess of $20^{\circ}$ and contorted bedding are common near the kettles that pit the surface of the outwash. Oxidation is confined to the upper 18 inches in most exposures.

The pitted outwash, sequence 1 , is typically exposed in a pit in the NE $1 / 4$ sec. 36, T. 13 N., R. 4 W. Twenty feet of fine gravel and medium sand are interfingered with coarse gravel. Fragments as large as 12 inches in diameter are included in the deposits. An oxidized brown silty soil one foot thick overlies the gravel. Along the Sand Lake Road east of Jewel Lake the pitted outwash consists of subround to subangular medium to coarse olive-gray sand in which pebbles are scattered. Oxidation extends down about 8 inches from the surface. A gravel pit south of the cemetery in the SE $1 / 4$ sec. 19, T. 12 N., R. 3 W. exposed a sandy pebble gravel. Eleven to 14 feet of crossbedded gravel beneath about 4 feet of well-sorted fine sand is exposed in a pit in the NE1/4 sec. 8, T. $12 \mathrm{~N}$., R. $3 \mathrm{~W}$. Some distortion and collapse suggest close proximity of ice during deposition. Distortion in the sand and silt layers in the pitted outwash, sequence 2, in an exposure along Klatt Road also is attributed to collapse. 
Differences in maximum altitudes of the upper surfaces of the pitted outwash deposits suggest a changing gradient of deposition. From Campbell Station northward, four well-defined surfaces are developed and indicate at least four gradients of the outwash stream. Near the west end of O'Malley Road, the upper surface of the kame in the $N W 1 / 4 \mathrm{NW}^{1 / 4}$ sec. 20 , T. $12 \mathrm{~N}$., R. $3 \mathrm{~W}$., the surface of the pitted outwash south of the cemetery in the SE1/4 sec. 19, T. $12 \mathrm{~N}$, R. $3 \mathrm{~W}$., and the surface of the pitted outwash north of the cemetery suggest at least three gradients or base levels during deposition of the stratified drift in the lowland. A closer or more detailed study of the levels of deposition cannot be made from the topographic mapping available ( 50 -foot contours), but changing gradients would be expected where 1) channels extended around blocks of ice and were of different lengths, 2) the amount of flow of the melt water fluctuated abruptly, or 3) the source of the melt water slowly moved northward behind a zone of stagnant ice and thereby increased the length and lowered the gradient of the melt-water channel.

Steep well-developed ice-contact slopes resulted from collapse of the deposits along the contact between the outwash and the ice in the NE $1 / 4$ SW $1 / 4$ sec. 24 , T. 12 N., R. 4 W., and in the eastern part of secs. 2 and 11, T. 12 N., R. 4 W. Small lakes such as Sand Lake, Sundi Lake, Jewel Lake, Connors Lake, Campbell Lake, and others, are remnants of larger lakes partly filled by peat and muskeg.

The waters that deposited the pitted outwash may have modified the prodelta deposits. The horizontal bedding in the upper few feet of the prodelta deposits exposed near Jewel Lake suggests such a reworking. The blocks of ice against the prodelta deposits still remained, although they were perhaps somewhat reduced in size when the pitted outwash was deposited, as indicated by a continuous ice-contact slope in both deposits around a swamp-filled kettle, in sec. 10, T. 12 N., R. 4 W. The pitted outwash deposits were derived from debris carried in and on the Knik glacier. Melt water from the zone of ice actively retreating to the north and the lesser amount from the blocks of stagnant ice in the Anchorage area deposited the outwash over earlier deposits and around blocks of ice. After deglaciation, kettles pitted the surface of the outwash.

\section{ABANDONED-CHANNEL DEPOSITS}

Melt-water streams deposited stratified sand, pebbles, and cobbles along wide channels incised into the Knik glacial deposits. The sand and pebble and cobble gravel in the channels are mapped as abandoned-channel deposits. The ground moraine, the glaciofluvial ice-contact deposits, and sequence 2 of the pitted outwash are cut by 
the abandoned channels in the area between Campbell Airstrip and Huffman Road. Most of the channels originate in depressions in the ground moraine, although a few of them originate in the glaciofluvial ice-contact deposits and pitted outwash deposits.

Abandoned-channel deposits are also at the mouth of Rabbit Creek.

The upper surfaces of the channel deposits are graded and level. The abandoned channels range from a few tens of feet to over 2,000 feet in width, and from 20 feet to over 50 feet in depth. They are sinuous and indirect, and contain small modern streams.

Most of the channel deposits are well sorted, but some are not. Where the melt-water stream flowed on or near blocks of ice, slumping or sliding has distorted the sand and gravel. In places, till is exposed where later erosion has cut into the abandoned-channel deposits; till associated with stratified sand, for example, is exposed along Rabbit Creek a few hundred feet upstream from the highway bridge in a cut along the old Anchorage-Potter Road. Some of the channel deposits are pebble and cobble gravel (pl. $8 A$ ), whereas others are chiefly sand. The particle size of the material deposited along each channel depends on the composition of the ground moraine along the melt-water stream, the gradient of the stream, and the distance from the source. Thus, the size of the particles in the abandoned channel deposits vary from place to place.

In most places the deposits are thin -4 to 12 feet thick-although channel deposits at the mouth of Rabbit Creek are about 22 feet thick. During stagnation of the ice the melt-water streams flowed partly on the ice and partly on the recently deglaciated ground moraine. The amount of debris carried by streams was small and probably did not decrease their cutting power as they left the stagnant ice. Downcutting by the streams increased their load, so that most of the abandoned-channel deposits were reworked from materials on which the streams flowed. The deposits on the floors of the scoured channels are veneers that were left as the discharge decreased.

The channels may have been cut by melt-water streams that originated from either the melting ice in the lowland, or from the melting ice of the retreating valley glaciers in the mountains. The authors believe that in most cases, the melt water came from a combination of the sources. Between Campbell Airstrip and O'Malley Road are examples of channels probably formed from stagnant ice in the lowland. An alluvial fan and abandoned-channel deposits of Wisconsin age obscure some of the relationships of these channels to the ground moraine.

The stratified sand and gravel in the abandoned-channel deposits at the mouth of Rabbit Creek were deposited by melt water from 
valley glaciers in Rabbit Creek. The increased width of the deposit at the mouth of the creek may be due merely to a widening of the channel, or the deposit may be the apex of an alluvial fan that was later eroded by the waters of Turnagain Arm. Horizontally bedded sand and fine gravel that overlie deposits of ground moraine in the road cut at the mouth of Rabbit Creek (pl. $8 A$ ), and along the bluff of Turnagain Arm, suggest deposition as an alluvial fan at the end of a melt-water channel.

\section{WISCONSIN DEPOSITS}

\section{DEPOSITS OF THE NAPTOWNE GLACIATION}

\section{STRATIGRAPHY OF THE NAPTOWNE DEPOSITS}

An unmapped blue-gray pebble and boulder till that overlies the Bootlegger Cove clay and underlies the younger Naptowne advance outwash exposed in the bluff along Knik Arm in the SW1/4 sec. 29, T. 14 N., R. 3 W., is the oldest Wisconsin glacial deposit in the area. The advance outwash is stratigraphically the lowest Naptowne glacial deposit mapped. An end moraine extending through the Elmendorf Air Force Base was deposited next. It grades into the ground moraine that covers most of the area north of the end moraine. Kame fields and kame terraces and alluvium in abandoned channels overlie the Naptowne ground moraine. In front of the end moraine are stratified deposits of outwash and pitted outwash, as well as a deposit of silt, all of which locally overlie the Bootlegger Cove clay.

\section{TOPOGRAPHY}

Topography of the ground moraine, kame fields and kame terraces, and the end moraine, all of Wisconsin age, is young in appearance. The pitted surface of the ground moraine is gently undulating, with low rounded hills and mounds. Most of the kettles are unfilled, or contain lakes or swamps. The kettles are not connected by modern stream channels. Drainage is not well integrated except along abandoned channels where small streams flow in large valleys. The channels trend southwesterly through the ground moraine and emphasize the striated appearance established by southwest-trending drumlins.

The kame fields and kame terraces behind the end moraine have a hummocky knob and kettle topography. Some kettles contain lakes, others contain swamps, and still others are unfilled. The ice-contact slopes are steep, smooth, and unmodified by erosion.

The end moraine is unmodified by glacial erosion. Kettles and kames cover its surface but it is modified locally by incised channels of abandoned melt-water drainages. 
Topographically, the deposits of the pre-Wisconsin Knik glaciation and the Wisconsin Naptowne glaciation are closely similar. Physiographic evidence does not indicate a long period of erosion or weathering between the deposition of the two drift sheets.

\section{AGE AND CORRELATION}

That an interglacial interval separates the Naptowne glacial deposits from the Knik glacial deposits, however, is indicated by the weathering and oxidation on the Bootlegger Cove clay, the peat development on the pre-Wisconsin Knik advance outwash, and the ecology of fresh-water gastropods from clays associated with the peat. The peat underlies the Naptowne advance outwash in an exposure in the south bank of the Eagle River in the SW1/4 SE1/4 sec. 9, T. 14 N., R. 4 W. The peat was dated as being more than 38,000 radiocarbon years old (W-535). Karlstrom (1950, in Péwé, 1953 , p. 4) considered the morainal belt at the mouth of the Matanuska Valley as deposits of the Naptowne glaciation of late Wisconsin age. The Elmendorf Moraine is part of this Naptowne morainal belt. In 1957 he recorrelated the Naptowne to represent all of Wisconsin time. Because of the evidence for an interglacial stage or substage, and the carbon-14 date, the Naptowne glacial deposits are considered younger than 38,000 years old, part of the Wisconsin glaciation (table 1), and are correlated with the Naptowne glaciation of Karlstrom (fig. 2). The relationships of the deposits of the Eklutna, Knik, and Naptowne glaciations, are shown in plate 9.

\section{ADVANCE OUTWASH}

The stratified sand and pebble and cobble gravel that overlies the Bootlegger Cove clay and underlies the ground moraine along Knik Arm is considered to be an outwash deposited in front of the advancing Wisconsin glacier and subsequently overriden by the glacier. The advance outwash is exposed almost continuously northeastward from Cairn Point in the bluff along the east shore of Knik Arm, where it overlies the Bootlegger Cove clay. This outwash appears to terminate in the disturbed area near Cairn Point. Sand and gravel that may be the advance outwash are exposed beneath the Elmendorf Moraine and overlie the Bootlegger Cove clay. The outwash extends eastward at least to the Eagle River. It underlies the till in the bluff on the west side of Eagle River, $\mathrm{SW}_{1}^{1} / 4 \mathrm{SW}^{1} / 4$ sec. 9, T. $14 \mathrm{~N}$., R. 2 W., and overlies peat and preWisconsin gravel in the bluff just north of the Eagle River station, in the SW $1 / 4 \mathrm{SE} 1 / 4$ sec. 9. The total extent of the outwash in the area is not known, but the pebble and cobble gravel that underlie till and overlie the peat bed one-fourth mile east of Goose Bay on 
the west side of Knik Arm (Trainer, 1953, p. 10) probably correlates with the advance outwash.

In the bluff along the east side of Knik Arm, the Naptowne advance outwash consists either of current crossbedded stratified sand, pebbles, and cobbles that are truncated by other beds, or of nearly horizontally bedded layers with occasional cut and fill structures. Few beds are continuous for more than 200 feet. Sections of small channels are represented by catenary sand lenses within sorted beds of pebble gravel. The sand lenses locally display an inclined current bedding. Elsewhere along the Arm the outwash consists of horizontally bedded silt interlayered with coarse to medium sand. Less commonly the advance outwash is distorted and deformed by Recent slumps and earthflows.

North of the Eagle River Flats in the SE1/4 sec. 18, T. 15 N., R. 2 W., the advance outwash ranges in thickness from 4 to 25 feet. A cobble layer at the base of the outwash separates it from the underlying advance outwash of the Knik glaciation. This cobble layer can be traced, as can the cobble layer at the base of the Knik advance outwash, northeastward where it overlies the till of the Knik glaciation. The cobble layer is used to separate the Naptowne advance outwash from the Knik advance outwash. The Naptowne advance outwash is well stratified in this area, and in most exposures is a pebble to cobble gravel interbedded with medium sand in layers about 5 feet thick. Locally, the gravel is iron stained in 6to 18-inch layers.

Near the mouth of Sixmile Creek, the lower part of the advance outwash directly overlies the Bootlegger Cove clay and is cemented by iron oxide into massive layers of hard, compact conglomerate that extend for about 1 mile south of the creek. Seeps and springs along the upper surface of the Bootlegger Cove clay deposited iron oxides to cement the conglomerate. The conglomerate resists weathering and wave action but blocks of conglomerate over 5 feet in the longest dimension are separated from the layers and are common along the beach in this area.

The exposed thickness of the Naptowne advance outwash ranges from 5 feet to 30 feet along Knik Arm. Along the bluff on the west side of the Eagle River in sec. 9, T. 14 N., R. 2 W., 42 feet of outwash is exposed beneath the ground moraine. The lower part of the slope is covered by wash and slump, so that the total thickness of outwash is not known. The upper surface of the outwash is nearly horizontal in most exposures where the contact is exposed. As interpreted in this report, the advance outwash was deposited in front of an actively moving glacier. Thus the advance outwash was deposited by melt-water streams flowing in front of the Wis- 
consin glacier as it advanced to the position marked by the end moraine. The outwash was deposited over the Bootlegger Cove clay, and in turn was covered by the ground moraine deposited by the overriding glacier. Most of the advance outwash south of the end moraine apparently was removed by the streams that formed the outwash plain that parallels the south flank of the end moraine. Sand and gravel of the advance outwash that overlies the Bootlegger Cove clay, underlies the end moraine and extends under the Naptowne pitted outwash. Slump obscures its relationship to the outwash, but the advance outwash may underlie the Naptowne outwash in the vicinity of the Elmendorf Air Force Base.

\section{END MORAINE}

The sinuous ridge that crosses the northern part of the area, referred to hereafter as the Elmendorf Moraine, is mapped as an end moraine. The Elmendorf Moraine extends beyond the area mapped on both sides of Knik Arm toward the Matanuska Valley (pl. 2).

The Elmendorf Moraine ranges in width from $1 / 2$ to more than 1 mile. North of Anchorage and the Elmendorf Air Force Base runways, it crosses the area diagonally to the southwest, a distance of about 10 miles. It continues north along the mountains and west across Knik Arm from Cairn Point. It is bounded along most of its southern edge by outwash, and its northern edge by ground moraine, kame fields, kame terraces, and abandoned channels, all features of the Naptowne glaciation. Near the extreme eastern boundary of the area, the end moraine is cut by the Eagle River. Though the end moraine has a maximum altitude of over 450 feet in the NW $1 / 4 \mathrm{NW}^{1} / 4$ sec. 23, T. 14 N., R. 2 W., its maximum relief is in the SE1/4 SE $1 / 4$ sec. 32 , T. 14 N., R. 3 W., where it stands 100 feet above the Naptowne outwash. The surface of the moraine drops 250 feet below the outwash in a kettle trough north of the morainal rim that stands behind the Kermit Roosevelt Memorial Cemetery.

In most places the south slope of the Elmendorf Moraine is steep and the north slope is gentle, but locally the converse is true because the sharp crestline is not everywhere toward the southern edge of the moraine. The narrow linear crestline sweeps in a gentle S-curve from the south edge of the moraine in the $\mathrm{NE}_{1} / 4 \mathrm{NE} 1 / 4$ sec. $6, \mathrm{~T} .13$ N., R. 3 W., to the north edge of the moraine in the NW1/4 NW1/4 sec. 26 , T. 14 N., R. $3 \mathrm{~W}$. where the ridge gives way to an area of kames and kettles. East of this gap, the ridge continues as a discontinuous arc along the south edge of the moraine from the NE1/4 NE1/4 sec. 35, T. 14 N., R. 3 W., to Fossil Creek. Fossil Creek transects the moraine in a deep ravine.

$507199-60-5$ 
Most of the surface of the moraine is covered by kames and kettles. Many of the kettles contain ponds or lakes, others contain swamp deposits, and still others are unfilled. Small drainageways locally modify the knob and kettle topography. The till in the end moraine consists of round to subround pebbles, cobbles, and boulders in a tan or light-gray silt and clay matrix. Erratics 4 feet in the longest dimension are common. Although most of the pebbles and cobbles are dark gray, the overall color is light gray or tan, depending on the color of the matrix. In most exposures the till is compact, but in some exposures it is less compact in the upper few feet and may grade into a loose pebble or cobble rubble. The end moraine contains thick deposits of stratified drift as well as the unstratified till. Intratill fluvial sand and gravel, and the sand and gravel of ice-contact deposit compose part of the end moraine.

A cross section of the moraine is well exposed in the bluff near Cairn Point. Composed of sand and gravel in a silt matrix, the till is hard and compact but contains discontinuous lenses of somewhat distorted stratified sand and gravel. The till locally is crudely sorted.

The thickest observed section of the Elmendorf Moraine is near Cairn Point (measured section 4, p. 39) where an exposure from the Bootlegger Cove clay to the top of the morainal ridge shows 110 feet of till. About 4,000 feet to the east, the top of the morainal ridge is 100 feet higher in altitude than at the measured section, so it may be assumed that if the basal contact here lies on the Bootlegger Cove clay-although the Naptowne advance outwash may separate the two deposits-the maximum thickness of the moraine is about 200 feet.

The exposure of till, over the Bootlegger Cove clay and under the advance outwash, along Knik Arm in the SW1/4 sec. 29, T. $14 \mathrm{~N}$., R. $3 \mathrm{~W}$. suggests that a glacier of Wisconsin age preceded the Naptowne glacier, and extended beyond the end moraine deposits. The Elmendorf Moraine probably overlies the advance outwash (pl. 1) although such outwash, if present, was covered when the section at Cairn Point was measured (measured sec. 4, p. 39). Karlstrom (1957, p. 73) correlates the Naptowne glaciation in the Cook Inlet as representing all of Wisconsin time. He previously (1950) included what is here called the Elmendorf Moraine as part of the Naptowne morainal belt. The Elmendorf Moraine, however, may not represent the earliest advance of a Wisconsin glacier; a postKnik and pre-Naptowne glaciation may be recorded by the till at this locality. Such a suggested pre-Naptowne advance is further indicated by the drumlin in the NE1/4 NW1/4 sec. 12 , T. 13 N., R. 3 W.-mapped as ground moraine of the Knik glaciation-that over- 
lies a blue clay that may be the Bootlegger Cove clay. Ice-contact slopes in a pitted phase of the Naptowne outwash also support the conjecture of this advance. Whether this advance beyond the Elmendorf Moraine is a pre-Naptowne Wisconsin or is merely a fluctuation of the Naptowne glacier that deposited the end moraine is unclear. The Naptowne glacier advanced into the area from the north over outwash deposited in advance of the glacier. The glacier remained at the position marked by the Elmendorf Moraine long enough to deposit the moraine.

The deposits of the end moraine were derived from north of the: Anchorage area and carried in the lower part of, within, or on top of the Naptowne glacier as it advanced into the Anchorage area. Accumulating directly from the melting ice front as a heterogeneous mixture or from melt-water streams flowing from the glacier, debris carried by the glacier formed the ridges of the end moraine. Because the end moraine marks the position of farthest recorded advance of the Naptowne glacier, subsequent fluctuations did not obliterate the moraine.

GROUND MORAINE

The ground moraine is coextensive with the lowland north of the end moraine. Although the ground moraine underlies this area, later deposits of different origins locally blanket the moraine. Near the center of the lowland, the Eagle River has eroded the ground moraine and other deposits to form the Eagle River Flats, a silt-filled reentrant of the Arm. Along Knik Arm, northward from the Elmendorf Moraine, the ground moraine is almost continuously exposed. Exposures are infrequent elsewhere in the area covered by the ground moraine. The ground moraine forms steep bluffs along Knik Arm; slopes range from $25^{\circ}$ to $90^{\circ}$. Back from the Arm the surface is pitted with kettles. Many drumlins trend southwesterly parallel to groovelike depressions in the ground moraine. Locally, the drumlins are closely spaced and form an en echelon series of ridges. The ground moraine is an area of relative low relief that seldom exceeds 50 to 75 feet. The maximum altitude of about 300 feet in sec. 9, T. 14 N., R. 2 W., provides about 100 feet of relief.

Drainage in the ground moraine is not well integrated, although small streams occupy abandoned channels entrenched in the surface. Some of the streams, like Sixmile Creek and Clunie Creek, occupy channels as much as 125 feet deep. Most of the channels trend southwesterly and give the area a distinctive striated appearance that differs markedly from the appearance of Knik ground moraine south of Anchorage.

Most of the kettles throughout the area are shallow depressions that are unfilled in places, or contain lakes or swamps. They are not 
connected by streams, except in the abandoned channels where modern streams flow along previously established courses. The ground moraine is composed predominantly of tan to light-gray compact, stony till that contains rounded cobbles in a silt and clay matrix. In some exposures between the Eagle River and Sixmile Creek, the contact between the till and the underlying stratified sand and gravel of the advance outwash is distinct and clearly defined, but in other exposures it is obscure and appears to be gradational.

A less compact till and poorly sorted sand and gravel locally overlie compact till along Knik Arm. The contact between them is gradational in some exposures, distinct in others. Dampness is common in the more permeable looser materials locally, and springs flow in places along the contact between the looser materials and the compact till.

Naptowne till is discontinuous along the bluff of Knik Arm. Stratified sand and gravel, which extends to the top of the bluff, locally overlies the Bootlegger Cove clay. This relationship is true in the NE1/4 SE1/4 sec. 20, T. 14 N., R. 3 W., where the Bootlegger Cove clay is overlain by about 40 feet of sand and gravel. Some of this stratified sand and gravel is advance outwash deposited in front of the advancing Wisconsin glacier. Other deposits are later outwash related to the withdrawal of the glacier. One such deposit is the 12 feet of stratified sand and gravel overlying 40 feet of till that forms the point of land south of the Eagle River Flats in the SW1/4 SW $1 / 4$ sec. 2, T. 14 N., R. 3 W.

The ground moraine is exposed in two places along the Eagle River in sec. 9, T. 14 N., R. 2 W. On the west side of the river, in the SW1/4 sec. 9 , about 42 feet of compact cobble till that has a silt and clay matrix overlies about 100 feet of poorly bedded sand and gravel. In the SW1 $1 / 4 \mathrm{SE} 1 / 4$ sec. 9 , approximately 20 feet of silty till is exposed just below the grade of the Alaska Railroad. More than 25 feet of slump material covers the slope below the till, and about 6 feet of sand and gravel-outwash deposited in front of the advancing Wisconsin glacier-is exposed below the slump and overlies a peat deposit. In the NW1/4 sec. 17, T. 14 N., R. 2 W., about 12 to 15 feet of brown till containing sand and gravel layers is exposed along the river bluff and in road cuts.

Till is exposed in the south end of a drumlin in a 15-foot cut along a jeep road in the NE1/4NE1/4 sec. 5, T. 14 N., R. 2 W. The till is gray, composed of pebbles and cobbles in a silty to sandy matrix, is compact and has a platy. cleavage that more or less parallels the surface of the drumlin. The upper 2 to 3 . feet is crudely stratified, and may be ablation debris, a solifluction deposit, or slopewash. 
Till is not the only material at the surface east of Knik Arm. Stratified sand and gravel along small melt-water streams cover the till locally. Poorly sorted sand and gravel deposited in part during ablation of the ice, but without distortion of bedding, covers much of the moraine. The maximum thickness of this poorly sorted sand and gravel is not known, but as much as 15 feet of it is exposed in many cuts along the roads north of the Elmendorf Moraine.

The exposed thickness of the ground moraine ranges from about 6 feet to about 40 feet along Knik Arm and the Eagle River. If the lower contact surface of the ground moraine with the underlying deposits is generally horizontal, the hills and hummocks of the moraine east of the Arm may indicate a thickness as much as 100 feet.

After the Naptowne glacier was stationary long enough to deposit the end moraine, the ice lobe retreated leaving detached and isolated blocks of stagnant ice. The compact basal till in the ice was deposited over the advance outwash that accumulated in front of the advancing glacier. The drumlins probably formed from till lodged beneath the advancing ice. Superglacial till was laid down on top of the basal till locally, and streams flowing on the ice and on the ground moraine reworked some of the till into deposits of stratified sand and gravel.

Most of the kettles in the ground moraine are shallow rather than deep depressions. Many are in areas where sand and gravel overlie till; they were probably formed by the melting of buried ice rather than by deposition of material around blocks of ice projecting through the surface.

\section{KAME FIELD AND KAME TERRACE DEPOSITS}

Deposits of the kame fields and kame terraces, sequence 1, parallel the northern edge of the Elmendorf Moraine southwest from Fossil Creek to beyond Otter Lake. Sequence 1 ranges from about one-quarter mile to about six-tenths of a mile in width, and is about $31 / 2$ miles long. The kame fields are at the north and south ends of the kame terrace. Extending from north of Fossil Creek south to Otter Lake, the deposits of the kame fields and kame terrace, sequence 2, parallel the western edge of sequence 1 of the kame fields and kame terrace deposits but stand lower. The deposits of sequence 2 range from one-fourth mile to six-tenths of a mile in width and are about $21 / 2$ miles long.

The flat surface of the kame terrace, sequence 1, gives way upstream and downstream into knob and kettle topography in the kame fields. A continuation of the grade of the kame terrace not 
only approximates the altitude of the tops of the kames in the kame field at the north end of the terrace, but projects to the upper remnant of the channel of the ancient Fossil Creek. A scarp separates this kame field and terrace sequence from topographically lower kame field of sequence 2. As in sequence 1, the flat surface of the kame terrace, sequence 2, gives way both upstream and downstream into the knob and kettle topography of the kame fields. The kames and kettles, however, are not as well developed in this sequence as in sequence 1. The surface of the kame terrace slopes southward into the swamp and abandoned channel around Otter Lake. Extending the surface of the kame terrace and kame fields northward, the surface projects into the terrace surface of the abandoned channel mapped along the Eagle River. Ice-contact deposits related to the Naptowne glacier were deposited by streams flowing on or adjacent to the ice. Typically, the deposits are sorted and stratified but show abrupt changes of grain sizes between adjacent layers, have extremes of grain sizes interbedded in the same stratified layer, show local deformation of layers, and contain blocks of till. Two cycles or "sequences" of alluviation are suggested by the levels of surfaces that extend south from Fossil Creek beyond Otter Lake. The first cycle of alluviation resulted in a kame terrace $\left(Q / c t_{1}\right)$, which gave way into kame fields $\left(Q k_{1}\right)$ at both ends, and the second cycle of alluviation resulted in a kame terrace $\left(Q K t_{2}\right)$ that also gave way into kame fields $\left(Q k_{2}\right)$.

In the SW1/4 sec. 19, T. 14 N., R. 2 W., a gravel pit in the kame terrace, sequence 1 , displays layers of fluvial bedded sand. The upper 18 inches of the kame terrace is oxidized. Pebble and cobble gravel, locally with collapsed bedding, overlies the sand. Layers of gravel parallel the edges of included blocks of silt. Blocks of till are exposed in the lower part of the pit. A cut through the kame field, sequence 2, along the road in the SW1/4 sec. 17, T. 14 N., R. 2 W., shows a silty cobble and boulder gravel that locally has collapse structure.

While the melt water flowing along the south side of the Eagle River valley cut a trench into the outwash and moraine at Fossil Creek, ice still lay along the north side of the end moraine. Diverted by the ice barrier, the waters from Fossil Creek flowed between the ice and the moraine and deposited the kame terrace, sequence 1, that extends west from Fossil Creek beyond Otter Lake. Subsequent melting of the ice left the kame terrace and the kame fields. Some of the kettles probably formed from blocks of ice that projected through the surface, whereas others probably formed when buried blocks of ice melted and the overlying deposits collapsed.

Melt-water streams that flowed from the active ice front to the north through channels in the ground moraine and from the north- 
east in channels along the flank of the mountains converged and formed the wide melt-water channel now occupied by the modern Eagle River. This channel extends southwest past the Eagle River Flats to form the valley of Sixmile Creek. When it was cut, the channel of sequence 1 was abandoned. The overflow from the Eagle River valley may have continued to flow in the channel of Fossil Creek, and may have joined the waters flowing in the new channel of Sixmile Creek. The kame fields and kame terrace of sequence 2 were deposited in this drainage. Stagnant blocks of ice that formed part of one wall probably were buried under the terrace in places and left ice-contact slopes as the west scarp of the sequence 2 kame field and kame terrace on the eastern shore of Otter Lake.

\section{PITTED OUTWABH}

Stratified sand and pebble gravel with a surface that slopes southeast from the front of the Elmendorf Moraine is mapped as pitted outwash. It covers parts of secs. 5, 6, and 7, T. 13 N., R. $3 \mathrm{~W}$. It extends from the south edge of the Elmendorf Moraine along Knik Arm for about 1 mile, and it ranges in width from two-tenths of a mile to about three-fourths of a mile. The western and eastern boundaries of the outwash are erosional contacts. The pitted outwash apparently overlies the Bootlegger Cove clay in front of the Elmendorf Moraine. The advance outwash underlies the moraine in the bluff but its relationship to deposits in front of the moraine is obscured by slump. Possibly the lower part of the pitted outwash merges with the advance outwash.

The pitted outwash is bounded on the west by the bluff along Knik Arm, where slump blocks form a hummocky landslide area. The surface of the outwash slopes southeast from the front of the Elmendorf Moraine. The largest kettle in the pitted outwash is about 400 feet wide, at the widest place, about 2,000 feet long, and about 30 feet deep. These dimensions are estimated, as the original landform has been modified by earthmoving equipment. Several short incised channels cut through a scarp that bounds the pitted outwash on the south.

The pitted outwash lacks uniformity in particle size and stratification. Where it overlies the Bootlegger Cove clay in the landslide area along Knik Arm, the pitted outwash is composed of gray fine to medium sand. Fine sand overlies the Bootlegger Cove clay near the Loop Road in the SE1/4 SE1/4 sec. 6, T. 13 N., R. 3 W. A pit adjacent to the east side of the large kettle near the west end of the east-west runway in Elmendorf Air Force Base, displays festoon crossbedding that indicates deposition from the north before collapse due to melting ice. Fifteen feet of coarse sand containing 
layers of medium sand are exposed in the pit. Brown silt layers one-half to 6 inches thick are interbedded with gray sand. Coal fragments are scattered throughout the sand; pebbles are commonly in layers; a few cobbles are intermixed with the pebbles.

The maximum exposed thickness is near the Loop Road in the $\mathrm{SE} 1 / 4 \mathrm{SE} 1 / 4$ sec. 6, T. 13 N., R. 3 W., where approximately 20 feet of fine sand overlies the Bootlegger Cove clay. The thickness of the pitted outwash along Knik Arm is obscured by the many slump blocks and by slopewash. It is the authors opinion that the pitted outwash thickens toward the end moraine.

Contorted beds of silt, sand, and pebble and cobble gravel are exposed in a ditch about 750 feet west of the east-west runway and about 300 to 500 feet north of the edge of the runway. Along this ditch a fine sand that contains layers and lenses of small pebbles is overlain by a clayey silt layer about 18 inches thick. The dips of the sand layers are variable and range from about $30^{\circ}$ to nearly vertical depending on the amount of distortion of the beds. In places the sand contains distorted layers of silt.

Pebble gravel overlies the sand and silt layers and truncates the steeper dipping sand beds in most places along the ditch. Small vertical faults in the sand and silt have displacements of 18 inches to 3 feet. The pebble gravel is faulted down into the sand and silt in some places, but the displacement in the gravel is obscure. The gravel is drawn into the silt and sand in bulbous fingerlike involutions (pl. $8 B$ ). Stratification of the gravel tends to parallel the walls of the enclosing silt to the extent that in circular involutions the distorted gravel shows concentric arrangements.

The involutions in the silt, sand, and pebble gravel in the ditch exposure can be explained by several processes: (1) they may have resulted from deformation owing to the weight of the gravel overlying saturated silt and sand whereby the sand and gravel settled into the silt as stringers and fingers; (2) overriding of the sediments by ice may have compressed, sheared, and faulted the deposits and contorted the bedding; (3) ice-shove may have contorted the sediments in front of an advancing glacier; (4) melting of buried ice blocks may have collapsed the sediments and may have promoted flowing that contorted the beds; and (5) frost action may have formed involutions and other contortions in the sediments.

The sediments are considered part of outwash deposition, and do not suggest saturation that would allow penecontemporaneous deformation (Shrock, 1948, p. 156). For that reason, possibility (1) is not considered a major cause of deformation. Because the involuted deposits are in front of the end moraine and were not overridden by ice, possibilities (2) and (3) can be discounted. Either 


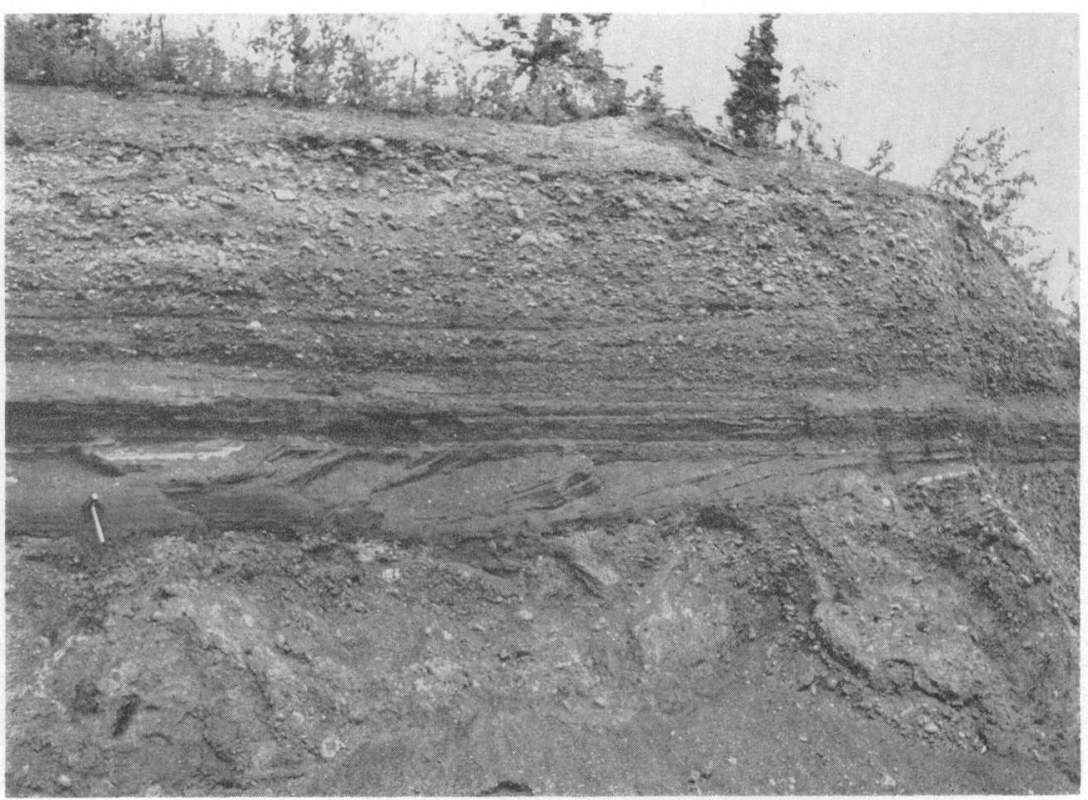

A. Abandoned-channel deposits overlying pebbly till of ground moraine (Knik in age) on southwest side of Seward to Anchorage Highway at mouth of Rabbit Creek.

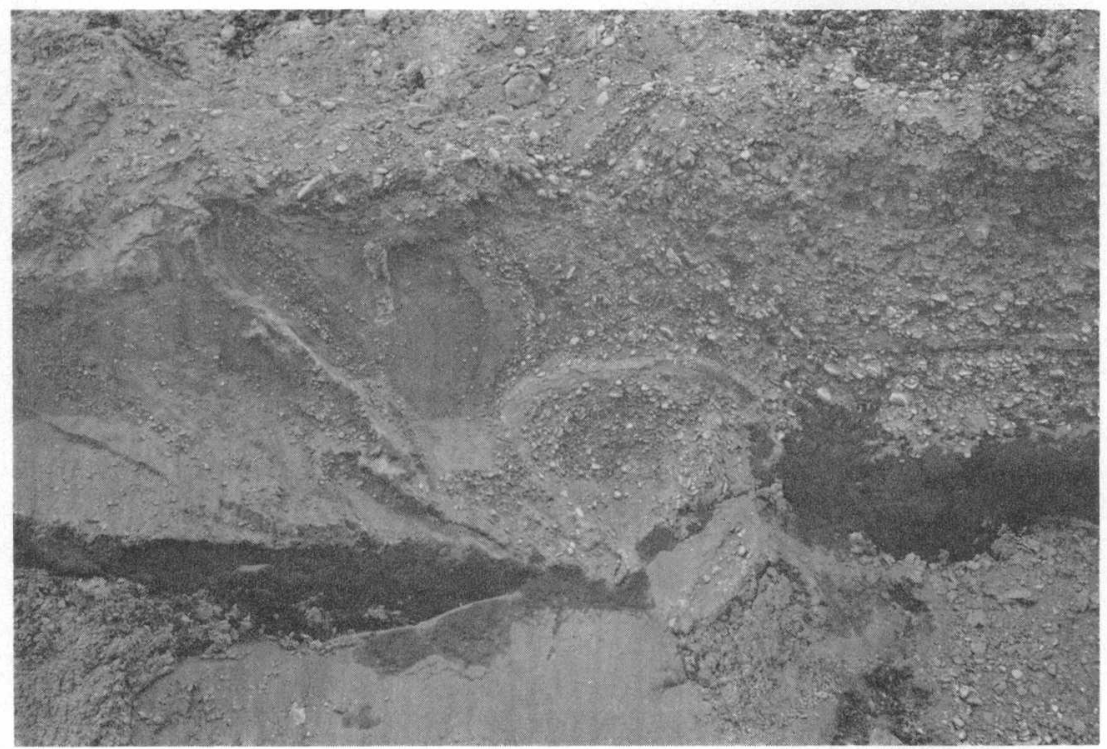

B. Involutions in pitted outwash of Naptowne age along drainage ditch in NW1/4 sec. 5 , T. 13 N., R. 3 W., about 500 feet north of east-west runway, Elmendorf Air Force Base. U.S. Army photograph. 


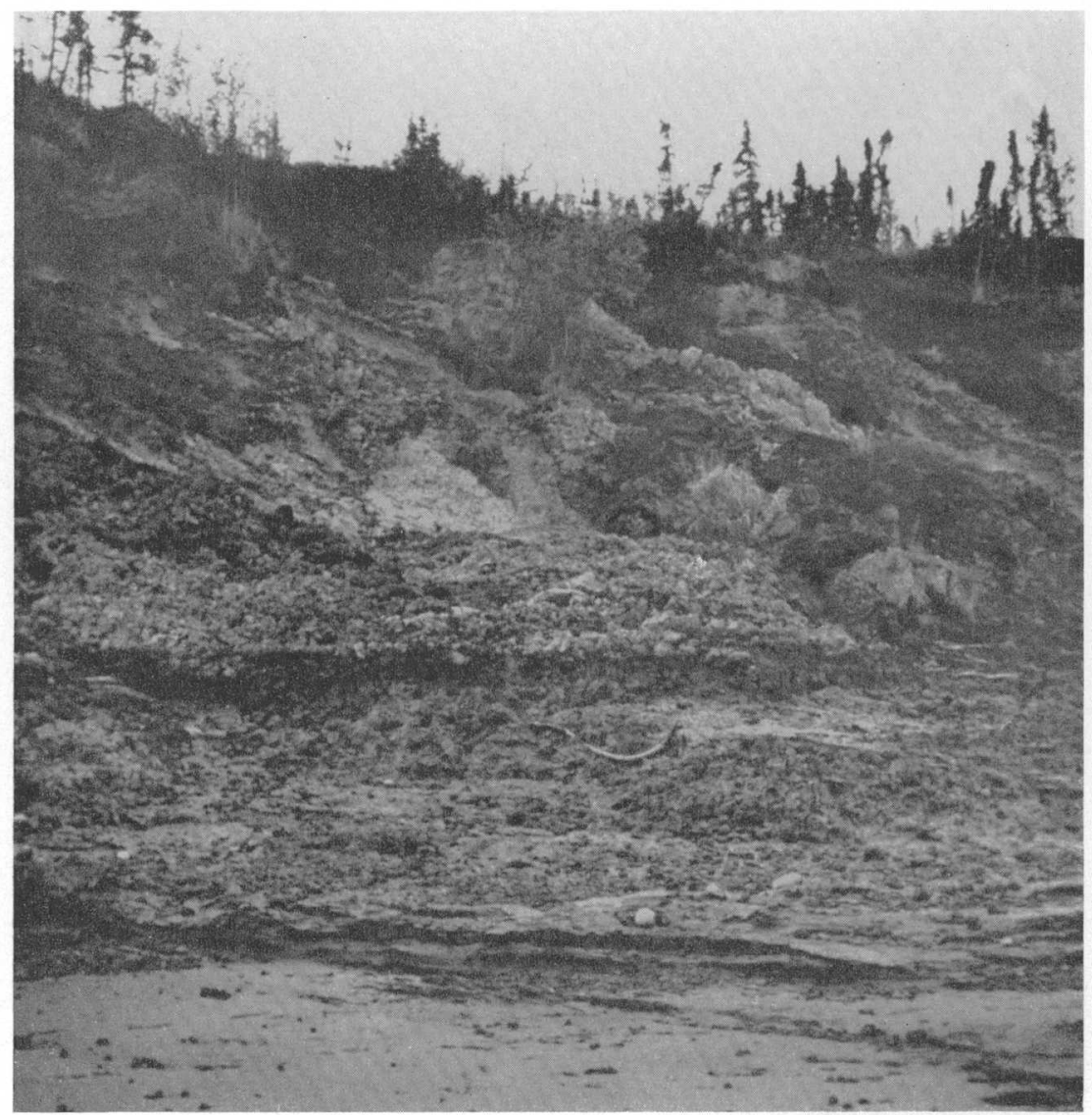

Slides and flows in Bootlegger Cove clay along Knik Arm southwest of Anchorage, Alaska, in the SE1/4 sec. 21, T. 13 N., R. 4 W. 
possibility (4) or (5) could individually cause the displacement and involutions exposed along the ditch, but a combination of them, probably not contemporaneous in occurrence, are believed to have caused these features. The small faults, slumps, and displacements in the sand and gravel likely resulted from collapse of the sediments when buried blocks of ice melted. Frost action would most likely destroy any fault trace. Because the collapse features are in the upper part of the exposure they would indicate frozen ground at depth. It may be inferred that the collapse and faulting are later features than those caused by the frost action.

Involutions caused by frost action have been described by Denny (1936), Sharp (1942), Shrock (1948), and Schafer (1949). An assumption that the involutions are freeze and thaw features would require frozen ground near the surface, perhaps within 15 feet of the surface (Sharp, 1942, p. 128), in order to form a barrier that would force water to saturate the upper parts. Schafer $(1949, \mathrm{p}$. 163) quotes Zuener (1945, p. 12) as stating that involutions form only on perennially frozen ground.

Streams flowing to the southeast from the end moraine west of Cairn Point, as suggested by the slope of the surface of the outwash, and confirmed by the east and southeast dip of the beds, deposited the outwash and buried blocks of ice in front of the glacier. The outwash subsequently collapsed where the ice blocks melted, and surface was pitted.

\section{OUTWASH}

The flat surface that adjoins the Elmendorf Moraine on the south, is an outwash plain related to the Naptowne glaciation. It extends about $121 / 2$ miles southwest from the eastern boundary of the project south of the Elmendorf Moraine. It ranges in an undissected width from about one-quarter of a mile north of Hood and Spenard Lakes to about 2 miles in width near the Elmendorf Air Force Base. At its widest point it is about $41 / 2$ miles wide. It underlies parts of the Elmendorf Air Force Base, Fort Richardson, and most of Anchorage.

The surface of the outwash plain slopes southwest about 32 feet per mile. The even continuity of the plain is locally disrupted by ridges and drumlins of ground moraine of the Knik glaciation that project through the outwash, by Wisconsin deposits that overlie the outwash, and by erosion of the outwash. Although stream channels are entrenched into the outwash, the overall level surface of the outwash continues without any pronounced break in slope until it disappears beneath the swamp deposits around Lake Spenard, Lake O'Connell, as well as east of Bonibrook. Kettles pit the generally even surface of the outwash near Lake Spenard. Steep ice-contact slopes bound the kettles, some of which are partly filled 
with peat and muskeg. The pitted surface grades into the unpitted outwash surface and also extends gradually under the peat of the swamps that bound Connors Lake and Lake Spenard.

The outwash grades northeastward from stratified fine sand along the bluff near Turnagain Heights into coarse sand, cobbles, and boulders toward the Eagle River. Lenses of alluvial coal range in thickness from 2 to 6 inches and in length from 3 to 15 feet; individual fragments are as large as 4 inches in diameter. Lenses of detrital coal have been interpreted erroneously as coal seams where exposed in excavations or recorded in wells.

Toward the Eagle River valley (off the map) and near Fossil Creek the outwash contains many boulders more than a foot in diameter. The surface of the outwash is in fact almost a boulder pavement, but contains negligible amounts of pebbles and less sand than toward Knik Arm. In this area, where the outwash is coarse, weak Tertiary sandstone constitutes part of the smaller fraction. Beneath Anchorage, pebble gravel in lenses 2 to 6 inches thick and 20 to 50 feet long alternates with lenses of coarse sand. This contrasts with the grain size of the deposit southwest of Anchorage toward Knik Arm where pebble gravel is almost absent. A few exposures in the pitted area around Lake Spenard show a fluvial bedding in fine- to medium-gray sand. This sand compares in grain size to the sand of the younger outwash exposed along the bluffs of the Knik Arm near Turnagain Heights, and along the banks of Fish and Chester Creeks. Along the north side of the road to Radio Station KFQD 35 feet of partly crossbedded gray sand overlies the Bootlegger Cove clay in the SW1/4 SW1/4 sec. $24, \mathrm{~T} .13 \mathrm{~N}$., R. $4 \mathrm{~W}$. The sand contains about 1 percent of pebbles larger than 1 inch in diameter, about 5 to 10 percent of pebbles larger than $1 / 2$ inch in diameter, and about 50 percent fine sand. In the bluff along Knik Arm, in the middle of sec. 23 , T. 13 N., R. 4 W., about 75 percent of the outwash is crossbedded fine to very fine sand that contains about 1 percent of pebbles larger than 1 inch in diameter.

Southwest of Anchorage along Knik Arm about 400 feet west of the east section line into sec. 21 , T. 13 N., R. 4 W., 12 feet of outwash overlies the Bootlegger Cove clay. The lower 8 feet of the outwash is a gray medium sand and the upper 4 feet is a gray silt to silty sand. A peat layer about 6 inches thick extends laterally about 12 to 18 inches from the top of the outwash. Eight feet of peat overlies the outwash to the surface. The 6-inch peat layer was sampled and a carbon-14 determination dated the peat at 11,600 \pm 300 radiocarbon years (Rubin, Meyer, U.S. Geological Survey, written communication, April 2, 1957, W-540). Considered a part of the last phase deposition of the Naptowne outwash the peat layer places a minimum age on the deposition of the outwash. 
Some of the ranges of exposed thicknesses along Knik Arm are, 5 feet in the NW1/4 SW1/4 sec. 23, T. 13 N., R 4 W., 30 feet between Fish Creek and Chester Creek, and over 10 feet in the bluff above the Alaska Railroad in sec. 13, T. 13 N., R. 4 W. The deposit thickens away from Knik Arm, so that where the road to Radio Station KFQD crosses Fish Creek, sand 35 feet thick overlies the Bootlegger Cove clay. The outwash ranges in thickness from 20 to 40 feet in secs. 16 and 21 , T. 13 N., R 3 W. In the SE1/4 sec. 8, T. $13 \mathrm{~N}$., $\mathrm{R} 3 \mathrm{~W}$, , over 50 feet of outwash is exposed in the bluff along Ship Creek.

Well-log records (Cederstrom and Trainer, 1953; U.S. Corps of Engineers, unpublished well records) indicate that the outwash is about 60 feet thick in most places under Fort Richardson and the Elmendorf Air Force Base, but the thickness is not everywhere constant. Cederstrom (1952, p. 21) considers the outwash deposits to be as much as 300 feet thick and more than 100 feet below sea level near Anchorage, but he included the Bootlegger Cove clay as part of the outwash. In a pit in the NW1/4 sec. 34 T. 14 N., R. 3 W., 91 feet of gravel is exposed against a till hill, 68 feet of which extends above the outwash surface. Part of the thickness here, however, could be caused by small fans deposited by later streams flowing from the end moraine. Channels cut in the surface of the Bootlegger Cove clay, as along Chester Creek, increase the thickness of the outwash. The outwash under Anchorage is shown on plate 5 .

An outwash plain that extends out of the area mapped and up the Eagle River valley for several miles (Dobrovolny and Miller, 1950, Knik quadrangle map) is considered by the authors to be a continuation of the younger outwash. Reconnaissance up the Eagle River valley indicates that the source of the outwash was a glacier in the Eagle River valley.

The Naptowne glacier and related morainal deposits dammed the mouth of the Eagle River valley. The Eagle River glacier had a small supply area, and retreated up its mountain valley leaving a gap between it and the morainal dam. Melt water accumulated as a lake behind this morainal barrier. Acting as a settling basin, the lake was completely filled by clay and outwash deposits of sand, pebbles, and cobbles. The clear water overflowing from the lake probably cut some of the channels into the Bootlegger Cove claythough water from Ship Creek probably helped erode the clay (see pl. 5, near Spenard Road along Chester Creek) -as well as channels in the till and bedrock along the south flank of the Eagle River valley (Dobrovolny and Miller, 1950). The outwash started to deposit from the overflow waters and covered the area in front of the Elmendorf Moraine and filled the depressions between hills of ground moraine of the Knik glaciation. The outwash channel 


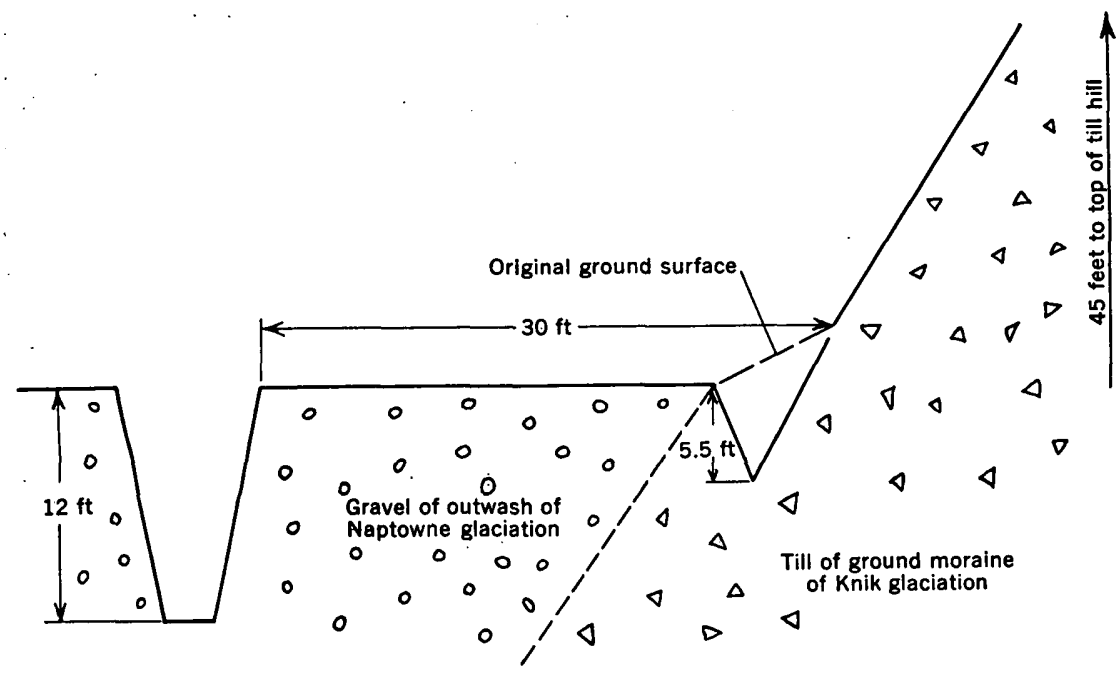

FraURE 5.-Relationship of outwash of Naptowne age to till of ground moraine of Knik age in SW $1 / 4 \mathrm{SE} 1 / 4$ sec. 31, T. 14 N., R. 2 W., as exposed in excavation.

in sec. 4 , T. 13 N., R. 2 W. originally was continuous with the channel in sec. 13, T. 13 N., R. 3 W. Ship Creek occupied the channel when it built an alluvial fan across the outwash deposits. Excavations in the $\mathrm{SW} 1 / 4 \mathrm{SE} 1 / 4$ sec. 31 , T. 14 N., R. 2 W. (fig. 5) showed outwash overlapping ground moraine on flank of a till hill. Seeking a shorter route to Knik Arm, the Eagle River flowed in a westerly direction as soon as the ice retreated far enough north of the Elmendorf Moraine. The channel of Fossil Creek, eroded into the outwash and the Elmendorf Moraine, probably is the shortened course of the Eagle River. Restriction and channeling of flow from the Eagle River along the shortened courses stopped deposition of the outwash.

The outwash from the Eagle River covered blocks of stagnant ice in the lowland isolated after retreat by the Naptowne glacier to the position marked by the end moraine from an advance or fluctuation. Such a block of ice apparently formed the depression containing Lake Otis. Many such stagnant blocks remained in the area around Lake Spenard and left kettles after they melted.

\section{ABANDONED-CHANNEL DEPOSITS}

Broad channels topographically higher than the Eagle River are incised into the ground moraine and Elmendorf Moraine, and the deposits that cover their level floors are mapped as abandonedchannel deposits. These deposits are restricted mostly to the ground moraine north of the Elmendorf Moraine, but a short channel is incised into the Elmendorf Moraine north of Whitney. In addition, 
the large abandoned channels at Fossil Creek and at the Eagle River station of the Alaska Railroad transect the end moraine.

Eagle River, Sixmile Creek, and Clunie Creek, all flow as consequence streams in wide abandoned melt-water channels that originate in the ground moraine. Sixmile Creek and Clunie Creek, as well as other streams that flow in channels starting abruptly in the ground moraine, extend to Knik Arm or the Eagle River Flats where the channels are truncated by the bluffs.

South of the Elmendorf Moraine, abandoned-channel deposits are mapped along Ship Creek, Chester Creek, the South Fork of Campbell Creek, Campbell Creek, Rabbit Creek, Potter Creek, the unnamed creek between Potter and Little Rabbit Creeks, and Rainbow Creek. Abandoned-channel deposits along the North Fork of Campbell Creek are not mappable at the scale of the map.

The surfaces of the stratified deposits covering the floors of the channels are graded and level. The channels range in width from about 180 feet in the smaller tributary channels to about 1 mile along the larger channels. These deposits are striking in appearance, as viewed through a stereoscope, where the channels pass through the lateral moraine. The bottom of the channel appears as a broad terrace that cuts through the hill topography. Most of the channels north of the Elmendorf Moraine end abruptly as hanging valleys in scarps along the sea cliffs or along the Eagle River.

The abandoned-channel deposits extend from the mouth of Ship Creek more than 6 miles upstream where they grade into the alluvial fan. The flat surfaces of the abandoned-channel deposits south of Ship Creek slope southwest about 36 . feet a mile to Chester Creek. The northward contact with the alluvial fan is gradational; no prominent scarps separate the two deposits. The channels range in width from about two-tenths to about four-tenths of a mile.

In most places in the ground moraine area, the deposits in the abandoned channels consist of cobble gravel and boulders with thin but widespread lenses of sand and pebble gravel. The dominant particle size varies from place to place depending on the local composition of the materials from which the deposits were derived. Most of the abandoned-channel deposits are veneers only 4 to 12 feet thick. At the mouth of Sixmile Creek, 10 feet of abandoned-channel sand overlies about 30 feet of coarser advance outwash. Channel surfaces are covered locally by a veneer of silt which in places makes the land useable for agriculture.

South of the Elmendorf Moraine abandoned channels were eroded into the Naptowne outwash. The abandoned-channel deposits here are generally coarser than the enclosing outwash inasmuch as the waters scoured and reworked the outwash leaving only the coarser 
material. Additional coarse material was brought in from the outwash upstream. Abandoned-channel deposits along Ship Creek are composed of stratified coarse sand and pebble gravel that contains some cobbles. In the $\mathrm{NW} 1 / 4 \mathrm{SW} 1 / 4$ sec. 9 , T. $13 \mathrm{~N}$., R. $3 \mathrm{~W}$., the deposit ranges in thickness from 11 feet at the edge of the valley to about 35 feet near Ship Creek about 800 feet away. Medium to coarse sand with pebbles constitutes the abandoned-channel deposit along Chester Creek and veneers the Bootlegger Cove clay where the Seward to Anchorage Highway crosses Chester Creek. The channel deposit is a thin veneer overlapped at the east end by swamp deposits. Along the South Fork of Campbell Creek east of the Campbell Airstrip the abandoned-channel deposits are 12 feet thick, and overlie till of the lateral moraine of the Knik glaciation. Along Campbell Creek, however, the abandoned-channel deposits are mostly composed of fine to medium sand and silt.

Cuts along the Seward to Anchorage Highway through the abandoned-channel deposits at the lower end of the stream between Potter and Little Rabbit Creek expose more than 11 feet of brown pebble to cobble gravel.

The length and parallelism of the channels north of the Elmendorf Moraine suggest that wasting ice north of the mapped area supplied vast amounts of melt water. The channels may have formed, however, as lateral drains during melting of the ice at the margin of the Naptowne glacier. That stagnant ice was in the area mapped is indicated by abrupt ice-contactlike slopes at the beginnings of some of the channels. The deposits of the abandoned channels are related, therefore, to the melt-water streams that flowed in part on the ice and in part on the ground moraine. The streams scoured their channels into the ground moraine.

Abandoned channels that are tributary to the Eagle River were cut by melt water from the Eagle River valley. They represent courses of the ancestral Eagle River. The surfaces of the abandonedchannel deposits along the Eagle River and Fossil Creek correspond in overall altitude with the surfaces of the deposits of the kame fields and kame terraces. Such similar levels implies the coincident deposition of the abandoned-channel deposits with the kame fields and kame terraces.

Along the mountain front south of the Elmendorf Moraine, other abandoned channels were also scoured by melt waters from the valley glaciers. The abandoned-channel deposits of Ship Creek, South Fork of Campbell Creek, and of North Fork of Campbell Creek (not mapped), merge into alluvial-fan deposits. The channels have been incised into all low-lying glacial deposits in the mountain valleys. 
Ship Creek, which carried an increased volume of water during deglaciation, is the probable source of water that eroded the channels in the Naptowne outwash. The water dropped most of its load and formed an alluvial fan, so that the water that flowed over the outwash carried little load and channels were incised into the outwash surface. During the increased flow, Ship Creek probably flowed westward and southwestward along the channels of the modern Chester and Ship Creeks. As the volume of water decreased, the flow was concentrated along what is now Ship Creek. The steeper gradients of the channel deposits along Chester and Ship Creeks suggests that erosion widened an existing Knik Arm thereby shortening the stream courses and steepening the gradients, or reduction of the load carried by the waters permitted entrenchment of the channels into the outwash, or a channel of the combined MatanuskaKnik River entrenched into the outwash and lowered the base level of the Ship Creek waters flowing along what is now Chester and Ship Creeks. In addition, isostatic adjustment, as the glaciers melted, may have raised the surface of the land and rejuvenated stream erosion. The authors favor a combination of conditions, cutting caused by a decreased load, and a lowered base-level control caused by entrenchment of the combined Matanuska-Knik River into the outwash west of Anchorage.

\section{SIIT}

A silt deposit underlies the International Airport, extends south of the A.C.S. road, and extends to the Alaska Communication Station. It covers part of secs. 32, 33, 34, T. 13 N., R. 4 W., secs. 3 and 4 , T. 14 N., R. 4 W., and imperceptibly grades into the surrounding deposits in these and other sections. Light tan to gray, the silt is even grained, horizontally laminated, and interlayered with thin sand stringers. Pebbles one-fourth to one inch in diameter are scattered throughout the silt. About 300 yards north of the A.C.S. road, along the road that passes west of DeLong Lake, the silt is even more sandy. A road cut in the silt shows distorted layers and bands of silt with sand. The silt is well exposed in the SE1/4NW1/4 sec. 3, T. 12 N., R. 4 W., where the A.C.S. road cuts through a ridge.

The exposed thickness of the silt is more than 6 feet. A well at the National Guard Air Station penetrated 13 feet of silt and the well at the Alaska Communication Station (Corps of Engineers, unpublished well logs, Point Campbell A.C.S. Receiver Station well, International Airport, National Guard facilities water well) penetrated about 30 feet of sandy silt and silt. No thickness of silt in the International Airport area greater than 17 feet is known to the authors. The silt appears to mantle older glacial deposits. 
Topographic relief within the silt area is about 40 feet near DeLong Lake. Irregular hills and kettles extend beyond the boundary of the silt.

The silt is considered to be a deposit of the Naptowne glaciation. Well records (Corps of Engineers, unpublished well records, International Airport, National Guard facilities water well; Cederstrom and Trainer, 1953, Nos. 86, 90) show that it overlies the Bootlegger Cove clay. Otherwise, the relationship of the silt to the adjacent deposits is not known, but two possibilities exist regarding its origin. The first possibility is that the silt represents a lacustrine deposit that may be part of the cycle of deposition of the Bootlegger Cove clay or a later lake episode. Laminations, pebbles, and sand stringers suggest such a lacustrine depositional environment. If the deposit is lacustrine, it is probably part of the Knik glacial sequence instead of the Naptowne glacial sequence, and was deposited in the same basin as the Bootlegger Cove clay.

The second possibility is that the silt is a relatively thin loess blanket over preexisting topography. Seventeen feet of the silt around the International Airport as compared to 30 feet at the Alaska Communication Station on the border of the delta, seems to the authors to be the reverse of what would be expected of a lake deposit; the Alaska Communication Station is near the edge of the deposits of the silt and the silt should be thinner.

Laminations in loess can be explained by slopewash action or stratification in puddles, perhaps during relatively quiet periods of deposition. The sand stringers, likewise, can be explained as part of slopewash or small stream accumulations. Stratification and sand stringers have been seen in loess in bluffs along the Missouri and elsewhere. Pebbles in loess have been observed in the central Great Plains. It is possible that the pebbles in the silt were blown in from a short distance, or were carried in by sheet wash or slopewash from upslope exposures of the sand and gravel that were either not as yet covered by silt or that temporarily were reexposed by wind action. The considerable area of Naptowne outwash is an ample source for the silt; winds blowing across the outwash may have picked up the finer fraction.

The many kettles in the silt can be explained under either hypothesis. If the silt accumulated in standing water, the deposit was probably evenly bedded and of relatively constant thickness, assuming deposition on a level surface. The kettles may have resulted from thawing of perennially frozen ground, or the silt may have been deposited as a loess blanket on an existing knob and kettle topography. Limited field evidence suggests that the silt is a loess mantle over pitted outwash, prodelta and delta deposits. 


\section{PLEISTOCENE OR RECENT DEPOSITS}

Two of the glacial deposits-morainal deposits, undifferentiated and glacial drift, undifferentiated-can not be restricted to either the Knik or the Naptowne glaciations, but they are glacial deposits that may range from early Pleistocene to Recent in age. Additional deposits that could be either Pleistocene or Recent in age are the alluvial-fan deposits. Deposition of the units could have started in the Pleistocene epoch and continued through the Recent epoch.

\section{MORAINAL DEPOSITS, UNDIFFERENTIATED}

Ridges and hills that are interpreted as moraines, but for which the age or depositional relationship to other deposits is not known, are mapped as morainal deposits, undifferentiated. These deposits were delineated by photogeologic methods and were checked in the field.

Moraines in the mountain valleys at a higher altitude than the lateral moraine are mapped near the mouth of Ship Creek valley along McHugh Creek, across Potter Creek, near the heads of Little Rabbit and Rabbit Creeks, along the South Fork of Campbell Creek, along an unnamed tributary to the South Fork of Campbell Creek, and along the tributary valley north of Campbell Creek Canyon (pl. 1). Smaller moraines in the valleys and cirques have not been mapped. The valley moraines typically form arcuate ridges across mountain valleys; the slopes of the moraines are more gentle downvalley than upvalley. A series of parallel north-south ridges, extend eastward from the mouth of Ship Creek valley. Stream erosion cut steepsided modern valleys through the moraines.

The materials in these undifferentiated morainal deposits were examined only along the Ski Bowl Road where over 40 feet of brownish oxidized(?) till overlies stratified tan lake silt in the NE1/4 sec. 9 , T. 13 N., R. 2 W. The lake silt may be the source of the brown color of the till. Elsewhere they should be similar physically to those in the lateral morainal and end moraine such as pebbles, cobbles, and boulders. Stratification from reworking of the till by melt water, though present, will be scarce. Valley moraines were derived from valley glaciers. Debris carried by the glacier was deposited at the fronts of the glaciers either at the maximum advances or at stillstands during glacial retreats. The moraine across Ship. Creek probably represents the Naptowne Ship Creek glaciers. Because the parallel ridges blocking the valley were examined only in reconnaissance, their relationship to the other deposits can only be surmised. The other moraines are probably late Wisconsin or Recent in age.

$507199-60-6$ 


\section{GLACIAL DRIFT, UNDIFFERENTIATED}

All of the glacial deposits east of the lateral moraine that do not have morainal topography are grouped into one map unit, glacial drift, undifferentiated. The slopes of the mountains are covered with glacial drift from about 1,500 feet altitude to 2,000 feet, though the upper boundary of the drift is not well defined. The drift extends along the sides of the mountain valleys up to altitudes of 2,000 or 2,500 feet and higher beyond the map boundary. The glacial drift that filled the valleys, slopes toward the lateral or undifferentiated moraines along the front of the mountains.

The glacial-drift deposits were examined only briefly in the field. The drift on the mountain slope along the road that parallels Little Rabbit Creek is a bouldery till, which suggests that the drift along the whole mountain front may be similar. The drift that fills the valley bottoms may be partly till and partly outwash composed of stratified sand and pebble and cobble gravel, and locally may be pond deposits of silt and peat.

Several of the bedrock spurs between valleys show smooth surfaces caused by overriding glacial ice, perhaps of the Caribou Hills glaciation of Kansan age. Some of these spurs, such as the spur that separates the South Fork of Campbell Creek from Rabbit Creek, have thin deposits of unmapped glacial drift. The thickness of the drift is not known but must be extremely variable.

Though the ages of the drift along the mountain front is not known, the deposits could represent several glacial ages; for example, Caribou Hills glaciation upward through Recent glaciations. The drift in the valleys probably is no older than the moraines (Wisconsin?) in the lower parts of the mountain valleys, but may be older than the early Recent moraines toward the heads of the valleys or the late Recent moraines in the cirques. The stratified or unstratified drift probably was derived from the valley glaciers or by possibly one or more of the pre-Wisconsin ice sheets.

\section{ALLUVIALFAN DEPOSITS}

Some of the alluvial-fan deposits grade upstream into deposits of the Naptowne abandoned channels. The ages of some of the alluvial fans are not known, because of obscured relationship of the fans to other units, and are grouped as one unit on the map. The largest alluvial fans are at the foot of the mountains where Ship Creek and the South Fork of Campbell Creek enter the lowland. Other conspicuous fan deposits are at the mouths of the mountain valleys of the North Fork of Campbell Creek, Rabbit Creek; and Little Rabbit Creek. One alluvial fan is mapped along the southern slope of the end moraine. Smaller alluvial fans are north of the 
Elmendorf Moraine at the mouths of Clunie Creek and Sixmile Creek, and along the north side of Chester Creek in Anchorage. Many small alluvial fans at the mouths of small streams are not mappable at the scale of the map that accompanies this report. Undissected alluvial fans in the area have a characteristic deltoid shape, a smooth upper surface, and an upslope apex. Although the streams that flow across the larger fans are well entrenched, most of the streams that flow across the smaller fans are but slightly entrenched. Most of the fan deposits grade almost imperceptibly into the materials along their perimeter.

As is typical of most alluvial deposits, the materials in the alluvial fans vary in size from place to place and in composition from sand to pebbles, cobbles, and boulders. The bedding may be irregular, continuous or truncated, horizontal or steeply dipping. Bedding is more continuous and uniform at the surface of the fan than within the fan. Bedding is exposed in steep valley walls along entrenched streams where sections show cut and fill structures that probably developed as the stream meandered across the surface of the fan. Clay layers within fan deposits support perched-water tables at different depths.

The material in the large alluvial fan of Ship Creek is finer than the Naptowne outwash in the same area. The fan deposit is composed of silty sand, medium-fine sand with pebbles, and gravelly sand (Corps of Engineers, unpublished drill records, $D H-3, D H-4$, $D H-43$ ), whereas the outwash ranges from sandy gravel to pebble gravel with cobbles.

The fans on the tidal beach at the mouth of streams are predominantly medium sand with pebble lenses.

Fan deposits differ in thickness from place to place and from fan to fan. Those along Ship Creek range in known thickness from about 10 feet to about 35 feet (Corps of Engineers, unpublished drill records, $D H-3$, and $D H-4$ ).

Deposits of the fans along the mountains apparently are related to glacial melt-water streams. The fan along Ship Creek is separated from the abandoned-channel deposits at the mouth of the valley by a scarp about 10 feet high in places. Such a scarp could indicate that the fan is younger than the abandoned melt-water channel, or, more likely, that the fan was deposited by melt-water and headward accumulation of deposits at a gradient different from that of the melt-water channel resulted in erosion of the scarp separating the higher standing channel deposits from the fan. Fans along the North Fork of Campbell and South Fork of Campbell Creeks are contemporaneous with and grade upstream into the Naptowne abandoned-channel deposits. As the melt-waters from the valley 
glaciers emptied onto the lowlands, they deposited their loads and braided their channels. The contemporaneity of the abandonedchannel deposits with the alluvial fans along the mountain fronts dates some of the fans as probably late Wisconsin in age.

The fan deposit at the front of the Elmendorf Moraine was deposited when the glacier front was a short distance behind the moraine. The source stream flowed through the abandoned channel is sec. 26 , T. 14 N., R. 3 W. Additional melt water flowed through the smaller channel in sec. 27.

The alluvial fans on the tidal beaches are modern fans deposited where the modern streams change gradient at the beach level.

\section{RECENT DEPOSITS}

\section{SWAMP DEPOSITS}

Swamps are widespread throughout the lowlands, along valley streams, and along edges of lakes and ponds. Closed swampy depressions are abundant on most glacial deposits in the area, and some swamps, in addition, are even found on low rounded hills and ridges of ground moraine of the Knik glaciation. The largest swamps are in the lowland area south of Anchorage. Smaller swamps, common everywhere, are most conspicuous along the terraces entrenched into the Naptowne outwash, along the Naptowne abandoned channels, and in the Naptowne ground moraine north of the Elmendorf Moraine. Both the lowland and valley swamps and muskegs have a flat or concave surface that is bounded by upward sloping ground. Depressions within this surface contain small lakes: or ponds. Even though irregularly shaped with indentations and crenulations along their margins, the lowland swamps tend to have: an overall circular outline.

Smaller swamps in kettles in the surface of the lateral moraine and ground moraine of the Knik glaciation, and the end moraine and ground moraine of the Naptowne glaciation tend to be more or less. elongate or circular in outline.

Swamp deposits in the area are predominantly a brown, locally peaty, organic accumulation. Woody tissues, silt, and clay combine in places to make slime. Some peat deposits contain volcanic ash layers; two light-gray layers three-eighths to one-half inch thick were exposed as the peat was removed from a kettle during construction of the International Airport. The first layer was 18 inches below the top of the peat deposit, the second layer 6 inches below the first. Volcanic ash is also recorded in the profiles of muskegs by Dachnowski-Stokes (1941).

Dachnowski-Stokes (1941, p. 3-5) classified Alaskan muskegs into three categories: slope muskegs, raised muskegs, and flat or valley 
muskegs. His classification is based on topographic, structural, and developmental differences. Slope muskegs have sloping surfaces, develop on gently undulating sloping land only slightly above sea level, on slopes of mountain islands. Cool summers, high precipitation, and high humidity are required. Raised muskegs have convex surfaces and contain hummocks of sphagnum moss that continuously grow upward until they are several feet thick. Though raised muskegs develop in less wet conditions than the slope muskegs, high humidity, strong acid reaction of the waters, and lack of mineral salts are required. Flat or valley muskegs have flat or concave surfaces. The height to which the surface of any muskeg can grow is dependent on the ground-water level coupled with the inability of the vegetation to grow above the local water table. Though similar to slope muskegs, environmental requirements of flat muskegs differ in that they are limited to lowlands, stream valleys, and the edges of slightly acid lakes or ponds.

The muskegs and swamps in the Anchorage lowlands are classified as part of the flat or valley-group muskegs (Dachnowski-Stokes, 1941, p. 5). Two muskeg localities in the Anchorage area, one near Lake Hood and Lake Spenard, the other on the abandoned-channel deposits below Merrill Field are described in detail by DachnowskiStokes. The swamp around Lake Hood and Lake Spenard (Dachnowski-Stokes, 1941, locality no. 33, p. 54) is over 11.5 feet deep and consists of partly decomposed hypnum peat (70 inches), sedge peat (52 inches), plus sphagnum moss at the surface. The profile through the center of a muskeg near Merrill Field gave an average thickness of 6 feet of peat over a sandy gravel (Dachnowski-Stokes, 1941, p. 55). General descriptions of other muskeg soundings near Merrill Field (op. cit. p. 55) indicate that the swamp deposits along stream valleys, though shallower than those in kettles and other pond depressions, consist principally of sphagnum moss, peat, and sedge peat. The marginal parts are about 30 inches deep as compared to the 140 inches around Lake Spenard.

Dachnowski-Stokes (1941, p. 56, footnote) mentions at least three seams of volcanic ash in the peat along Knik Arm near Point Woronzof.

The profiles listed by Dachnowski-Stokes (1941, p. 54-55) show at least one muskeg to be 11 feet thick (Merrill Field No. 34). A rod driven by the present authors into muskeg along the Seward to Anchorage Highway in sec. 30, T. 13 N., R. 3 W., penetrated more than 12 feet without reaching the underlying glacial materials, whereas in sec. 24, T. 12 N., R. 3 W., the muskeg is about 4 feet thick. Near Point Woronzof, 14 feet of peat overlies the Bootlegger Cove clay. The thickness of the swamp deposit depends on the type of depression or surface on which the swamp formed. As a general 
rule, the valley muskegs are thinner than the lake or pond muskegs. The lowland muskegs that overlie the older ground moraine are also thinner than the pond muskegs. A carbon-14 determination of a peat sample taken from the lower foot of an 8-foot peat exposure at the International Airport was measured as 5,340 \pm 300 years (Kulp, and others, 1951, 101A, p. 568). The sample was taken from the drainage ditch through a muskeg on the east side of the north end of the north-south runway. Plant growth and encroachment by swamp deposits are still in progress in other swamps. Thus, the carbon-14 date indicates the minimum radiocarbon age of the peat in that particular depression. It does not indicate the age of the depression in which the peat accumulated, or the age of the entire thickness of peat. The ages of the swamp deposits probably are restricted to the Recent epoch.

Most swamps form by encroachment of aquatic and semiaquatic vegetation onto lakes and ponds that were formed in small and large kettles and in depressions along stream valleys where the water table is shallow. In time, the water becomes slightly acid with a low content of soluble mineral salts. Plants encroach and spread across low ridges in the lowland and move toward the center of the depression, filling it until only a small lake or pond remains a vestige of a larger lake (Dachnowski-Stokes, 1941, p. 53). The muskeg is restricted in height and lateral extent by an apparent inability to grow above the local water table. He states (1951, p. 4) :

The normal succession is from aquatic peat-forming plant communities to transitional stages dominated by sedges, rushes, and grasses. The later stages begin with the appearance of characteristic sphagnum mosses and their associates. This is correlated with marginal colonization by heaths and conifers. An increasing density in shrubs or trees may eventually kill out the sphagnum mosses in the ground cover.

\section{DUNE SAND}

Dunes extend discontinuously along the bluff of Turnagain Arm from Point Campbell to a position about a mile southeast of Furrow Creek. The only other dune mapped is one on the bluff north of the Eagle River Flats near Clunie Creek. In most places, the dunes are grass covered and stabilized. Where exposed in blow-outs or in sea-cliffs, they are composed of light-tan fine silty sand. The beds are inclined into the hill at about $30^{\circ}$ to $40^{\circ}$ and parallel the surface of the leeward side of the dune. Rootlets extend throughout and thin layers of peatlike material are commonly interbedded in the sand.

Along the bluff of Turnagain Arm, just east of the till hill in sec. 23 , T. 12 N., R. 4 W., a layer of volcanic ash was exposed in a shallow hole in the upper 18 inches of the sand dune. Another ash layer 
about 40 feet above beach level in the bluff along Turnagain Arm in the middle of sec. 7, T. $12 \mathrm{~N}$., R. $4 \mathrm{~W}$. is exposed in the dune sand 8 feet above the base of the dune and 6 feet above a carbon zone.

A narrow steepsided ridge parallel to the edge of the sea cliff is typical of the topography of the most recent sand dunes. The dune sand varies in thickness; on the sea-cliff along Turnagain Arm they range from 3 feet in thickness near the west side of sec. 9, T. $12 \mathrm{~N}$., R. 4 W., to about 45 feet near Point Campbell. Winds carry sand from the fact of the bluff to the top. The sand drops and accumulates as dunes when the velocity diminishes. Near Point Campbell silty sand derived from the underlying delta deposits is being added: to the dune at the present time. On the lee side the dune is encroaching on trees and shrubbery.

\section{ESTUARINE SILT}

Tidal deposits of estuarine silts are exposed almost from bluff to. bluff along Turnagain Arm at low tide, except for the channel of the river that drains Turnagain Arm. Tidal deposits extend alongKnik Arm as well, although their width at low tide is less than. along Turnagain Arm. At high tide the estauarine silt is covered. and only narrow beaches derived from sea-bluff materials extend. along the shores of the arms. At low tide it is uncovered to Fire: Island except for the narrow channels of streams draining Knik Arm.

The longest expanse of estuarine silt above high tide level is. along Turnagain Arm from Potter to about 11/2 miles beyond the. mouth of Campbell Creek. The second largest expanse underlies the: Eagle River Flats. A narrow band parallels the shoreline for about three-fourths of the distance from Point Campbell to Point Woronzof. The flats at the mouths of Fish Creek and Chester Creek, and. between Ship Creek and the Elmendorf Moraine also are composed of estuarine silt that is not covered by high tides. The estuarine: silts above and below high tide level is similar in appearance to the: Bootlegger Cove clay. They are dark greenish gray and clayey with. sand grains scattered throughout. They are plastic and sticky when. wet.

The surfaces of the estuarine silts slope toward the center of the: Knik and Turnagain Arms. Records of wells in the silt above high. tide level indicate that peat or muskeg, locally as much as 10 feet thick, overlies the estuarine silt; the silt, which is about 50 feet thick,.. overlies the Bootlegger Cove clay (Corps of Engineers, unpublished well records Nos. $D H-42, D H-7)$. The estuarine silt accumulated. from the glacial flour carried into Knik and Turnagain Arms by the waters from the melting glaciers. This process of deposition is: still continuing. The estuarine silt above high-tide level probably- 
was deposited by tides when the waters of the arms of Cook Inlet were higher.

\section{ALLUVIUM}

Alluvium is mapped along Clunie Creek, along the Eagle River, between Otter Lake and the Eagle River Flats, and along Sixmile, Ship, Chester, Campbell, Rabbit, and Little Rabbit Creeks. The determining factor in mapping alluvium was the scale of the map. Other streams in the area, as well as the upper reaches of the streams mentioned above, have thin narrow deposits of alluvium that are not mapped. As a generality, the particle size of the alluvium at any one place in the area is coarser than the material into which the stream channel is entrenched. When the entrenched material was reworked by the stream, the finer fraction was removed and carried downstream. The coarser particles remained in the channel alluvium. Seasonal increases in stream volume could accelerate such sorting as well as transport large particles downstream where they commonly are surrounded by deposits of smaller particle size. A 2-foot thick pebble to cobble gravel layer near Spenard Road and Chester Creek overlies sand where the outwash is sand or pebbly sand (Cederstrom and Trainer, 1953, No. 17). Similarly, pebble and cobble gravel is at the surface of a sandy gravel alluvium along Ship Creek that overlies a sand blanketing the Bootlegger Cove clay (Corps of Engineers, unpublished well $\log D H-28$ ). The outwash in this area is a sandy pebble gravel.

Sandy pebble gravel constitutes the alluvium where Campbell Creek flows parallel to the Sand Lake Road. The alluvium is coarser where the creek flows through the lowlands east of the Seward to Anchorage Highway, and it is predominantly a cobble gravel where the stream flows on the Campbell Airstrip alluvial fan.

The alluvium varies in thickness from place to place; near Spenard Road it is 19 feet thick, along Ship Creek in the SE1/4 NW1/4 sec. 9, T. $13 \mathrm{~N}$., R $3 \mathrm{~W}$., it is 17 feet thick. The surface of the alluvium along Ship Creek is flat and slopes from about 38 feet per mile between Walten Road and the Glenn Highway to about 41 feet per mile nearer Knik Arm. This slope is for a line distance parallel to the channel between two points on the alluvium and is not the gradient of the stream channel. It compares with a slope of 32 feet per mile for the Naptowne outwash, and a slope of about 36 feet per mile for the Naptowne abandoned-channel deposits south of Ship Creek.

Streams are slightly entrenched into the pre-Wisconsin deposits in the lowland area south of Anchorage, especially along Campbell Creek north of Dowling Road where the alluvium is below swamp level. Alluvium fills modern stream channels cut in underlying 
deposits. Even though buried channels eroded into the Bootlegger Cove clay locally coincide in part with the courses of the modern streams, the alluvium is primarily a thin fill deposit that covers a surface cut on older materials. The stream cutting and deposition probably resulted from sea-level fluctuations since altithermal time.

\section{LOESS}

Loess is deposited over most of the glacial deposits in the Anchorage area, however, since it ranges in thickness from 0 to only about 3 feet it is not mapped. The source probably was the Knik and Naptowne outwash deposits. Today, clouds of silt can be seen along the flood plain of the Matanuska River as the winds pick up the fine fraction from the dry surface of the river bars. A similar origin is envisioned for the loess in the area.

\section{GEOLOGIC HISTORY}

\section{GLACIAL HISTORY}

The Cook Inlet area probably appeared different at the beginning of Pleistocene time than it does today. Capps (1940) concluded that. the Inlet was narrower, had well-drained border lowlands probably marked by more or less equally spaced stream valleys separated by low hills and ridges. Turnagain Arm was likely a mountain valley, and Knik Arm was, in all likelihood, a stream valley that was above: high tide. The north end of Cook Inlet may have extended northward over the area now occupied by the Susitna lowland delta.

Little is known about possible pre-Eklutna glaciations of the Anchorage area. Rounded summits and spurs at altitudes up to 4,400' feet on Mount Susitna, west of Anchorage, and at other places in the Cook Inlet area, and glacial deposits at altitudes of 3,000 feet near Tustumena Lake, south of Anchorage have been attributed by KKarlstrom (in Péwé, and others, 1953) to two early Pleistocene glaciations. Smoothed spurs and ridges at altitudes of about 2,200 to 2,800 feet along the front of the Chugach Mountains east of Anchorage and deposits of the glacial drift, undifferentiated, may be related to one or both of these proposed advances, but they also. may be related to the Eklutna glacier.

The Matanuska lobe of the Eklutna glacier of Illinoiian(?) age: advanced down Knik Arm through the Anchorage lowland and in all likelihood coalesced below Anchorage with lobes of the Susitna. Valley and Turnagain Arm glaciers. The oldest glacial deposits: exposed in the Anchorage area were deposited by this glacier. Weathering that followed, oxidized the Eklutna drift to depths of at least 40 feet. Erosion locally truncated the Eklutna till and outwash and left benchlike remnants. 
The Matanuska and Knik lobes of the Susitna Valley glacier of Knik (post-Sangamon?, pre-Wisconsin?) age later advanced through the Anchorage lowland and apparently coalesced with the Turnagain lobe. The Matanuska-Knik and Turnagain lobes probably became separated from the larger Susitna Valley lobe as they retreated up Cook Inlet from their point of farthest advance; the Matanuska and Knik lobe moved to a position north of Anchorage, whereas the Turnagain lobe moved an unknown distance up Turnagain Arm. The supply area to the Turnagain Arm glacier is :smaller than that to the Matanuska and Knik glaciers, and the Turnagain glacier probably retreated faster and had little or no influence -on the preserved features in the Anchorage area.

Accumulations of talus and rubble carried by the glacier, and sand :and gravel carried by streams along the flanks of the Chugach Mountains, formed the lateral moraine. Melt water flowing along the margins of the ice reworked some of the glacial materials in the lateral moraine. The lower slopes of the Chugach Mountains were -covered by the debris of the lateral moraine as the Knik glacier thinned. The melt-water streams eroded channels into the lateral moraine, and stratified deposits covered the bottoms of the short channel segments preserved in the lateral moraine. The Knik gla-cier probably withdrew gradually up Knik Arm, but such features :as kames, eskers, and pitted outwash are numerous enough to indi"cate considerable stagnation in the Anchorage area.

Basal till was uncovered along the lower slope of the mountain front west of the lateral moraine as the glacier wasted away. Thin :ablation moraine was deposited on the basal till as the area was deglaciated. Stagnation left scattered blocks of ice in the ground moraine. Melt-water streams were partly controlled by the ice in the area as they cut channels in the till; where the streams flowed -on ice their channels are discontinuous, and segments of channels are all that remain in the ground moraine of the Knik glaciation.

Glacial materials of different lithologies and landforms were deposited or formed concomitantly. At this stage of deglaciation, much of the debris carried on the surface of the glacier was reworked into stratified drift by glacial streams flowing on the ice. Much of this stratified drift accumulated over the ground moraine of Knik age as ice-contact deposits. Some of the crevasses and -depressions in the ice were filled with stream deposits, and others were filled by unsorted glacial debris that tumbled into the openings. Small lakes and ponds on the ice were filled with fluvial, -deltaic, or lacustrine deposits. The end results were hills, ridges, and stratified drift in the form of glaciofluvial ice-contact deposits that cover parts of the Knik ground moraine. Melt-water streams that flowed over the lowland later eroded these deposits. 
A glacier from the west or northwest dammed the waters coming from the Matanuska, Knik, and Turnagain glaciers. The waters accumulated in a basin and covered part of the ground moraine toward the center of what is now Knik Arm. Debris from the glacier deposited as a delta, and rock flour carried into the lake by rivers from the Matanuska and Knik glaciers formed the Bootlegger Cove clay.

The lake either filled and overflowed the delta, or a slight withdrawal of the lobe permitted the lake to overflow along depressions in the delta. The lake first overflowed between Point Campbell and Point Woronzof, but waters overflowing west of Point Woronzof cut into the delta faster and the lake drained along that channel. The lake drained parallel to the west edge of the delta deposits, cut the flat overflow channel surface, and truncated the earlier overflow channel deposits from the lake leaving a scarp separating the two channels. Whether waters from the Matanuska River eroded the Bootlegger Cove clay along the old preglacial valley to reform an ancestral Knik Arm is not known.

Though isolated blocks of glacier ice remained in the lowland area during deglaciation, the Knik glacier melted back to the north. Glacial streams that flowed into the Anchorage area covered parts of the ground moraine with outwash. A pitted surface resulted where outwash was deposited around ice knobs and blocks. There were at least four periods of outwash deposition north of the area. Outwash at the highest altitude was deposited when the source of the melt water was close to the area; two intermediate terracelike levels indicate base-level controls as the glacier melted northward, and the outwash at the lowest altitude was deposited when the source was further north of the Anchorage area.

During the interglacial period that followed, some of the freshwater lakes and ponds on the pre-Wisconsin glacial deposits became brackish and were filled with clay and peat. Also during this interval, diatomaceous clay (p. 18) was deposited in some of the shallow lakes and ponds on the glacial deposits. The surface of the Bootlegger Cove clay was weathered and oxidized.

A pre-Naptowne Wisconsin glacier occupied the Anchorage area and deposited till between the Bootlegger Cove clay and the Naptowne advance outwash. As the Matanuska-Knik lobe of the Naptowne glacier moved toward the Anchorage area, melt water deposited the advance outwash in front of the moving glacier and buried the Bootlegger Cove clay and till deposited by the earlier Wisconsin glacier. The Naptowne glacier then overrode the advance outwash and moved to about the position marked by the Elmendorf Moraine. The ice front fluctuated, but it was stationary for a sufficient time 
to deposit the end moraine. It then retreated, leaving detached stagnant blocks. As these events were taking place, melt water flowed through or over the end moraine from a point west of Cairn Point and deposited the pitted outwash in front of the end moraine. The Matanuska-Knik lobe and its end moraine blocked the drainage of the Eagle River so that a lake formed in the lower part of the Eagle River valley. The lake overflowed and cut channels along the south side of the Eagle River valley. The lake water flowed toward the modern Knik Arm along the south side of the Elmendorf Moraine and cut channels into the Bootlegger Cove clay. The overflow channels along the south side of the Eagle River valley eventually were cut deep enough to drain the lake, and the Naptowne outwash was deposited as a flat plain parallel to the south side of the end moraine. The southwestern and western extents of the outwash beyond the Anchorage plain are not known. The outwash is graded either to a surface higher than modern sea level on Knik Arm, perhaps the northeast slope of the Point Campbell and Point Woronzof highland, or to sea level at some distance down the Arm. About the same time, the fan on the outwash plain in front of the end moraine was deposited by melt waters from the glacier. Contemporaneous with the deposition of the outwash, the melt water flowing from the smaller valley glaciers in the mountains cut channels through and reworked the glacial deposits along the western edge of the mountains. The alluvial fans at Ship, North Fork of Campbell, and South Fork of Campbell Creeks were formed as stream loads were dropped at the mountain front. Relieved of their loads, the streams were capable of cutting channels. Ship Creek or some other melt-water stream flowed across the outwash and cut channels and deposited the alluvium of the abandoned-channel deposits of Naptowne age. Silt and fine sand were available from the broad outwash plain, and winds carried the fine fraction southward and covered parts of the prodelta, delta, and pitted outwash deposits of the Knik glaciation with the windblown silt.

When the melt water flowing from the valley of the Eagle River cut a channel along what is now Fossil Creek, the major deposition of the Naptowne outwash from the Eagle River was stopped. Flow from Fossil Creek along the southern margin of the glacial ice to the west deposited the kame terrace, sequence 1.

The Eagle River changed its course periodically, at some time flowing along each of the abandoned channels that are tributary to the course of the modern Eagle River. These channels also had ice on one wall where the kame terrace, sequence 2, was formed. The channel of sequence 1 was abandoned when the valley of Sixmile Creek was cut. Uneven retreat and wasting of the Wisconsin glacier 
left blocks of ice interspersed with ground moraine, and while the Eagle River was changing its course, small melt-water channels were incised into the ground moraine by streams flowing from the ice blocks. More or less parallel channels in the ground moraine north of the Eagle River were cut either by melt water from wasting ice north of the area or by melt water flowing in channels bounding the ice as the glacier retreated. These melt-water streams apparently joined water from the Eagle River valley and flowed westward into the area now covered by Knik Arm. The lowland at this junction was later (postglacial time) eroded to the embayment that is now the Eagle River Flats.

When most of the ice had wasted away, the streamflow from the Eagle River valley became integrated into a single stream with the result that the Eagle River entrenched itself through its melt-water channel and into the ground moraine and the underlying gravels of Knik age.

Complete wasting of the ice left the basal till of the Naptowne ground moraine covered by unsorted superglacial till. Stream flow became concentrated along the modern courses.

Those morainal deposits and glacial drift deposits, undifferentiated, that are related to the Wisconsin glaciation in the mountains, were deposited as outwash and end moraines from valley glaciers. Stagnation or retreat of the glaciers deposited the glacial drift in the valley bottoms.

\section{POSTGLACIAT HISTORY}

The maximum advance of the Wisconsin glacier in the Anchorage area left much of the area south of the Elmendorf Moraine uncovered by ice. The glacial deposits of Naptowne age either were exposed after the Wisconsin glacier retreated or at various intervals during deglaciation, at which times the glacial deposits were subjected to modification of their original forms by weathering, eolian deposition, plant growth, and erosion. Vegetation started to accumulate in kettles and other depressions. The deposition of loess, which started during the Wisconsin glaciation, for the most part covered the glacial deposits in postglacial times. Where this loess accumulated slowly, moderate podzol soils formed on the loess as well as on the upper part of the glacial deposits.

Erosion in postglacial time is confined, for the most part, to Turnagain and Knik Arms, and to the channels of the modern streams. The age of the erosion that formed the modern Knik and Turnagain Arms is not established, but the relationship of Knik Arm to the Naptowne outwash and the abandoned-channel deposits permits certain inferences. Knik Arm formed after deposition of the Naptowne 
outwash, which was deposited about 11,000 years ago (p. 68), and apparently formed after the abandoned channels were cut into the outwash. The waters of the combined Matanuska and Knik River eroded an everwidening channel into the outwash during deglaciation, or soon after. The waters of Cook Inlet probably eroded the southern limits of the outwash, and shortened the course and steepened the gradient of the river channel, which resulted in downcutting into the outwash. Isostatic adjustment of the surface increased downcutting by the Matanuska-Knik River. The waters of Cook Inlet eventually rose, flooded the valley of the combined MatanuskaKnik River, and tidal waters widened the valley to form the modern Knik Arm. Similarly, erosion by river and tidal waters formed Turnagain Arm. Streams in the mountains are incised into the pre-Wisconsin glacial deposits of Knik age along the flanks of the mountains, and into the glacial drift and morainal deposits, undifferentiated. In adjusting to their new gradients, the postglacial streams eroded bedrock at several places in and near the Anchorage area. The postglacial South Fork of Campbell Creek cut through the overlying abandoned-channel deposits, through the till of the lateral moraine, and into the underlying rock to form a steepsided bedrock gorge about 150 feet deep that is, as far as can be determined, north of its preglacial channel. Likewise, the Eagle River has cut into a preglacial bedrock spur that forms the abutment of the bridge along the old Anchorage to Palmer. Highway (Dobrovolny and Miller, 1950).

Streams in the lowland area have incised their channels slightly into the ground moraine, abandoned-channel deposits, outwash deposits, and locally into the muskegs. Streams that originate in the lowlands south of the end moraine have slightly integrated drainage in areas of large swamps and muskegs. North of the end moraine the drainage in the lowlands is not yet integrated. Kettles and depressions are undrained, and the only graded flow is by modern consequent streams that use as their courses the channels abandoned by the glacial melt waters.

Along Turnagain and Knik Arms steep sea cliffs are being cut as the waters of Knik and Turnagain Arms erode the north, south, and west sides of Point Woronzof and Point Campbell highlands. The rate of recent erosion at Point Woronzof is recorded indirectly in the descriptions of the U.S. Coast and Geodetic Survey ${ }^{6}$ triangulation stations. The Woronzof station was first established on Point Woronzof about 32 feet south of the edge of the bluff in 1909. In 1918 the bluff had receded to the station and a second station,

6 U.S. Coast and Geodetic Survey, Descriptions of triangulation stations, Cook Inlet, southwest Alaska. 
Woronzof $f_{2}$, was established about 41 feet southwest of the Woronzof station. By 1941 erosion had removed the 1909 station and the bluff had receded to a position about 13 feet north of the Woronzof ${ }_{2}$ station. Two reference marks, Woronzof ${ }_{2}$ 1918-41, 1 and 2, were established about 75 feet southwest and 65 feet south-southwest of Woronzof $f_{2}$, respectively. By 1947 Woronzof $_{2}$ had been removed and the bluff had receded along a line about 24 feet and 30 feet, respectively, north of reference marks 1 and 2. In 1947 station mark Woronzof ${ }_{3}$ was established about 67 feet east-southeast of the position of Woronzof . Woronzof $_{3}$ was about 21 feet south of the edge of the bluff. By 1954 Woronzof $_{3}$ had been removed by erosion of the bluff, reference marks 1 and 2 were recovered. In 1955 reference mark 1 could not be found, but reference mark 2 was recovered in position.

From its position in 1909 the bluff receded southward a total of about 95 feet by 1947 (fig. 6), or about 2 feet per year. Because the 1909 position of the bluff line north of Woronzof f $_{3}$ is not known, the amount of erosion since 1947 is not estimated.

A trunk of a tree, 0.6 of a mile from the Fire Island triangulation station northeast along the sea bluff forming the southeast shore of Fire Island facing Turnagain Arm, was buried in an upright position by dune sand. Sampled for a radiocarbon analysis, the age of the tree was determined to be $620 \pm 200$ radiocarbon years (Rubin, Meyer, U.S. Geological Survey, written communication, April 2, $1957 \mathrm{~W}-541)$. Modern sand dunes extend inland almost one-half mile near the Fire Island station. Dead trees extend through the sand about one-fourth mile inland, but partly buried trees further inland still bear foliage. Thus, assuming conditions were similar when the tree that was sampled died, the sea bluff has receded about one-fourth mile in about 600 years, or about 2 feet a year.

Constant undercutting of the sea bluffs by the waters of Knik and Turnagain Arms is slowly removing the materials in the bluffs and reworking them into modern beach deposits below high tides. In addition, spring thaws provide water that saturates the Naptowne outwash and the surface of the Bootlegger Cove clay along Knik Arm. Slumping and sliding of the saturated materials onto the beach, where tide water removes them, also slowly modifies the shoreline each year.

Winds blowing against the eroded bluffs, deposited, and are depositing, sand dunes along Turnagain Arm that parallel the tops of the sea bluff, and along the northshore bluffs facing the Eagle River Flats.

Interpretation of radiocarbon dates of apparent fluctuations in sea level, were made by T. N. V. Karlstrom for the Cook Inlet 
Edge of bluff, 1918

$\triangle$ WORONZOF

1909

\section{EXPLANATION}

Edge of bluff

Accurately located

Edge of bluff

Approximately located

$\triangle$ WORONZOF

1909

Triangulation station

$\Delta_{\text {RM } 1}$

Reference mark

Edge of bluff, 1941
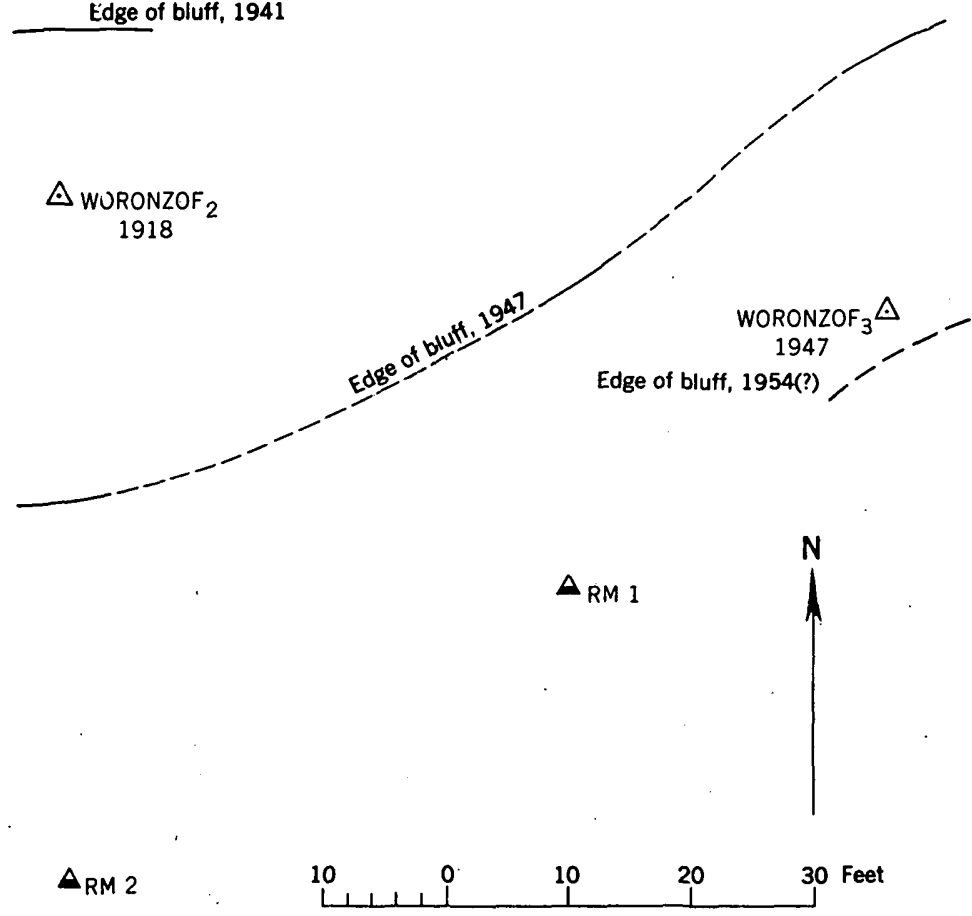

Figore 6.-Positions of receding blufi line at Point Woronzof from 1909 to 1954. Established by positions of bluff line in relation to U.S. Coast and Geodetic Survey triangulation stations Woronzof, Woronzof 2 , and Woronzof 9 . 
region and are here briefly summarized. Collections from tidal bog sections are interpreted by Karlstrom to indicate at least one low level of the sea about 5,000 years ago (3000 B.C.) that corresponds to the Tustumena glaciation (fig. 2). He described a section (in Rubin and Suess, 1956, W-299, p. 445) from which he collected wood as follows:

Wood from near base of forest peat unit exposed above low tide level and overlain in turn by 5 to 6 feet of tidal silt, 2 feet of forest and sedge peat, 6 to 8 inches of tidal silt, and 1.5 to 2 feet of peat with three distinct forest layers becoming distinctly silty near top of section. The tidal bog stratigraphy records a sequence of lower and higher sea-level phases in the Cook Inlet. The lower peat is interpreted as representing the eustatic low sea-level phase during the Tustumena glaciation, which has been dated from other evidence between 3000 and 1 B.C. The new date falls within the time boundaries of the Tustumena glaciation, and substantiates the belief that this glaciation was an important climatic event during the Recent epoch.

Another sample collected near Girdwood by Karlstrom and determined by Rubin and Suess $(1955, \mathrm{~W}-175$, p. 486$)$ is dated as $700 \pm 250$ radiocarbon years. The description and Karlstrom's interpretation (in Rubin and Suess, 1955, p. 486) of the sample reads:

* * * Wood was from a tripartite forest zone overlying tidal silts presumed to be from a glacial minimum. The forests are believed to record a relatively low sea-level stand that was terminated by a period of higher sea level, during which the overlying tidal silts were deposited.

Thus, about 700 years ago a rise in sea level killed the forest. Karlstrom (1955, p. 1582) dates three Recent glaciations in radiocarbon years as between 4,400 years ago (3500 B.C.) and 1,400 years ago (A.D. 500), between 1,400 years ago (A.D. 500) and 400 years ago (A.D. 1500), and between 400 years ago (A.D. 1500) and the present.

The shoreline of Cook Inlet probably has been influenced by eustatic sea-level changes (owing to an increase or decrease of volume of water in the ocean), isostatic rebound (owing to changes in load on the land), and tectonic changes (from mountain building forces). Any of these conditions or combinations of conditions could result in deposits such as those described in the previous paragraphs.

Erosion by waters of Knik and Turnagain Arms have, for the most part, obliterated beaches, strand lines, or other evidences of sealevel fluctuations in the Anchorage area. Trainer (1953, p. 18) finds evidence in the gradients of stream terraces at about the level of the Matanuska River and Knik Arm that the sea into which those streams flowed was at a lower level than now. In addition, he cites bars as evidence of a higher sea level than at present.

$507199-60-7$ 


\section{ECONOMIC GEOLOGY}

\section{MINERAL RESOURCES}

The mineral resources in the Anchorage area are nonmetallic and, for the most part, are related to the glacial deposits that cover most of the lowlands and the flanks of the mountains. Though lode and placer deposits of metallic minerals have been worked along both sides of Turnagain Arm, no such deposits are known to exist in the area under investigation.

\section{COAL}

Coal was mined just east of the mapped area near the Alaska Railroad bridge that crosses the Eagle River. The mine is now abandoned and caved. Coal-bearing Tertiary rocks are exposed along the river from the Alaska Railroad bridge to the Glenn Highway bridge (Dobrovolny and Miller, 1950), but the seams disappear under the glacial deposits before reaching the mapped area. No coal beds are known to crop out in the Anchorage area. Coal probably underlies the area, though the depths to rocks of Tertiary age, as recorded in wells, range from about 230 feet near the mouth of the Ship Creek valley (U.S.G.S. No. 10, Ski Bowl Road, Corps of Engineers, written communication, February 1957), to 447 and 766 feet (Cederstrom and Trainer, 1953, No. 173; Corps of Engineers, unpublished well record, West Power Plant well), toward Knik Arm.

Coal reported at Point Campbell and Point Woronzof and in excavations or shallow wells in and around Anchorage, is not in seams, but is either in layers of water-transported coal fragments interbedded with sand and gravel of Pleistocene age, or occurs as large blocks of coal, some pieces of which are as much as 6 feet in longest dimension, that were likewise transported by water, or by glaciers.

\section{LIMESTONE}

Within the pre-Cretaceous(?) rocks, three areas of limestone exposures are mapped along Turnagain Arm and Little Rabbit Creek. The exposures extend up to Little Rabbit Creek from a point 300 feet north of the Seward to Anchorage highway. About three-fourths of a mile from the road, the limestone is so interlayered with graywacke that it is difficult to recognize.

In June 1949, one of the authors accompanied Mr. Thomas Mely to his 4 claims on Little Rabbit Creek where 3 assorted samples were collected from the south side of the creek. Mr. John J. O'Shea, assayer, Territorial Bureau of Mines, analyzed the samples and reported 51.1, 64.0, and 63.0 percent residue insoluble in hydrochloric acid. 
Another small outcrop of limestone, metamorphosed almost to marble, is exposed on the mountain 70 feet below the Anchorage to Seward Highway one-fourth of a mile south of Little Rabbit Creek. It was also sampled, and O'Shea reported 4.2 percent of insoluble residue and 95.8 percent calcium carbonate. This exposure shows evidence of being worked years ago, and the remains of an old lime kiln near this outcrop suggests that this is the exposure reported by Martin (1919, p. 27) as being used for the local production of quicklime.

The limestone sample from this small exposure was badly fractured and not satisfactory for building stone.

A brief reconnaissance was made along the mountain area at an altitude higher than the glacial deposits, and although no other limestone beds were seen, the high quality limestone south of Little Rabbit Creek certainly suggests the possibility that other high quality limestones may be in the area.

\section{PEAT}

Peat deposits and muskegs are scattered throughout the lowlands around Anchorage. Because the humic horizon of the soil on the glacial deposits is weakly developed, the addition of peat is beneficial. Sphagnum and sedge moss peat constitute most of the muskeg deposits and can be removed from muskegs on hills and slopes with comparative ease. Shallow ditches through the muskegs provide drainage. The peat will settle as the water is removed, especially if the peat is coarse and fibrous and the ditches are deepened from year to year. The flat muskeg, common in the Anchorage area, is more difficult and expensive to drain than the raised or sloping type of muskeg because it is in a closed basin, and the outlet drains have to be trenched through the surrounding high ground. Such drains slump and fill and require frequent maintenance.

\section{MARL}

Marl was reported along the margins of Otter Lake by Martin (1919, p. 27), and in 1918 (1920, p. 27) agricultural lime was dug from the marl deposit. The only mention by Moxham and Eckhart (1956, p. 18) of marl in the Anchorage area is the deposit in Otter Lake. They show a measured section from the field notes of Martin that indicates 10 feet of marl over sand and gravel. No reserves were estimated for the Otter Lake deposit.

\section{WATER}

Anchorage obtains its water supply from Ship Creek, as do Elmendorf Air Force Base, and Fort Richardson. A report by the Anchorage City Planning Commission (1955) states that the average 
daily consumption of water in the area served by the Anchorage water system was 7.4 million gallons per day, with the maximum consumption at over 9.0 million gallons per day. Twelve million gallons per day are taken from Ship Creek at the intake dam; however, in the winter the available flow has been as low as 6.7 million gallons per day.

Springs and seeps are common along Knik Arm, but the largest spring in the Anchorage area is the Russian Jack Springs in the lowland west of the Prison Farm. The flow from this spring is estimated at about 2.8 million gallons per day and has a constant temperature of from $37^{\circ}$ to $38^{\circ} \mathrm{F}$. (City Planning Commission, 1955, p. 14).

The geology in the Anchorage area is such that unconsolidated glacial materials fill the Cook Inlet trough to depths of over 500 feet. Not all of the unconsolidated material, however, is loose or permeable. Silty and compact glacial till, ponded deposits, and silty and compact gravel are all relatively impermeable. Conversely, within the till, above and below ponded deposits, and intermixed with silty gravel, permeable beds are common.

The U.S. Geological Survey has drilled test wells in the area and has collected well-log data as part of a study of the geology and ground-water resources of the Anchorage area. A 333-foot well put down in the till of the end moraine (Elmendorf Moraine) near Elmendorf Air Force Base penetrated little permeable material. Five feet of water-bearing sand and gravel was found between 105 feet and 110 feet (Cederstrom, 1952, p. 21).

At Mountain View, a well 154 feet deep through the Naptowne outwash and Bootlegger Cove clay has a flow of 104 gallons per minute; a shallow well, 51 feet deep, yields 35 gallons per minute to a pump; another well, 44 feet deep, yields 30 gallons per minute (Cederstrom, 1952, p. 21). Typically, many wells drilled in the outwash for domestic use are shallow-20 to 70 feet deep-(Cederstrom and Trainer, 1953, wells 26, 28, 29, 33, 34) and obtain their water from the perched-water table overlying the Bootlegger Cove clay. The well near the junction of Spenard Road and the KFQD Road is an exception. It passed through the Bootlegger Cove clay and obtained water from a gravel apparently interlayered with the underlying till. The well yields 13 gallons per minute with a drawdown of water table of 40 feet (Cederstrom and Trainer, 1953, well 46, table 1, p. 3). Another exception is the well at a trailer court west of Fish Creek where a well went through the Bootlegger Cove clay and yielded 10 gallons per minute, with a drawdown of only $31 / 2$ feet, from a sand and gravel beneath the clay (Cederstrom and Trainer, 1953, well 78, table 1, p. 5). Another well in Turnagain Heights penetrated a sand and gravel below (or within) the Bootlegger Cove 
clay that yielded 40 gallons per minute of brackish water with a drawdown of 12 feet (Cederstrom and Trainer, 1953, well 50, table 1, p. 4).

The Spenard area is one of the largest areas bordering Anchorage that is not served (1956) by water or sewer service (City Planning Commission, 1955, p. 24). Much of the domestic water is obtained from gravel in shallow wells above the Bootlegger Cove clay. Cesspools return the waste materials to the same aquifer. The waste percolates downward until the surface of the Bootlegger Cove clay deflects the material laterally along with the ground water (fig. 7). Thus, one domestic water supply may be another's waste. Some drilled wells obtain water from beneath the Bootlegger Cove clay. More such deep wells, or water supplied by the City of Anchorage, would alleviate this situation, and remove unsanitary conditions.

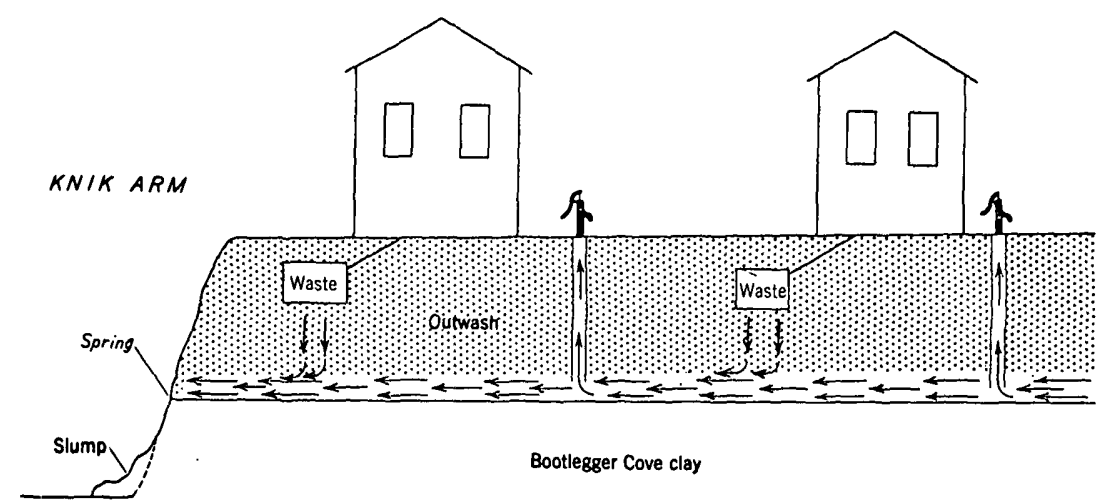

Fisune 7.-Diagrammatic sketch showing relationship of ground-water movement to upper surface of the Bootlegger Cove clay where clay is overlain by outwash.

\section{CONSTRUCTION MATERIALS}

\section{BRICK CLAY}

In 1917, bricks were made in Anchorage from local clay (Martin, 1919, p. 27). It seems probable that the Bootlegger Cove clay was used then for this purpose, as it was in 1949 when the authors first visited the area. A small brick plant along Knik Arm then was manufacturing brick for local use. The bricks had good color and had bearing strength sufficient for low buildings.

\section{RIPRAP}

Riprap is the term used for large rocks piled in a layer to protect slopes, fills, or other embankments from erosion.

The undifferentiated metamorphic rocks are used for riprap where the Seward to Anchorage Highway and the Alaska Railroad 
parallel Turnagain Arm. The ease of accessibility makes the material an economical source for riprap, although so badly fractured that specimens could not be obtained for toughness or compression tests.

A sample of the metamorphosed limestone exposed 11/4 miles north of Potter was tested by the Bureau of Public Roads. Mr. E. F. Kelley, chief, Physical Research Branch, reported (written communication, May 15, 1950) that the sample was badly fractured and not recommended for riprap. (See table 3.)

Boulders in glacial till are another source of riprap. The boulders range from 1 to 6 feet in the longest dimension and can be used as is, or can be broken into angular fragments.

\section{CRUSHED AGGREGATE}

The undifferentiated metamorphic rocks and the metamorphosed limestone are both satisfactory for use as crushed aggregate. The crushing operation would cause the rock to fracture along existing zones of weakness, and the final aggregate would be acceptable. E. F. Kelley reported (written communication, May 15, 1950) that both of these materials tested were acceptable as concrete aggregate. The glacially transported boulders should be equally suitable sources for crushed aggregate inasmuch as they are commonly composed of resistant argillite, graywacke, greenstone, and other metamorphic rock.

Most of the stratified deposits, regardless of age, contain a coarse fraction that can be crushed for use as aggregate. The primary constituents of the abandoned-channel deposits near Goose Lake and of the outwash, of Naptowne age, and the delta of Knik age are quartzite, greenstone, and vein quartz. (See table 4.)

Though not tested, the following stratified deposits contain materials suitable for use as crushed aggregate: the outwash and kame terraces of Naptowne age, the glaciofluvial ice-contact deposits, the delta deposits, and both cycles of the pitted outwash, all of Knik age.

E. F. Kelley reported (written communication, May 15, 1950) that the undifferentiated metamorphic rocks and the metamorphosed limestone are suitable as aggregate for bituminous construction if an antistripping additive is used with the undifferentiated metamorphic rocks. The abandoned-channel deposit exposed in the pit in the NW1/4 sec. 28, T. 13 N., R. 3 W., was sampled and tested by the Alaska Road Commission. The crushed aggregate was reported as satisfactory for use in bituminous construction (table 3).

No additional tests of materials for bituminous construction are available, but it is probable that deposits of the outwash and kame terrace of Naptowne age, both sequences of the pitted outwash, the 
ECONOMIC GEOLOGY

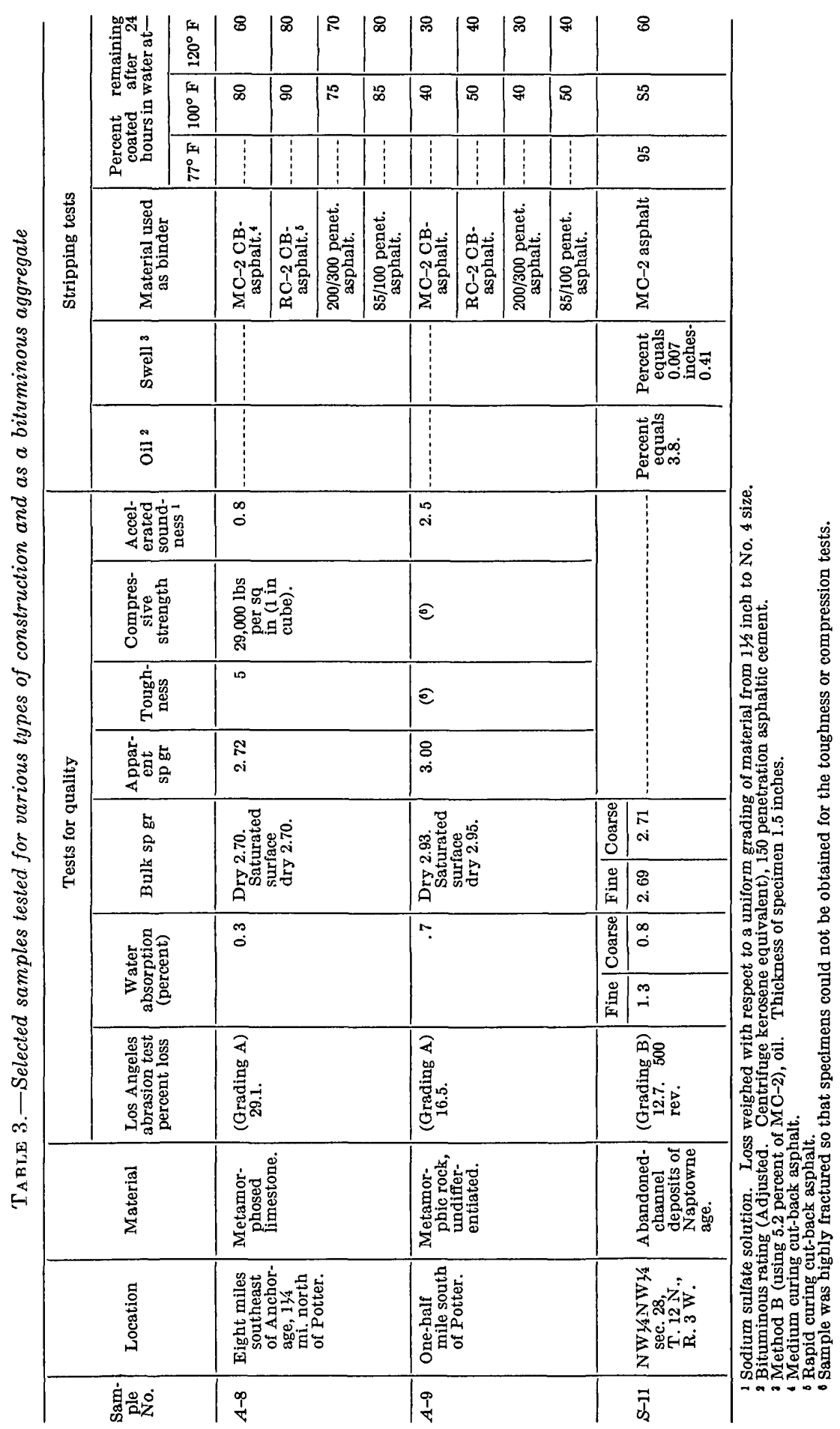




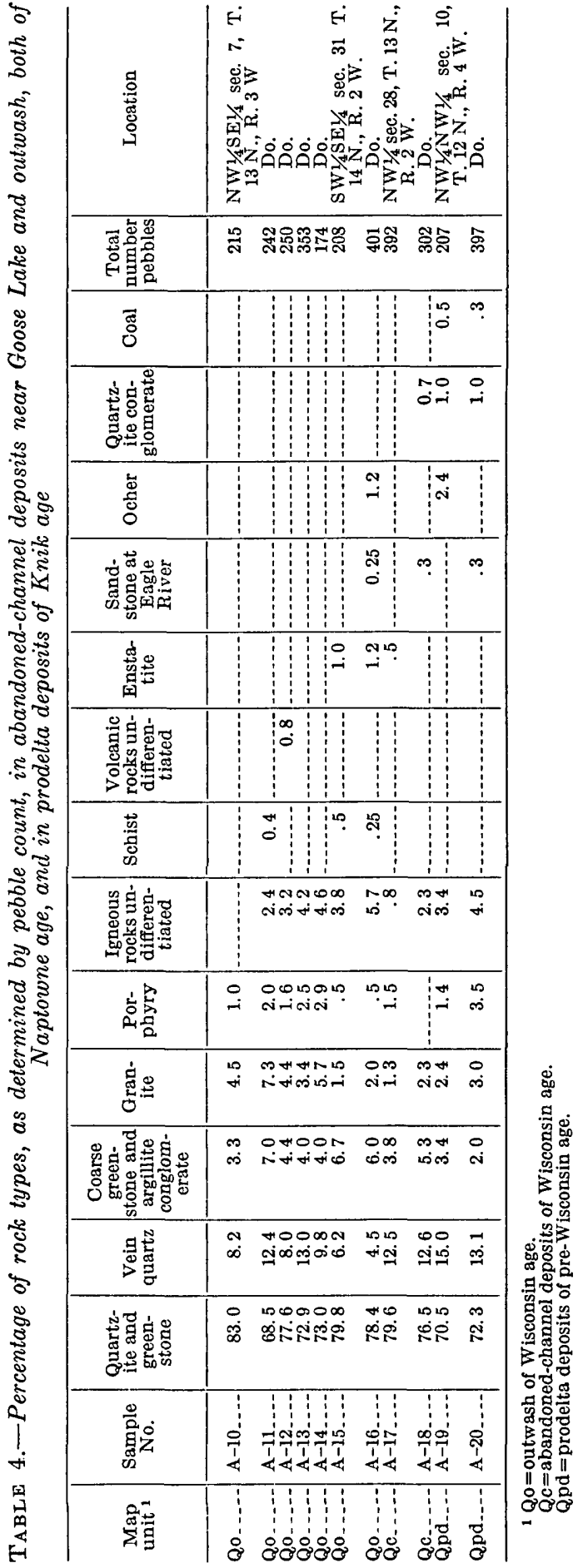


glaciofluvial ice-contact deposits, the prodelta and delta deposits of Knik age would test as suitable for use in bituminous construction, though perhaps with the use of antistripping additive.

\section{SAND AND GRA VEL}

Deposits of sand and gravel (pebble size or larger) are abundant throughout the area. Those deposits that contain fractions : predominantly smaller than 1 inch are chiefly dune sand, and alluvium along the lower course of Campbell Creek, both of Recent age; the outwash, especially west of Chester Creek, and pitted outwash, both of Naptowne age; and locally the outwash, prodelta deposit, delta, and the glaciofluvial ice-contact deposits of Innik age. These deposits are the most likely sources of blending sand, fine aggregate for concrete, and mortar sand (table 5).

Coarser fractions are common in deposits of the Naptowne kame terrace, outwash, especially east of Chester Creek, and locally in the Knik delta deposit, prodelta deposit, and glaciofluvial ice-contact deposits. These deposits are the most likely sources for material for use in subbase course, base course, surfacing; coarse aggregate for concrete, and road metal.

\section{FIIL}

Material used for highway fill in the Anchorage area consists of till of the end moraine, Naptowne ground moraine, Knik ground moraine, and the undifferentiated metamorphic rocks. The till, where allowed to stand over winter before surfacing, settles and compacts. Alluvial fan deposits, and channel deposits in the Knik ground moraine are other possible sources of fill.

\section{BALLAST}

The ballast of the Alaska Railroad along Turnagain $\mathbf{A r m}_{i}$ is broken undifferentiated metamorphic rock. The coarse fraction of the stratified drift in the area should prove satisfactory as ballạst, especially when crushed.

\section{SOIL BINDER}

Binder for use with aggregate in road surfacing materials must be predominantly silt- and clay-size materials. A possible though untested source of binder is the silt in the vicinity of the International Airport. Some of the silt layers in the delta deposit may also be satisfactory.

\section{ENGINEERING PROBLEMS}

\section{FOUNDATION CONDITIONS}

Most of Anchorage is built on the smooth flat.surface of the outwash plain of Naptowne age. The residential and business struc- 
100 SURFICIAL GEOLOGY OF ANCHORAGE AND VICINITY, ALASKA

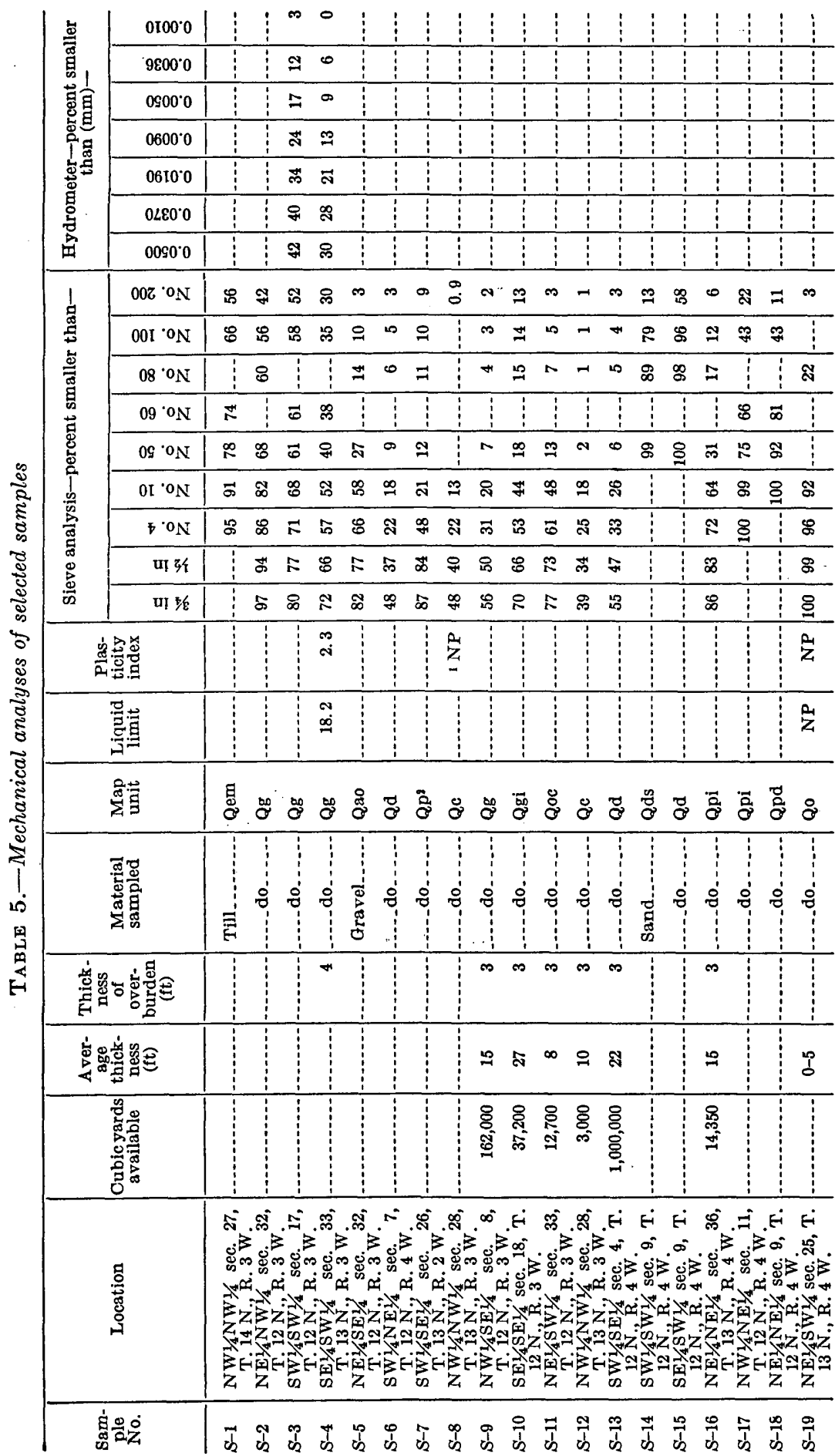




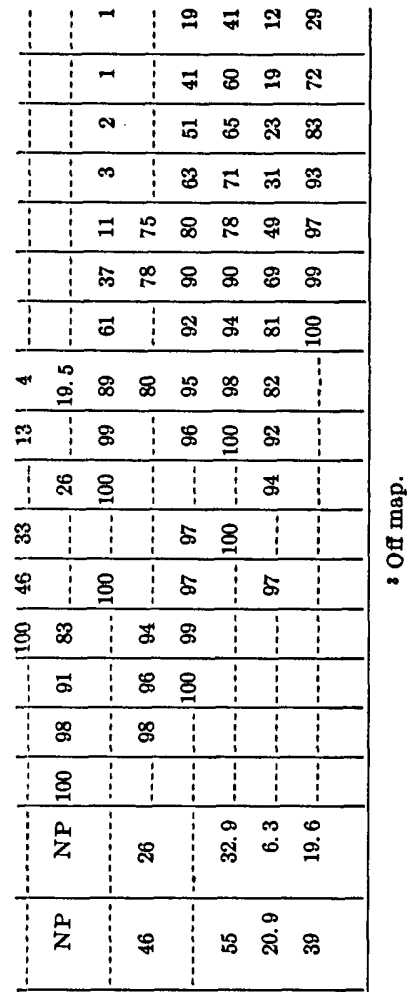

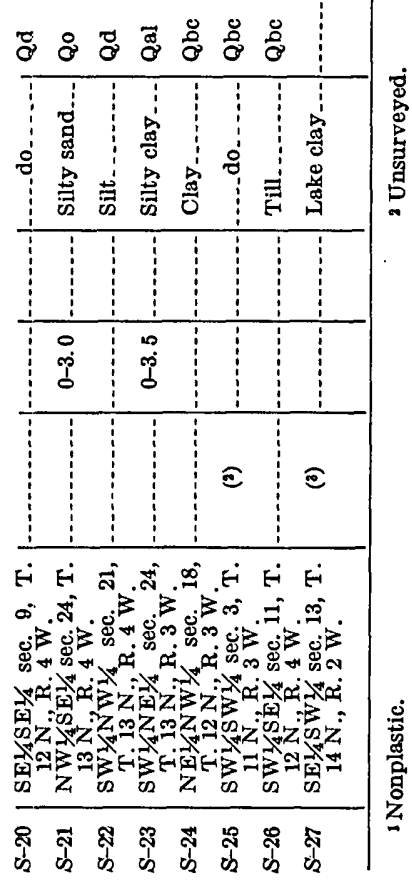


tures built on and founded in the outwash show no failures. The outwash is well sorted and stabilized, and is considered a good foundation material. In general, most of the stratified drift deposits can be considered as good foundation material for small structures:

Underlying much of Anchorage beneath the outwash is the Bootlegger Cove clay (pl. 5). An undisturbed sample of the clay (A-28) collected from the NE1/4 NW1/4 sec. 23 , T. 13 N., R. 4 W., by the authors in 1949 was tested by C. R. Fricke, Laboratory Soil Engineer, Soils Laboratory of the State Highway Commission of Kansas, for physical properties and triaxial compression. The results are tabulated as follows:

\begin{tabular}{|c|c|c|c|c|c|c|c|c|c|c|c|}
\hline $\begin{array}{c}\text { Liquid } \\
\text { limit }\end{array}$ & $\begin{array}{c}\text { Plastic } \\
\text { limit }\end{array}$ & $\begin{array}{c}\text { Plastic } \\
\text { index }\end{array}$ & Sp gr & $\begin{array}{c}\text { Shrink- } \\
\text { age } \\
\text { limit }\end{array}$ & $\begin{array}{c}\text { Shrink- } \\
\text { age } \\
\text { ratio }\end{array}$ & $\begin{array}{c}\text { Volu- } \\
\text { metric } \\
\text { change } \\
\text { (percent) }\end{array}$ & $\begin{array}{c}\text { Lineal } \\
\text { shrink- } \\
\text { age } \\
\text { (percent) }\end{array}$ & $\begin{array}{c}\text { Field } \\
\text { moisture } \\
\text { content }\end{array}$ & $\begin{array}{c}\text { Angle of } \\
\text { internal } \\
\text { facture } \\
\text { (degrees) }\end{array}$ & $\begin{array}{c}\text { Cohesion } \\
\text { (Ibs per } \\
\text { sq ft) }\end{array}$ \\
\hline 39 & 22 & 17 & 2.73 & 20 & 1.68 & 33 & 9 & 35 & 22 & 1,150 \\
\hline
\end{tabular}

The relatively low cohesive strength should be taken into consideration in the design of large structures that are to have footings in the Bootlegger Cove clay.

The Bootlegger Cove clay also underlies much of the Elmendorf Air Force Base, the area around the International Airport, and the outlying suburbs of Anchorage. South of Jewel Lake it is comparatively thin, however, and can be penetrated so that footings of the larger structures could be placed in the underlying sand and gravel.

Two other materials that are potential troublemakers are the tills of both the Knik and Naptowne glaciations, and the windblown silt around the International Airport area. The till, though commonly compact, locally contains an excess of silt that might cause settlement if wetted to extremes. No tests were made and inasmuch as no failures of residential structures built on till were noted by the authors, the till may provide a satisfactory foundation for small structures. The silt is similar to loess and, though not tested, would probably settle if wetted excessively.

Small homes have been constructed successfully on the margin of swamps in the outlying areas around Anchorage. Rafts are used as a type of floating foundation and the residential structures are built on the raft. Those structures seen by the authors appeared to be successful. In some cases the muskegs can be drained by ditches and the peat allowed to settle before construction is started. The foundations should still be placed on the material underlying the peat wherever possible. Other muskegs have been excavated and backfilled where conventional construction was planned. Complete 
removal of the peat deposit is the only certain way to safeguard the structure in such an area.

\section{EXCA VATION}

All of the unconsolidated materials in the Anchorage area can be excavated with the use of power equipment. The well-sorted and stratified deposits, such as outwash, glaciofluvial ice-contact deposits, kame fields, and kame terraces, can be excavated with a power shovel or bulldozer. The less well-sorted unstratified drift, such as the ground moraine, and end moraine of the Naptowne glacier, and the lateral moraine, and the ground moraine of the Knik glacier, may be more compact, but can still be excavated with power shovels or bulldozers. Large boulders within the till may require breaking before removal and loading by the power equipment.

The Bootlegger Cove clay is tough and resistant to power shovels, but can be excavated by scraping with a bulldozer, and, with more difficulty, with power shovels. The clay is compact, and breaks with conchoidal fractures into chunks and blocks when dry; when wet it is soft and sticky, adheres to the equipment, and is difficult to remove. Power equipment may bog down when the clay is wet and saturated.

\section{SLUMPS AND FLOWS}

Conspicuous slump and earthflow (Varnes, D. J., 1958) areas are indicated on plate 1. Movement of a mass is considered slump where the earth mass moves downslope, or rotates with little downward sliding, as a unit or several subsidiary units; the movement is considered an earthflow where the mass is predominantly fine-grained material in which the moisture content is sufficiently great to cause viscous movement downslope. Seasonal slumps, slides, and flows, are active along Knik Arm from about Fish Creek to the western limit of the Bootlegger Cove clay (pl. 10) and north of Anchorage. An old slide block, with recurring movement, forms the "bench" along Knik Arm between Chester Creek and Ship Creek. Other ancient slump blocks extend along the bluffs bordering Chester and Ship Creeks, along the bluff west of Fish Creek, along the bluff of Knik Arm where another "bench" extends from about the Government Dock to the Elmendorf Moraine.

In each area mentioned, the Bootlegger Cove clay-an unstable material when wet, that can be dislodged by some triggering actionunderlies stratified sand and gravel. Slumps and flows along Knik Arm are generally caused by seasonal saturation of the Bootlegger Cove clay. The outer 3 to 5 feet of the clay is hard and frozen during the winter, but becomes wet and plastic during the spring thaw from the moisture within the clay. In addition, when the 
snow cover melts, much of the melt water moves downward through the sand and gravel to the surface of the clay. Lateral movement of the water produces seeps and springs in the bluff at the contact between the sand and gravel and the Bootlegger Cove clay. This additional water completely saturates the already wet outer few feet of the clay. In 1949, one of the authors started a slump and flow by merely walking along the edge of the bluff. Stabilization would eventually result as the debris accumulated along the toe of the bluff. Such an accumulation would tend to prevent further slippage by acting as an opposite force, but unfortunately, much of the slump and flow debris is removed by the tides in Knik Arm, so that an unstable condition is maintained or aggravated. Thus, the positio. of the bluff along the arm is slowly moving landward each year, slowly in most places, but locally as much as 3 feet a year.

Some of the slumping and flowage could be forestalled, or perhaps prevented, by the installation of drains in the catchment area behind the bluff. Such drains could divert the flow of melt water, and much of the normal ground water, to controlled outlets along the bluff. This would reduce the amount of water saturating the clay during the spring thaw.

Groins or pilings placed along the beach line might aid in preventing the removal of the slump and flow debris on the beach by breaking the force of the tidal waters and changing the currents. Careful study should be made before installation of groins or pilings, however, as deposition might result on one side of the groin whereas erosion might remove the beach on the other side.

Shocks, such as those associated with earthquakes, will start moving material that under most conditions is stable. Mild shocks may be sufficient to free contained water in a saturated or nearly saturated material, thereby providing the necessary lubricant for the slide or slump surface. Stronger shocks may be strong enough to exceed the shear strength of dry material and cause it to move.

Anchorage is in an earthquake region, and numerous tremors and shocks of varying intensity have been reported or recorded. (See table 6). Earthquakes are reported by the degree of intensity. One of the most used intensity scales is the Modified Mercalli Scale of Wood and Neumann. Byerly (1942, p. 57-58) abridges Wood and Neumann (1931) as follows:

I. Not felt except by a very few under especially favorable circumstances. II. Felt only by a few persons at rest, especially on upper floors of bulldings. Delicately suspended objects may swing.

III. Felt quite noticeably indoors, especially on upper floors of buildings, but many people do not recognize it as an earthquake. Standing motor cars may rock slightly. Vibration like passing of truck. Duration estimated.

IV. During the day felt indoors by many, outdoors by few. At night some 
awakened. Dishes, windows disturbed; walls made cracking sound. Sensation like heavy truck striking building. Standing motor cars rocked noticeably.

V. Felt by nearly everyone; many awakened. Some dishes, windows, and so forth broken; a few instances of cracked plaster; unstable objects overturned. Disturbance of trees, poles, and other tall objects sometimes noticed. Pendulum clocks may stop.

VI. Felt by all ; many frightened and run outdoors. Some heavy furniture moved; a few instances of fallen plaster or damaged chimneys. Damage slight.

VII. Everybody runs outdoors. Damage negligible in buildings of good design and construction; slight to moderate in well-built ordinary structures; considerable in poorly built or badly designed structures; some chimneys broken. Noticed by persons driving motor cars.

VIII. Damage slight in specially designed structures; considerable in ordinary substantial buildings with partial collapse; great in poorly built structures. Panel walls thrown out of frame structures. Fall of chimneys, factory stacks, columns, monuments, walls. Heavy furniture overturned. Sand and mud ejected in small amounts. Changes in well water. Persons driving motor cars disturbed.

IX. Damage considerable in specially designed structures; well designed frame structures thrown out of plumb; great in substantial buildings, with partial collapse. Buildings shifted off foundations. Ground cracked conspicuously. Underground pipes broken.

$\mathrm{X}$. Some well-built wooden structures destroyed; most masonry and frame structures destroyed with foundations; ground badly cracked. Rails bent. Landslides considerable from river banks and steep slopes. Shifted sand and mud. Water splashed (slopped) over banks.

XI. Few, if any (masonry), structures remain standing. Bridges destroyed. Broad fissures in ground. Underground pipe lines completely out of service. Earth slumps and land slips in soft ground. Rails bent greatly.

XII. Damage total. Waves seen on ground surfaces. Lines of sight and level distorted. Objects thrown upward into the air.

In October 1954, a strong earthquake damaged structures in Anchorage. One of the buildings damaged was the International Airport Building; damage was minor and consisted only of cracking of concrete blocks, no structural damage was done to the load-bearing walls. ${ }^{7}$ In addition to damage to masonry buildings; i.e., fallen plaster and cracked concrete walls, there were several slides along the Alaska Railroad in the Anchorage area. Slides in fill at miles 102.8 and $103.1^{8}$ along the steep till bluff of Turnagain Arm left 140 feet of track suspended 15 to 20 feet $^{\theta}$ in air. In addition, part of the subgrade slid out on the Bootlegger Cove clay between Chester Creek and Ship Creek.

Movement not related to earthquakes was noted along the road in the NE1/4 SE $1 / 4$ sec. 8, T. 13 N., R. 4 W., where a timber retaining wall was displaced by a combination of slumping of the Bootlegger Cove clay and slumping in the oversteepened slope cut into the overlying outwash.

7 Anchorage Dally Times, October 6, 1954.

B T. L. Pewé, oral communication.

o Anchorage Dally Times, October 4, 1954. 
106 SURFICIAL GEOLOGY OF ANCHORAGE AND VICINITY, ALASKA

TABLE 6.-Records of earthquakes reported in Anchorage, ${ }^{1} 1996-54$

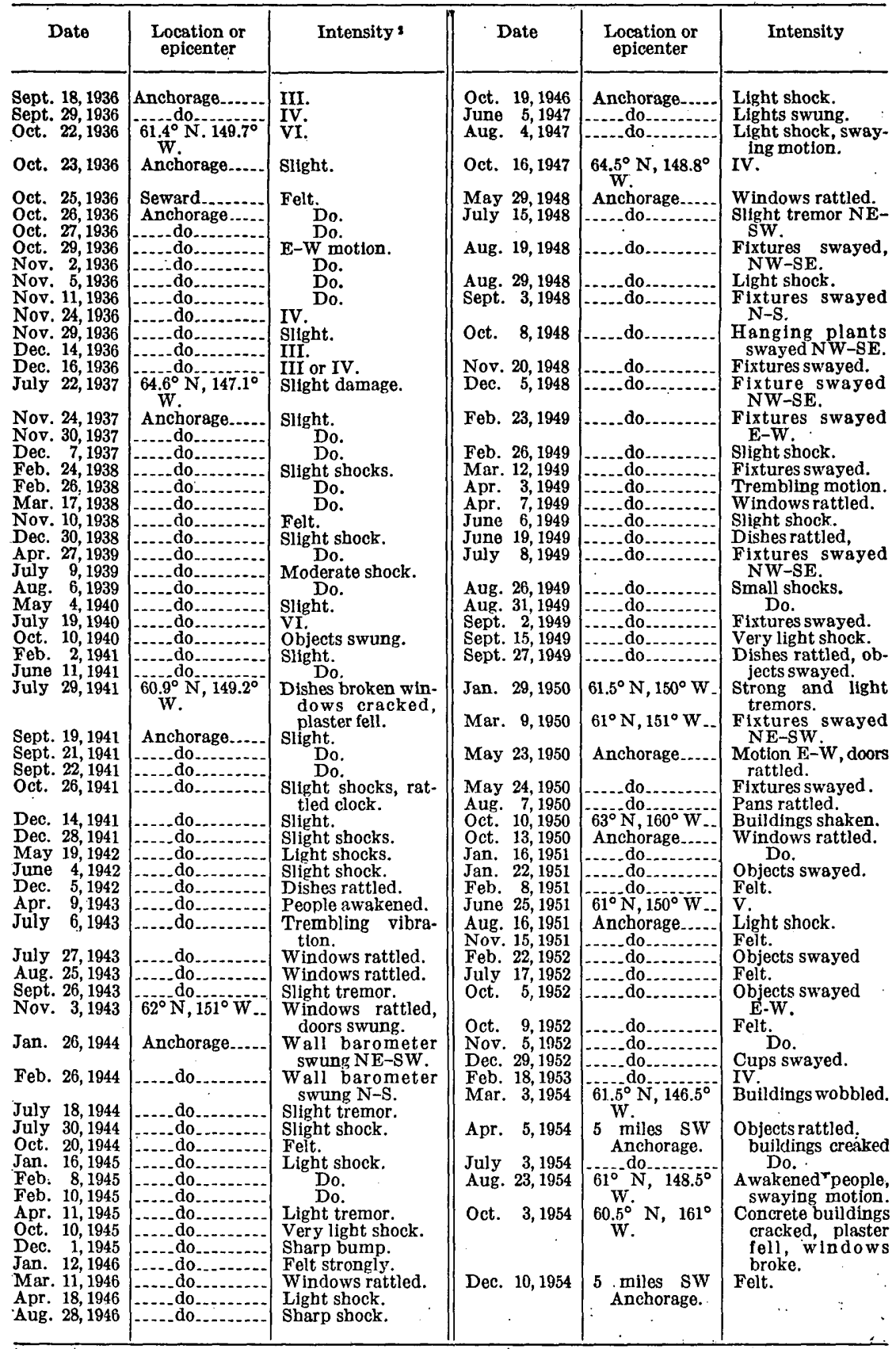

1 Data collected from the Coast and Geodetic Survey series of United States Earthquakes, the years 1936-54.

2 Numerical ratings are Modified Mercalli Scale intensities. 
Within Anchorage, slumps and slope failures along Fifteenth Street between $\mathrm{K}$. and $\mathrm{L}^{10}$ caused a retaining wall to fail owing to the weight of the material moving outward from an oversteepened slope. Another contributing factor here could have been the presence of Bootlegger Cove clay along the south bluff of Ship Creek. The clay may have acted as a barrier to water movement and saturated the lower part of the sand and gravel as well as the upper part of the clay.

\section{DRAINAGE}

No tests were made to determine permeability or drainage characteristics of the glacial deposits, but certain generalities can be drawn from field observations.

The stratified drift is permeable in most places, although any silt content reduces the permeability to some extent. Silty till, the Bootlegger Cove clay, and the windblown silt are most consistently impermeable in the Anchorage area. These deposits block the downward migration of water and can deflect the movement laterally along the surface, as in the case of the Bootlegger Cove clay, or can maintain a high water table and cause ponds or swamps to form in depressions, as is common on the surface of the ground moraine.

The use of drains in connection with the lateral movement of water along the upper surface of the Bootlegger Cove clay, has been suggested as a remedy for slumps and flows. One of the most common drainage problems in the area, however, involves swamps and muskegs. Because of the vegetative growth in the muskegs and lack of lateral water movement through the peat, deep and widely separated ditches will not prove completely satisfactory. DachnowskiStokes (1941, p. 77) describes drainage ditches that have been successfully used in muskegs.

A good drainage outlet and shallow open ditches used as mains and laterals or cross drains are preferable to a few deep ones, since the effects of a drain extend only a short distance from the walls of the ditch. *** The distance between parallel lines of ditches depends on rainfall and on the type and texture of peat materials, the thickness and nature of the underlying peat layers, and the bottom relief of the mineral substratum. Peat areas with a convex or raised surface and those with a sloping surface can be drained as deep as the fibrous layers are found. Flat and valley deposits, however, which lie in water basins, can be drained only at great expense.

The deepening of the ditches from year to year will clean out any slump, and lower the level of the water table so that the peat will settle as the muskeg is drained.

Care should be taken in till areas during construction of roads. Between the coarse-grained subbase and the silty till, water can

10 Anchorage Daily Times, September 6, 1955. 
accumulate and may result in breaking of the surface as the moisture freezes and thaws with the change in seasons. Backfilling and installation of subdrains may alleviate problems where cuts are required in silty till.

\section{FROST HEA VE}

Seasonal frost action is detrimental where abrupt differential heaving takes place. The upward displacement is caused by the growth and accumulation of ice crystals into lenses or layers of ice. Homogeneous frozen soil, in which the water is frozen within the natural spaces and voids with no visible ice segregation, does not normally have upward displacement. Stratified or nonhomogeneous frozen soils, in which ice segregations visibly occupy spaces greater in size than the original voids, cause heaving of the surface (Johnson, 1952, p. 8 ). The actual process by which the ice accumulates in lenses is not agreed upon by all authors, but Taber (1929, p. 460) demonstrated, in part by the use of materials that freeze with a decrease in volume (benzine and nitrobenzine), that frost heaving was caused by pressure which he attributes to growth of ice layers. He also states $(1929$, p. 458$)$ that molecular cohesion is responsible for the uplift of the water through the capillary passages and its concentration in ice layers. In 1953 he restated these views. Other workers (Ruckli, Robert, 1950; Jumikis, 1954; and Winterkorn, 1947, 1954) applied the concepts of "thermo-osmosis" and suction force in soils to cause an upward flow of soil moisture and accumulation in lenses.

Studies over the years have shown that the deposits potentially dangerous with regard to frost-heaving are those with small particle sizes, such as fine sands, silty sands, or silty clays (Burton and Benkelman, 1931, p. 262; Morton, Tremper, Stokstad, and Casagrande, 1938, p. 356; Johnson, 1952, p. 108 referring to Watkins and Aarons, 1931, Otis, 1952, p. 272; Stokstad, 1952, p. 278). As a result, different workers have attempted to delimit by particle size materials susceptible to frost-heaving from materials nonsusceptible to frost-heaving. Casagrande $(1931$, p. 169) in a discussion that followed the 1932 paper by Benkelman and Olmstead made early mention of the role particle size plays in frost-heaving when he referred to a report by the Massachusetts Institute of Technology in which it was stated that ice segregation should be expected in-

* * * nonuniform soils containing more than three percent of grains smaller than $0.02 \mathrm{~mm}$., and in very uniform soils containing more than ten percent smaller than $0.02 \mathrm{~mm}$.

The Corps of Engineers Manual (1951, in Johnson, 1952, p. 170) agrees with Casagrande that inorganic materials containing 3 per- 
cent or more of grains finer than $0.02 \mathrm{~mm}$ in diameter by weight are considered frost-susceptible. Ruckli (1955, p. 656-5 to 656-6) modifies this classification as follows:

Tests performed in Zïrich and elsewhere have shown that it is not possible to trace an exact limit between frost-heaving and non-frost-heaving soils or aggregates merely on a granulometric basis. Soils, even those which satisfy the famous criterion by $\mathrm{A}$. Casagrande, can, under favorable conditions, show ice segregation. *** The experience of many years indicates that well-graded aggregates containing more than $3 \%$ of particles finer than $0.02 \mathrm{~mm}$ do not cause damage to roads by frost, regardless of the fact that the subsoil and the climatic conditions were favorable for the formation of ice lenses. This leads one to consider not only the technological composition of the aggregates but also the hydrological and geotechnical condition of the site in question.

Johnson (1952, p. 171) refers to a list in which the seasonal frostsusceptible soils are classified into four groups, in order of their increasing susceptibility. Certain of the deposits in the Anchorage area are placed opposite the groups in which they fall as determined from the percentage of the small-particle size. Although this classification does not take into account Ruckli's hydrological and geotechnical conditions, the classification is suitable for the purposes of this report. (See table 7.)

Table 7.-Relative susceptibility of geologic units in the Anchorage area to fros action

\begin{tabular}{|c|c|c|}
\hline Oroup 1 & Description 2 & Critical geologic units in part or entirety \\
\hline F1 & $\begin{array}{l}\text { Gravelly soils containing between } 3 \text { and } 20 \\
\text { percent of material finer than } 0.02 \mathrm{~mm} \\
\text { by weight. }\end{array}$ & $\begin{array}{l}\text { Local parts of Naptowne kame terraces and } \\
\text { kame fields; locally till of Knik ground. } \\
\text { moraine, till of Naptowne ground } \\
\text { moraine; part of Naptowne pitted out- } \\
\text { wash. }\end{array}$ \\
\hline F2 & $\begin{array}{l}\text { Sands containing between } 3 \text { and } 15 \text { percent } \\
\text { of material finer than } 0.02 \mathrm{~mm} \text { by weight. }\end{array}$ & $\begin{array}{l}\text { Dune sand, locally glaciofluvial ice-contact } \\
\text { deposits; local part of Knik pitted out- } \\
\text { wash; local parts of Naptowne outwash. }\end{array}$ \\
\hline F3 & $\begin{array}{l}\text { (a) Gravelly soils containing more than } 20 \\
\text { percent of material finer than } 0.02 \mathrm{~mm} \\
\text { by weight and sands, except fine silty } \\
\text { sands, containing more than } 15 \text { percent } \\
\text { of material finer than } 0.02 \mathrm{~mm} \text { by weight. } \\
\text { (b) Clays with plasticity indexes of } \\
\text { more than } 12 \text {, except varved clays. }\end{array}$ & $\begin{array}{l}\text { Till of Knik ground moraine, till of Nap- } \\
\text { towne ground moraine, local glacionluvial } \\
\text { ice-contact deposits; parts of prodelta } \\
\text { deposits. }\end{array}$ \\
\hline F4 & $\begin{array}{l}\text { (a) All silts including sandy silts. (b) } \\
\text { Fine silty sands containing more than } 15 \\
\text { percent of material finer than } 0.02 \mathrm{~mm} \\
\text { by weight. (c) Lean clays with plas- } \\
\text { ticity indexes of less than } 12 \text {. (d) } \\
\text { Vavred clays.s. }\end{array}$ & $\begin{array}{l}\text { Windblown sllt, unmapped surface loess, } \\
\text { parts of delta, Bootlegger Cove clay. }\end{array}$ \\
\hline
\end{tabular}

1 Listed in order of increasing susceptibility.

After Johnson (1952, p. 171) from Corps of Engineers Manual (1951).

"Varved clays may combine the undesirable properties of silts and soft clays; varved clays are likely to soften more readily than homogeneous clays with equal average water contents. 
Detrimental effects from frost-heaving occur where abrupt differential heaving takes place. Dependent upon the soil texture, moisture in the soil, and depth to ground water, all of which are variable, the frost heaves are uniform in types or effects. Damage to roads takes place in two ways; by actual heave, which can permanently fracture the pavement, or by the secondary effect of softening the roadbed and reducing the load-carrying capacity. Cracks in pavements, raised or tilted pavement slabs, breaking of pavement edges, reduction in load-carrying capacity, flowage of the saturated material with the resultant removal of support or the sliding of slopes are characteristics of frost heaves and frost boils. Explaining certain failures of pavements, Watkins (1945, p. 302) states that thawing progresses downward so that saturated silt overlies a frozen layer. The silt is not stable and gives away or flows beneath a flexible surface, and under light loads. If the saturated silt is "worked" by traffic, a free-flowing mud forms frost boils that are forced out along edges of pavements or through the riding surface.

Concrete pavements fracture or heave owing to frost action in the winter months when the ground is frozen. Skelton (1940, p. 464) considers the critical period for a concrete pavement to be when the subgrade and pavement are frozen solidly together. Any differential heaving will fracture the pavement. Though heaves in the flexible pavement can be severe, and take place in the winter, the greatest break-up of flexible pavements takes place during the spring thaw when the load carrying capacity of the subgrade is low (Johnson, 1952, p. 4).

In a study of locations of heaves, Burton and Benkelman (1931, p. 263) reported that of 500 heaves, 76 percent were in cuts, 10 percent were in fills, and 14 percent were in the transition zone between cuts and fills. Of 141 heaves in the cuts, 80 percent were in cuts 4 or more feet deep. This seems to indicate that materials in cuts need to be examined carefully. Heaves or frost boils seen by the authors in the Anchorage area were in cuts or on the edge of cuts in the glacial silt or silty till of ground moraine.

Methods of preventing frost heaving and the resulting damage are discussed by many workers (Burton and Benkelman, 1931; Benkelman and Olmstead, 1932; Beskow, Gunnar, 1938; Morton, Tremper, Stokstad, and Casagrande, 1938; Winn, 1940; and many others), as well as in "Frost Action in Soils, a Symposium" by K. B. Woods, Chairman, Highway Research Board (1952, spec. rept. no. 2). In his review of the literature Johnson (1952, p. 159-216) compiled the most used design methods for preventing or alleviating detrimental frost action, and the various construction practices relative to frost action. Some of the common design practices included change in 
road location, change in grade elevation, subsurface drainage, excavation and replacement-in some places with drains-and the use of insulation. Attempts to counteract frost action include the use of soluble admixtures, such as calcium chloride, sodium chloride, sulfuric acid, sulfite liquors, resinous materials, sodium silicate, and liquid binders such as road oils and tar.

In order to prevent frost heaving in fine-grained materials that contain capillary water, which can not be drained by artificial methods, it is necessary to remove these materials and replace them with materials having good drainage. Coarser materials are improved by merely installing properly designed drainage systems (Benkelman and Olmstead, 1932, p. 162). Table 5 shows what surficial units in the Anchorage area should be considered potentially susceptible to frost-heaving.

Well logs cited in text (Cederstrom and Turner, 1959)

\begin{tabular}{c|c|c}
\hline Description & $\begin{array}{c}\text { Thickness } \\
\text { (feet) }\end{array}$ & $\begin{array}{c}\text { Depth } \\
\text { (feet) }\end{array}$ \\
\hline
\end{tabular}

Well 17, Chester Creek and Spenard Road; Muellers Kennels

Altitude, 18 feet

Top soll and gravel._.
Sand.
Gray clay and gravel
Till
Gravel; water...

Well 26, C St. and Fircweed Lane; Nat Smith

Altitude, 104 feet

\begin{tabular}{l}
\hline Band and gravel_... \\
Brown sticky clay \\
Gravel. \\
Brown clay.
\end{tabular}

Well 28, Fireweed Lane; Spenard Public School

Altitude, 100 feet

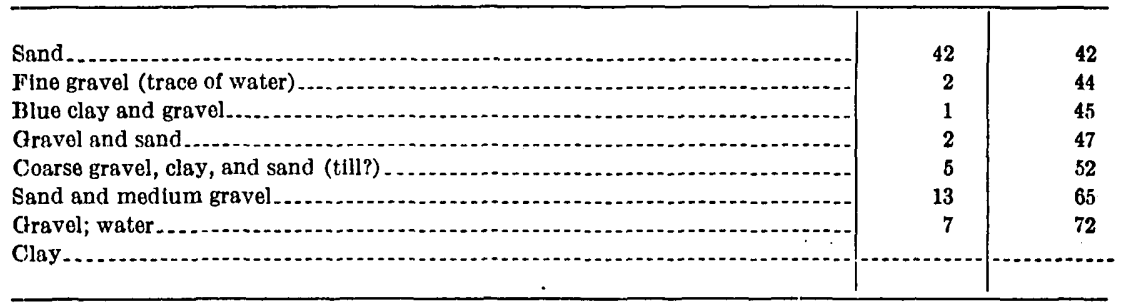


Well logs cited in text-Continued

\begin{tabular}{r|c|c}
\hline Description & $\begin{array}{c}\text { Thickness } \\
\text { (feet) }\end{array}$ & $\begin{array}{c}\text { Depth } \\
\text { (feet) }\end{array}$ \\
\hline
\end{tabular}

Well 29, Fireweed Lane; Federal Bureau of Investigation

Altitude, 100 feet

Sand. $\quad . . \ldots$
Clean coarse gravel

Well 33, Fireweed Lane, near Spenard Road; B. Irvin

Altitude, 99 feet

Sand and gravel.
Blue clay and gravel (till?)
Lonse gravel.

Well 34, Spenard Road; Romig Park Subdivision

Altitude, 102 feet

Sand and fine gravel

Blue clay.

Black sand and gravel

Coal.

Sand and fine gravel

19
61
72
75
79

Well 46, Spenard Road, near KFQD Road; Piggiy Wiggly Store

Altitude, 100 feet

\begin{tabular}{|c|c|c|}
\hline Sand . . . & 35 & 35 \\
\hline Blue clay and gravel & 8 & 43 \\
\hline Quicksand .............. & 12 & 55 \\
\hline Blue clay & 4 & 59 \\
\hline Quicksand. & 10 & 69 \\
\hline Blue clay & 8 & 77 \\
\hline Gravelly sand; some water . . . & 2 & 79 \\
\hline Record missing & 9 & 88 \\
\hline Coarse sand and gravel....... & 2 & 90 \\
\hline Till & 30 & 120 \\
\hline Gravel; some water..................... & 1 & 121 \\
\hline Till & 6 & 127 \\
\hline Gravel; water. & 1 & 128 \\
\hline
\end{tabular}


Well logs cited in text-Continued

\begin{tabular}{c|c|c}
\hline Description & $\begin{array}{c}\text { Thickness } \\
\text { (feet) }\end{array}$ & $\begin{array}{c}\text { Depth } \\
\text { (feet) }\end{array}$ \\
\hline
\end{tabular}

Well 48, KFQD Road, nearAlaska Railroad; La Honda Trailer Court

Altitude, 56 feet

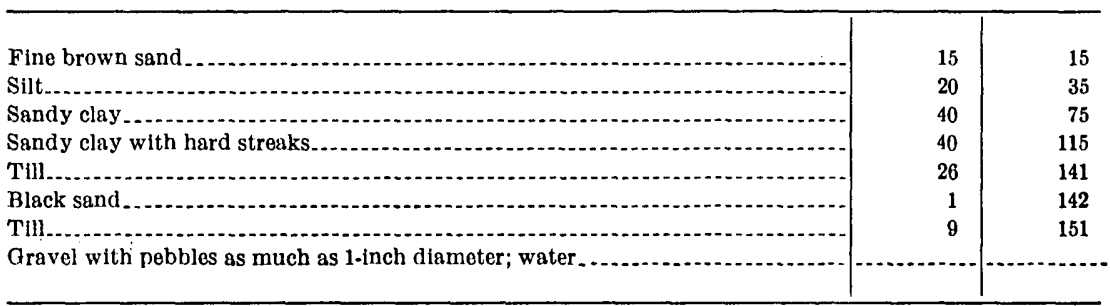

Well 50, Turnagain Heights; R. Atwood

Altitude, 74 feet

\begin{tabular}{|c|c|c|}
\hline Sand. & 8 & 8 \\
\hline Sand and gravel.... & 15 & 23 \\
\hline Conl. & 1 & 24 \\
\hline Blue clay ..... & 117 & 141 \\
\hline Sand and gravel & 6 & 147 \\
\hline Blue clay.... & 3 & 150 \\
\hline
\end{tabular}

Well 69, Spenard and McRae Roads; Trailer Roost

Altitude, 89 feet

\begin{tabular}{|c|c|c|}
\hline Top soll and clay & 4 & 4 \\
\hline Gravel and clay & 12 & 16 \\
\hline Brown sandy clay........ & 16 & 32 \\
\hline Gray sand; some water. . . . . . . & 25 & 57 \\
\hline 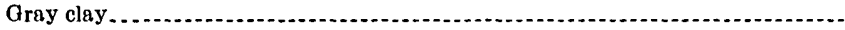 & 24 & 81 \\
\hline Gray silt.................. & 13 & 94 \\
\hline Gray clay................. & 7 & 101 \\
\hline Small gravel; dry $\ldots . . . .$. & 2 & 103 \\
\hline 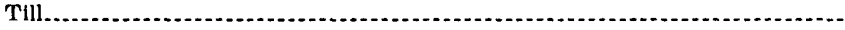 & 31 & 134 \\
\hline Gray silt & 4 & 138 \\
\hline Till..... & 12 & 150 \\
\hline Sand and gravel & 2 & 152 \\
\hline
\end{tabular}

Well 73, McRae Road, west of Fish Creek; Tope Construction Co.

Altitude, 59 feet

\begin{tabular}{|c|c|c|}
\hline Brown sand & 15 & 15 \\
\hline Soft blue clay, no stones, with thin layer of sand at base...- & 45 & 60 \\
\hline Soft blue clay with stones............. & 34 & 94 \\
\hline Heaving fine gray sand......... & 45 & 139 \\
\hline Coal. & 1 & 140 \\
\hline Sand . . . . . & 8 & 148 \\
\hline Sand and gravel; water. & 17 & 165 \\
\hline Blue silty clay & 23 & 188 \\
\hline 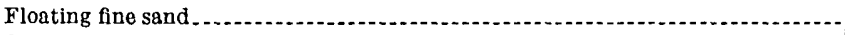 & 5 & 193 \\
\hline Coal and sand.... & 6 & 199 \\
\hline Fine gray sand ... & 25 & 224 \\
\hline Blue clay.... & 4 & 228 \\
\hline Fine sand.. $.2 n$ & 7 & 235 \\
\hline Clay . . . . & 1 & 236 \\
\hline Pebbly sand; water & 2 & \\
\hline
\end{tabular}




\section{SURFICIAL GEOLOGY OF ANCHORAGE AND VICINITY, ALASKA}

Well logs cited in text-Continued

\begin{tabular}{r|c|c}
\hline Description & $\begin{array}{c}\text { Thickness } \\
\text { (feet) }\end{array}$ & $\begin{array}{c}\text { Depth } \\
\text { (feet) }\end{array}$ \\
\hline
\end{tabular}

Well 78, Spenard Road, west of Fish Creek; Grizzly Trailer Court

Altitude, 64 feet

\begin{tabular}{|c|c|c|}
\hline 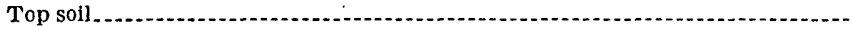 & 2 & 2 \\
\hline Gray sand & 16 & 18 \\
\hline Gray clay & 14 & 32 \\
\hline 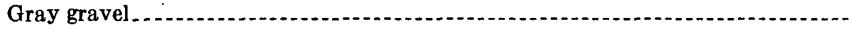 & 9 & 41 \\
\hline Gray clay & 4 & 45 \\
\hline Heaving sand; water & 6 & 51 \\
\hline 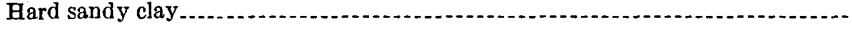 & 4 & 55 \\
\hline Heaving sand; water & 24 & 79 \\
\hline Gray clay..................... & . 2 & 81 \\
\hline Gravel and sand; water & 2 & 83 \\
\hline
\end{tabular}

Well 80, at road forks east of Lake Spenard; Lake Motel

Altitude, 72 fcet

Yellow sand.
Soft gray silty clay
Tough gray clay
Gray silt.
Gray clay. .
Dark gravel, ranging in size from small grains up to pebbles 2 inches in diameter.
About 75 percent of gravel is larger than one half inch diameter. Water...

Well 81, near east shore of Lake Spenard; W. W. Fultz

Altitude, 67 feet

\begin{tabular}{|c|c|c|}
\hline$:$ & & \\
\hline Sand ............................... & . . 35 & 35 \\
\hline Gray clay & 17 & 52 \\
\hline Hardpan . . & 13 & 65 \\
\hline Coarse gravel with pebbles as much as 2 inches in diameter; water................. & 2 & 67 \\
\hline
\end{tabular}

Well 83, Southeast shore of Lake Hood; 10th Sea and Air Rescue Base

Altitude, 72 feet

\begin{tabular}{|c|c|c|}
\hline Sand & 24 & .24 \\
\hline Glacial silt . . . . & 23 & 47 \\
\hline Quicksand..- & 11 & 58 \\
\hline Glacial silt. . . & .93 & 151 \\
\hline 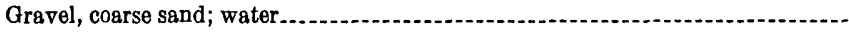 & 11 & 162 \\
\hline
\end{tabular}




\section{Well logs cited in text-Continued}

\begin{tabular}{c|c|c}
\hline Description & $\begin{array}{c}\text { Thickness } \\
\text { (feet) }\end{array}$ & $\begin{array}{c}\text { Depth } \\
\text { (feet) }\end{array}$ \\
\hline
\end{tabular}

Well 86, Terminal Building; International Alrport

Altitude, 88 feet

\begin{tabular}{|c|c|c|}
\hline Silt_._. & 10 & 10 \\
\hline 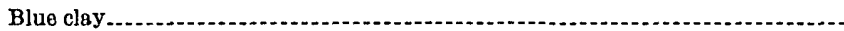 & 10 & 20 \\
\hline Sandy silt. & 10 & 30 \\
\hline Coarse sand . . . . & 10 & 40 \\
\hline 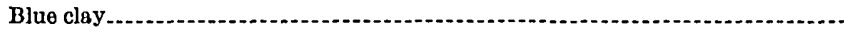 & 20 & 60 \\
\hline 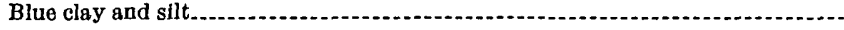 & 60 & 120 \\
\hline Fine sand & 20 & 140 \\
\hline Blue clay & 60 & 200 \\
\hline 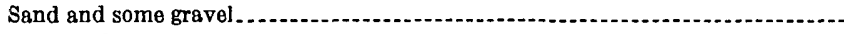 & 5 & $\cdot \quad 205$ \\
\hline Fine sand; water $\ldots$ & 85 & 290 \\
\hline Medium coarse sand; water bearing & 18 & 308 \\
\hline
\end{tabular}

Well 88, International Airport and Sand Lake Roads; International Trailer Park

Altitude, 76 feet

Sand and gravel.

Blue-gray clay and silt, with occasional stones.

Hard layer.

Gravel; water .

Well 90, Sand Lake Road, east of De Long Lake; Doyle Clover,

Altitude, 100 feet

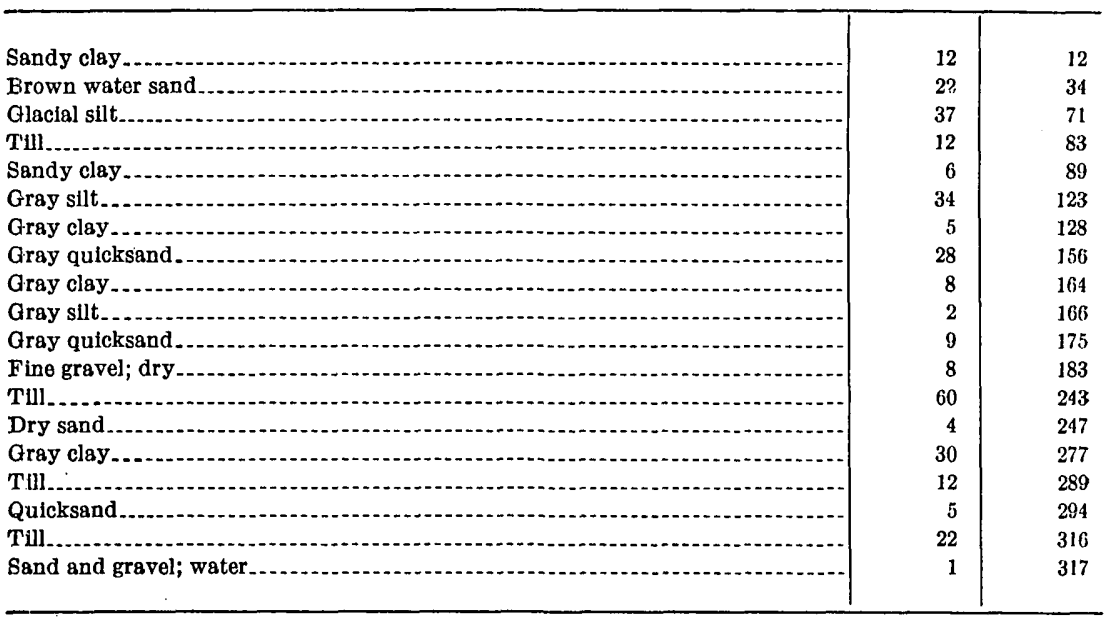


116 SURFICIAL GEOLOGY OF ANCHORAGE AND VICINITY, ALASKA

Well logs cited in text-Continued

\begin{tabular}{c|c|c}
\hline Description & $\begin{array}{c}\text { Thickness } \\
\text { (feet) }\end{array}$ & $\begin{array}{c}\text { Depth } \\
\text { (feet) }\end{array}$ \\
\hline
\end{tabular}

Well 93, Northeast shore of Sand Lake; Ellis Crawford

Altitude, 106 feet

\begin{tabular}{|c|c|c|}
\hline Sandy brown clay & 32 & 32 \\
\hline Blue clay .......... & 24 & 56 \\
\hline Gravel and clay (till?) ... & 3 & 59 \\
\hline Blue clay & 11 & 70 \\
\hline Sand and silt & 48 & 118 \\
\hline Quicksand & 11 & 129 \\
\hline Gray clay $\ldots \ldots \ldots$ & 7 & 136 \\
\hline Running silt and sand... & 61 & 197 \\
\hline Hard clay and gravel (till?).. & 92 & 289 \\
\hline Sand . . . . . & 7 & 296 \\
\hline Hard clay and gravel (till?) & 19 & 315 \\
\hline Gravel; water & 1 & 316 \\
\hline Sandy gravel; water & 2 & 318 \\
\hline
\end{tabular}

Well 97, Two and three-fourths mile southwest of Lake Spenard; (West Raspberry Road, extended); Alaska Communications System

Altitude, 140 feet

Yellow clayey sand.

Gravel and clay (till?)

Yellow clay and gravel (till)

Semiconsolidated sand with coal granules

Hard yellow sand.

Yellow sand with coal.

Yellow clay with coal streaks.

Sand with some clay.

Sandy gravel.

Sandy with coal...

Sandy gravel; a little water.

Gravel hardpan (till)

Fine sand.

Sand and gravel; a little water

Hard packed sandy gravel; a little water

Sand and gravel.

Gray clay with small gravel (till?)

Hark packed fine sand.

Gray clay with gravel (till?)

Green sand; a little water.

Tough clay

Sand; a little water.

Clay -

Gravel and sand.

Small gravel.

Hard gravel and green sand; a little water

Clayey till.

Gravelly till; a little water

Hard clay and gravel with clay (till?)

Small gravel; yields about 5 g.p.m.

Coarse gravel with cobbles.

Cemented gravel, "rock-like" (till?)

Coarse water gravel. 
Well logs cited in text-Continued

\begin{tabular}{c|c|c}
\hline Description & $\begin{array}{c}\text { Thickness } \\
\text { (feet) }\end{array}$ & $\begin{array}{c}\text { Depth } \\
\text { (feet) }\end{array}$ \\
\hline
\end{tabular}

Well 101, North Jewel Lake Road, near west Strawberry Road; I. Evenson

Altitude, 104 feet

Blue clay $\begin{aligned} & \text { Medium sand. } \\ & \text { Coarse sand. }\end{aligned}$.
Very coarse sand
Gravel; water

Well 173, Oil well Road of the Palmer High way at U.S. Army Fire Control Station; U.S. Geological Survey Test Well 8

Altitude, 200 feet

\begin{tabular}{|c|c|c|}
\hline Soil. & 3 & 3 \\
\hline Gravel & 15 & 18 \\
\hline Bouldery gravel & 27 & 45 \\
\hline Clay & 2 & 47 \\
\hline 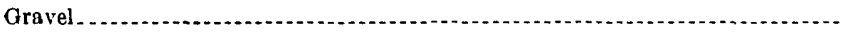 & 11 & 58 \\
\hline Till & 28 & 86 \\
\hline 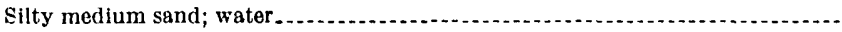 & 12 & 98 \\
\hline Soft till & 11 & 109 \\
\hline Sand; water & 2 & 111 \\
\hline Hard till. . . . & 8 & 119 \\
\hline Gray clay & 4 & 123 \\
\hline Fine to medium sand; water & 16 & 139 \\
\hline Hard till & 14 & 153 \\
\hline Silty medium to coarse sand & 13 & 166 \\
\hline $\begin{array}{l}\text { Harder medium to coarse sand pumped } 6 \mathrm{hrs} \text {. from open end hole at } 70 \mathrm{~g} . \mathrm{p} . \mathrm{m} \text {. } \\
\text { with } 18 \mathrm{ft} \text {. of drawdown. Static } 81 / 2 \mathrm{ft} \text {. below surface. }\end{array}$ & 9 & 175 \\
\hline Coarse sandy gravel. Short baller test yielded 14 g.p.m. with $50 \mathrm{ft}$. of drawdown - & 6 & 181 \\
\hline Brown till (?) & 33 & 214 \\
\hline $\begin{array}{l}\text { Gray till, very hard. Short pumping test yiolded } 30 \text { g.p.m. with } 9 \mathrm{ft} \text {. of draw- } \\
\text { down. Water comes from sandy streaks in interval between } 217 \text { and } 247 \mathrm{ft} \text {...- }\end{array}$ & 38 & 252 \\
\hline Brown till, very hard & 96 & 348 \\
\hline Sticky gray clay & 22 & 370 \\
\hline Coal layers in clay & 5 & 375 \\
\hline Sticky gray clay & 15 & 390 \\
\hline Hard sandy clay & 2 & 392 \\
\hline Sand & 2 & 394 \\
\hline Gray sandy clay. Bottom of casing at $397 \mathrm{ft}$ & 53 & 447 \\
\hline $\begin{array}{l}\text { Brown shale with coal streaks and organic matter. In an } 8 \text { hour pumping test } \\
\text { ylulded } 42 \mathrm{~g} . \text { p. m. with } 17 \mathrm{ft} \text {. of drawdown. Static level is } 75 \mathrm{ft} \text {. below surface... }\end{array}$ & 63 & 510 \\
\hline $\begin{array}{l}\text { Gray to black shale with some coal streaks; black shale contains much organic } \\
\text { matter; sticky when wet. } 1 \mathrm{ft} \text {. layer of friable fine-grained green sandstone at } \\
555 \mathrm{ft} . . . . . .\end{array}$ & 92 & 602 \\
\hline Fairly hard gray flne- to medium-grained sandstone & 7 & 609 \\
\hline $\begin{array}{l}\text { Gray to black shale, as in interval from } 510 \text { to } 602 \mathrm{ft} \text {. Pumping test at } 617 \mathrm{ft} \text {. } \\
\text { yielded } 42 \mathrm{~g} . \mathrm{p} . \mathrm{m} \text {. with } 12 \mathrm{ft} \text {. of drawdown at end of } 6 \text { hours' pumping; static } \\
\text { lovel is } 75 \mathrm{ft} \text {. below surface..... }\end{array}$ & 8 & 617 \\
\hline
\end{tabular}




\section{SURFICIAL GEOLOGY OF ANCHORAGE AND VICINITY, ALASKA}

\section{U.S. Corps of Engineers, Well Logs 12}

\begin{tabular}{c|c|c}
\hline Description & $\begin{array}{c}\text { Thickness } \\
\text { (feet) }\end{array}$ & $\begin{array}{c}\text { Depth } \\
\text { (feet) }\end{array}$ \\
\hline
\end{tabular}

Campbell Point ACS Receiver Station, Drilled July 1-18 1952, by J. C. Merrington, Sec. 33 , T. 13 N., R. 4 W.

Altitude 142 feet

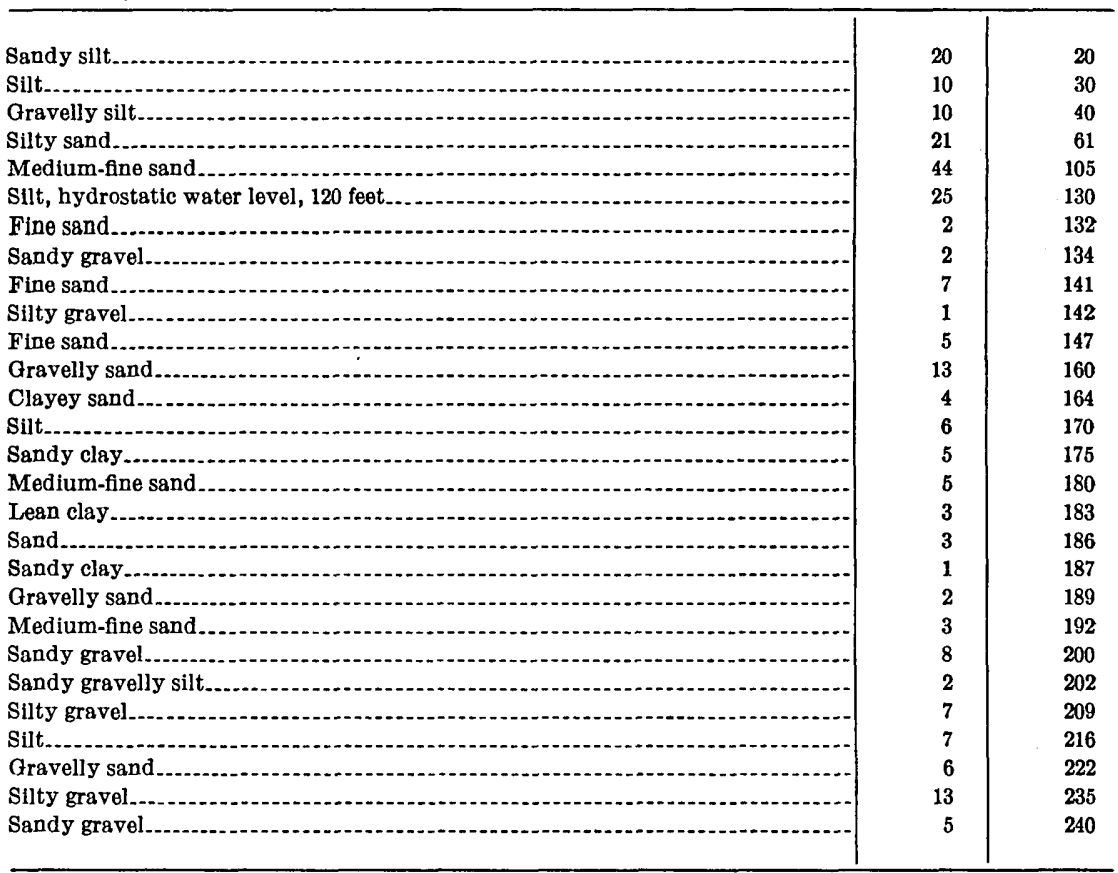

1 By permission of the District Engineer, U.S. Corps of Engineers, Alaska District.

2 Descriptive logs converted from graphic logs by the authors. 
U.S. Corps of Engineers, Well Logs-Continued

\begin{tabular}{r|c|c}
\hline$\cdot$ Description & $\begin{array}{c}\text { Thickness } \\
\text { (feet) }\end{array}$ & $\begin{array}{c}\text { Depth } \\
\text { (feet) }\end{array}$ \\
\hline
\end{tabular}

West Power Plant Well, Elmendorf Air Force Base, Drilled by McInroy and C. P. Lewis, SE 14 sec. 8, T. 13 N., R. 3 W. (N 107,076-E 105,078)

Altitude 140.05 feet

\begin{tabular}{|c|c|c|}
\hline Gravelly sand... & 13. 5 & 13.5 \\
\hline Sandy gravel.... & 11.5 & 25.0 \\
\hline Gravelly sand.... & 28 & 53 \\
\hline Medium sand.................. & 4 & 57 \\
\hline Gray clay... & 130 & 187 \\
\hline Quicksand....... & 4 & 191 \\
\hline Gray clay & 17 & 208 \\
\hline Gravelly sand. & 15 & 223 \\
\hline Hard till with sand streaks......... & 13 & 236 \\
\hline Soft sticky clay................... & 26 & 262 \\
\hline Blue estuarine clay..... & 39 & 301 \\
\hline Gravel hardpan. & 2.5 & 303.5 \\
\hline 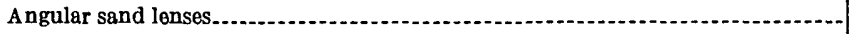 & 2.5 & 306 \\
\hline Sand grading into clay size & 5.5 & 311.5 \\
\hline Sand grades from coarse to fine, coarse gravel with Crustacean fragments. & 11 & 322.5 \\
\hline 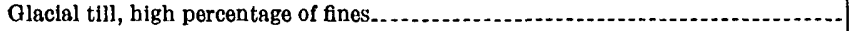 & 17.5 & 340 \\
\hline Hard cementlike clayey till. & 2.5 & 342.5 \\
\hline 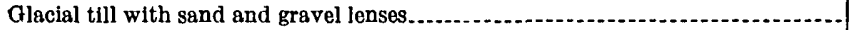 & 108.5 & 451 \\
\hline 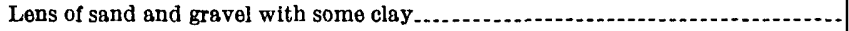 & 8 & 459 \\
\hline $\begin{array}{l}\text { Glacial till consisting of tan clay and silt with subrounded pebbles and rocks, } \\
\text { several thin lenses of sand and gravel were encountered but no water........... }\end{array}$ & 81 & 540 \\
\hline Gray silt and clay with some pebbles. & 40 & 580 \\
\hline Gray sillt, no rocks or pebbles, pieces of coal at about 610 and 645 feet.............. & 92.5 & 672.5 \\
\hline 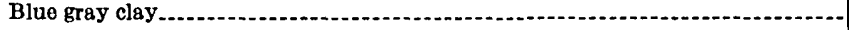 & 11 & 683.5 \\
\hline 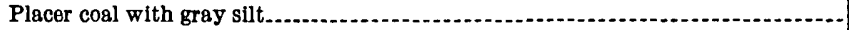 & 12.5 & 696 \\
\hline Gray sand clay & 7 & 703 \\
\hline Hard sandy clay (shale?) & 63 & 766 \\
\hline Contact between Quaternary and Tertiary (tentative) & 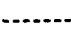 & 766 \\
\hline 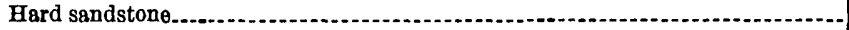 & 12 & 778 \\
\hline Thin beds of coal and shale with a few beds of sandstone & 72 & 850 \\
\hline
\end{tabular}


U.S. Corps of Engineers, Well Logs-Continued

\begin{tabular}{c|c|c}
\hline Description & $\begin{array}{c}\text { Thickness } \\
\text { (feet) }\end{array}$ & $\begin{array}{c}\text { Depth } \\
\text { (feet) }\end{array}$ \\
\hline
\end{tabular}

International Airport, Anchorage, National Guard Facilities Water Well, Drilled April 1954 by McInroy Drilling Co., NW1/4 sec. 3, T. 12 N., R. 4 W. (N 83,252-E 81,666)

Altitu de 106.2 feet

\begin{tabular}{|c|c|c|}
\hline Silt, some organic material, small amount of sand & 13.5 & 13.5 \\
\hline Gravelly, silty sand. & 3.5 & 17 \\
\hline 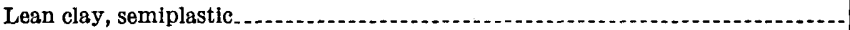 & 28 & 45 \\
\hline Fine sand & 5 & 50 \\
\hline Silty sand with placer coal; static water level, 79 feet.... & 40 & 90 \\
\hline Sillt. & 7 & 97 \\
\hline Fine sand, occasional fragments of coal... & 17 & $11 \dot{x}$ \\
\hline Medium to fine sand, 11 percent gravel...... & 4 & 115 \\
\hline Silty sand & 12 & 130 \\
\hline 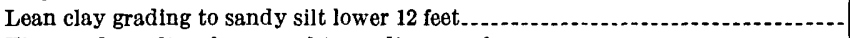 & 34 & 164 \\
\hline 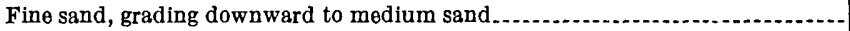 & 12 & 176 \\
\hline Gravel & 2 & 178 \\
\hline Gravelly sand & 2 & 180 \\
\hline Sandy gravel. & 5 & 185 \\
\hline 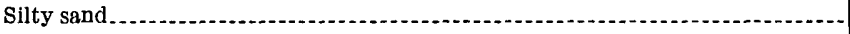 & 5 & 190 \\
\hline Silty sandy gravel, cemented tight.......- & 8 & 198 \\
\hline Sandy gravel (60 percent) & 6 & 204 \\
\hline Sand & 9 & 213 \\
\hline Gravelly sand (67 percent).... & 8 & 221 \\
\hline Sandy gravel (56 percent) $\ldots . . . .$. & 7 & 228 \\
\hline Gravelly sand (78 percent) & 3 & 231 \\
\hline Sandy gravel (64 percent) & 6 & 237 \\
\hline Gravelly sand (70 percent) & 4. 5 & 241.5 \\
\hline Sandy gravel (64 percent) & 5.5 & 247 \\
\hline Gravelly sand (74 percent) & 11 & 258 \\
\hline Sandy gravel (53 percent) & 5 & 263 \\
\hline Sand, medium to coarse (92 percent) $(0.8$ percent gravel) & 5 & 268 \\
\hline Sflty gravel, tight, impervious. & 2 & 270 \\
\hline
\end{tabular}

3 As used by the Corps of Engineers, the percentage is the amount of the principal material, or the percentage of the material that the figure immediately follows.

DH-3, Drilled Sept. and Oct. 1950 by J. P. March, NE1/4 sec. 6, T. 13 N, R. 2 W. (N 113,715-E 130,240)

\section{Altitude 298.6 feet}

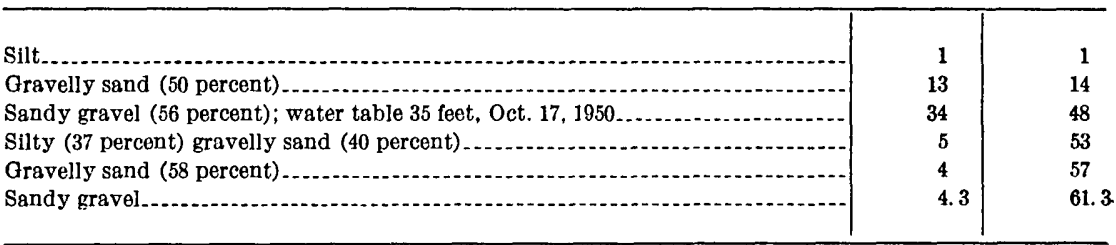


U.S. Corps of Engineers, Well Logs-Continued

\begin{tabular}{c|c|c}
\hline Description & $\begin{array}{c}\text { Thickness } \\
\text { (feet) }\end{array}$ & $\begin{array}{c}\text { Depth } \\
\text { (feet) }\end{array}$ \\
\hline
\end{tabular}

DH-4, Drilled Sept.-Oct. 1950, by J. P. March, NW $1 / 4$ sec. 6, T. 13 N., R. 2 W. (N 112,820-E 128,150)

\section{Altitude 280.5 feet}

Silt._ity (16 percent) gravelly sand (51 percent); top of perched water table 13 feet,
bottom 29 feet, Sept. 19, 1950.
Gravelly sand (52 percent)
Gravelly sandy silt (54 percent)
Gravelly sandy clay (63 percent)
Sandy gravel (54 percent)
Silty (18 percent) sandy gravel (42 percent); water table 45.5 feet, 0 ct. $6,1950 \ldots$
Gravelly sand (50 percent)
Silty (11 percent) sandy gravel (52 percent)
Sandy gravel (62 percent)

DH-7, Drilled Dec. 4-15, 1950, by J. P. March, NW1/4 sec. 7, T. 13 N., R. 3 W. (N 109,560-E 96,050) Altitude 15.0 feet

\begin{tabular}{|c|c|c|}
\hline 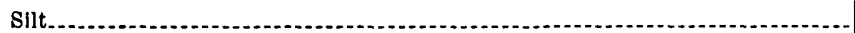 & 49 & \\
\hline Lean clay $(100$ percent) & 52.5 & 101.5 \\
\hline
\end{tabular}

DH-28, Drilled Sept.-Oct. 1952, by Chapman Drilling Co., NE14 sec. 9, T. 13 N., R. 3 W. (N 107, 270-E 107, 215)

Altitude 100 feet

Sendy gravel $\ldots \ldots \ldots$
Fine sand
Blue clay

DH-42, Drilled, March 27, 1953, NW1/4 sec. 7, T. 13 N., R. 3 W. (N 108,373-E 97,250)

Altitude 17.4 feet

Peat, muskeg; saturated $\ldots \ldots \ldots \ldots$
Lean clay, blue, stiff $\ldots \ldots$

DH-43, Drilled Nov. 3-13, 1953, by MeInroy Drilling Co., NW14 sec. 12, T. 13 N., R. 3 W. (N 108,630-E $120,410)$

Altitude 222.5 feet

Sandy gravel . .
Medium fine sand, occasional pebbles
Sandy gravel.


U.S. Corps of Engineers, Well Logs-Continued

\begin{tabular}{c|c|c}
\hline Description & $\begin{array}{c}\text { Thickness } \\
\text { (feet) }\end{array}$ & $\begin{array}{c}\text { Depth } \\
\text { (feet) }\end{array}$ \\
\hline
\end{tabular}

No. 55, Well No. 6, Drilled by Alaska District Engineers (no date available), NW14/4W 34, sec. 12, T. 13 N. R. 3 W.

Altitude approx. 248.0 feet

\begin{tabular}{|c|c|c|}
\hline "Till; probable high water level, 223.5 feet; probable low water level 216.5 feet. ... & 32.5 & 32. 5 \\
\hline Blue clay with dry gravel & 20.0 & 52.5 \\
\hline 'Till & 23.0 & 75.5 \\
\hline Till, impervious. & 41.5 & 117. 0 \\
\hline iSandy silty gravel. & 4.5 & 121.5 \\
\hline Gravelly sand $\ldots . . . . . . . .$. & 2.5 & 124.0 \\
\hline Silt layers in sand and gravel & 36.0 & 160.0 \\
\hline
\end{tabular}

No. 62, Well No. 3, Drilled by Alaska District Engineers (no date available), NE14 NW 34 sec. 12, T. 13 N., R. 3 W.

Altitude approx. 247.0 feet

\begin{tabular}{|c|c|c|}
\hline Fill... & 5.0 & 5. 0 \\
\hline Gravel & 5. 0 & 10.0 \\
\hline 'Till; probable high water level, 223.5 ; probable low water level, $216.5 \ldots .$. & 22.0 & 32.0 \\
\hline Blue clay with pebbles & 12. 0 & 44. 0 \\
\hline Coarse gravel & 2.0 & 46. 0 \\
\hline 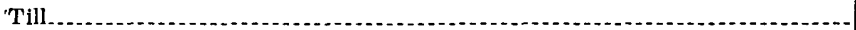 & 17.0 & 63. 0 \\
\hline Gravelly sand with clay & 45. 0 & 108.0 \\
\hline Blue clay with gravel & 8. 0 & 116. 0 \\
\hline Gravelly sand & 19. 0 & 135.0 \\
\hline Sand with occasional gravel & 10.0 & 145.0 \\
\hline
\end{tabular}

\section{REFERENCES CITED}

Benkelman, A. C., and Olmstead, F. R., 1932, A new theory of frost heaving: Highway Research Board Proc., v. 11, pt. 1, p. 152-165.

Beskow, Gunnar, 1938, Prevention of detrimental frost heave in Sweden; in Soil Mechanics and Soil Stabilization: Highway Research Board Proc., v. 18, pt. 2, p. 366-370.

Brooks, A. H., 1906, The geography and geology of Alaska, a summary of existing knowledge: U.S. Geol. Survey Prof. Paper 45, 327 p. [1907].

— 1923, A petroleum seepage near Anchorage: U.S. Geol. Survey Bull. 739, p. 133-135.

Buddington, A. F., 1927, Abandoned marine trenches in southeastern Alaska: Am. Jour. Sci., ser. 5, v. 13, p. 45-52.

Burton, V. R., and Benkelman, A. C., 1931, The relation of certain frost phenomena to the subgrade: Highway Research Board Proc., v. 10, p. 259275.

Byerly, Perry, 1942, Seismology : New York, Prentice-Hall, 256 p.

Capps, S. R., 1916, The Turnagain-Knik region: U.S. Geol. Survey Bull, 642, p. 147-194.

$\longrightarrow, 1940$, Geology of the Alaska Railroad Region: U.S. Geol. Survey Bull. 907, $201 \mathrm{p}$.

Casagrande, Arthur, 1931, Discussion of frost heaving: Highway Research Board Proc., v. 11, pt. 1, p. 168-172. 
Cederstrom, D. J.; 1952, Summary of ground-water development in Alaska, 1950 : U.S. Geol. Survey Circ. 169, 37 p.

Cederstrom, D. J., and Trainer, F. W., 1953, Tabulations of well records and logs and chemical analyses of ground waters in the vicinity of Anchorage, Alaska: U.S. Geol. Survey open file rept., 33 p.

City Planning Commission, 1955, July, Preliminary plan, water for Anchorage, $28 \mathrm{p}$.

Dachnowski-Stokes, A. P., 1941, Peat resources in Alaska : U.S. Dept. Agr. Tech. Bull. 769, 84 p.

Deevey, E. S., and Flint, R. F., 1957, Postglacial hypsithermal interval: Science, v. 125, no. 3240, p. 182-184.

Denny, C. S., 1936, Periglacial phenomena in southern Connecticut: Am. Jour. Scl., 5th ser., v. 32, no. 187, p. 322-342.

Dobrovolny, Ernest, and Miller, R. D., 1950, Descriptive geology of Anchorage and vicinity, Alaska : U.S. Geol. Survey open-file rept., 15 p.

Fardley, A. J., 1951, Structural geology of America : New York, Harper and Bros., $624 \mathrm{p}$.

Dmiliani, Cesare, 1955, Pleistocene temperatures: Jour. Geology, v. 63, no. 6, p. 538-573.

Flint, R. F., and Rubin, Meyer, 1955, Radiocarbon dates of pre-Mankato events in eastern and central North America : Science, v. 121, no. 3149, p. 649-658.

Highway Research Board, 1952, Frost action in soils, a symposium, special rept. no. 2 ; K. B. Woods, Chairman. 385 p.

Hough, J. L., 1953, Pleistocene climatic record in a Pacific Ocean core sample: Jour. Geology, v. 61, no. 3, p. 252-262.

Joffe, J. S., 1949, Pedology, 2d ed. : Pedology Publications, 662 p.

Johnson, A. W., 1952, Frost action in roads and airfields, a review of the literature: Highway Research Board, spec. rept. no. 1, 287 p.

Jumikis, A. R., 1954, Suction force in soils upon freezing: Am. Soc. Civil Eng. Proc., v. 80, Separate no. 445, p. 445-1 to 445-14.

Karlstrom, T. N. V., 1950, Preliminary geologic map of lowlands, Anchorage area, Alaska : U.S. Geol. Survey open-file rept:, 1 map.

- _ 1955, Late Pleistocene and Recent glacial chronology of south-centrat Alaska : Geol. Soc. America Bull., v. 66, no. 12, p. 1581 (abst.).

,- 1957 , Tentative correlation of Alaskan sequences, 1956 : Science, v. 125, no. 3237, p. $73-74$.

Kay, G. F., 1931, Classification and duration of the Pleistocene period: Geol. Soc. America Bull., v. 42, p. 425-466.

Kellogg, C. E., and Nygard, I. J., 1951, Exploratory study of the principal soil groups of Alaska : U.S. Dept. Agr., Mon. no. 7, 138 p.

Kulp, J. L., 1952, The carbon-14 method of age determination: Sci. Monthly, จ. 75, no. 5, p. 259-267.

Kulp, J. L., Feely, H. W., and Tryon, L. E.; 1951, Lamont natural radiocarbon measurements, I : Science, v. 114, no. 2970, p. 265-268.

Kulp, J. L., Tryon, L. E., Eckelman, W. R., and Snell, W. A., 1952, Lamont naturaI radiocarbon measurement II : Science, v. 116, no. 3016, p. 409-414.

Martin, G. C., 1906, A reconnaissance of the Matanuska coal field, Alaska, in 1.905 : U.S. Geol. Survey Bull. 289, 36 p.

Martin, G. C., 1919, The Alaskan mining industry in 1917 : U.S. Geol. Survey Bull. 692, p. 11-42.

Martin, G. C., 1920, The Alaskan mining industry in 1918 : U.S. Geol. Survey Bull. 712, p. 11-52. 


\section{SURFICIAL GEOLOGY OF ANCHORAGE AND VICINITY, ALASKA}

Mendenhall, W. C., 1900, A reconnaissance from Resurrection Bay to Tanana River, Alaska, in 1898: U.S. Geol. Survey 20th Ann. Rept., pt. 7, p. 265-340.

Morton, J. O., Tremper, Bailey, Stokstad, O. L., and Casagrande, Leo, 1938, Prevention of detrimental frost heave: in Soils Mechanics and Soils Stabilization, Highway Research Board Proc., v. 18, pt. II, p. 356-365.

Moxham, R. M., and Eckhart, R. A., 1956, Marl deposits in the Knik Arm area, Alaska : U.S. Geol. Survey Bull. 1039-A, 23 p.

Otis, P. S., 1952, Frost action and spring break-up: in Frost action in Soils, a symposium, Highway Research Board, spec. rept. no. 2, p. 268-274.

Park, C. F., 1933, The Girdwood district, Alaska: U.S. Geol. Survey Bull. 849-G, p. $381-424$.

Payne, T. G., 1955, Mesozoic and Cenozoic tectonic elements of Alaska: Misc. Geol. Inv. Map. I-84.

Péwé, T. L., Muller, E. H., Karlstrom, T. N. V., Krinsley, D. B., Fernald, H. T., Wahrhaftig, Clyde, Hopkins, D. M., and Detterman, R. L., 1953, Multiple glaciation in Alaska; a progress report: U.S. Geol. Survey Circ. 289, 13 p.

Rubin, Meyer, and Suess, H. E., 1955, U.S. Geological Survey radiocarbon dates II : Science, v. 121, no. 3145, p. 481-488.

- 1956, U.S. Geological Survey radiocarbon dates III : Science, v. 123, no. 3194, p. 442-448.

Ruckli, Robert, 1950, Der Frost im Baugrund [The frost in soil], Springer, Vienna.

$\longrightarrow, 1955$, Discussion of "Suction forces in soils upon freezing" by Alfreds R. Jumikis; Am. Soc. Civil Eng. Proc., v. 81, Separate no. 656, p. 656-5 to 656-6.

Schafer, J. P., 1949, Some periglacial features in central Montana : Jour. Geology, v. 57, no. 2, p. 154-174.

Sharp, R. P., 1942, Periglacial involutions in northeastern Illinois : Jour. Geology, v. 50, no. 2, p. 113-133.

Shrock, R. R., 1948, Sequence in layered rocks: New York, McGraw-Hill Co., Inc., $507 \mathrm{p}$.

Skelton, R. R., 1940, Field observations of frost heave: in Symposium on frost action, Proceedings of Purdue Conference on soil mechanics, p. 460-470.

Smith, P. S., 1909, Recent development in southern Alaska: U.S. Geol. Survey Bull. 379, p. 267-301.

$\longrightarrow, 1939$, Areal geology of Alaska: U.S. Geol. Survey Prof. Paper 192, 100 p.

Stokstad, O. L., 1952, Frost action in Michigan: in Frost action in Soils, a symposium, Highway Research Board spec. rept. no. 2, p. 278-280.

Suess, H. E., 1954, U.S. Geological Survey radiocarbon dates I : Science, v. 120, no. 3117, p. $467-473$.

— 1956, Absolute chronology of the Last Glaciation: Science, v. 123, no. 3192, p. 355-357.

Taber, Stephen, 1929, Frost heaving: Jour. Geology, v. 37, no. 5, p. 428-461. p. 198.

Trainer, F. W., 1953, Preliminary report on the geology and ground water resources of the Matanuska Valley agricultural area, Alaska: U.S. Geol. Survey Circ. 268, 43 p.

Twenhofel, W. H., 1939, Principles of Sedimentation: New York, McGraw-Hill Co., $610 \mathrm{p}$.

Twenhofel, W. S., 1952, Recent shore-line changes along the Pacific Coast of Alaska : Am. Jour. Sci., v. 250, p. 523-548. 
U.S. Coast and Geodetic Survey, United States Earthquakes [for years] 1936 et seq. 1954.

U.S. Corps of Engineers, 1951, Engineering Manual for Military construction, pt. 12, Chapter 4.

U.S. Dept. of Agriculture; Soils and Men, 1938: Year Book of Agriculture, 1938, $1232 \mathrm{p}$.

U.S. Weather Bureau, 1954, Climatological data, national summary, Annual 1953, v. 4, no. 13, 36 p.

Varnes, D. J., 1958, Landslide types and processes, p. 20-45, Chapter 3 in Landslides and Engineering Practice, Committee on Landslide Investigations, E. B. Eckel, Editor, Highway Research Board, Nat. Research Council. Special Report No. 29, NAS-NRC Publ. 544.

Watkins, W. I., 1945, Observations on the properties of loess in engineering structures: Am. Jour. Sci., v. 243, no. 5, p. 294-303.

Watkins, W. I., and Aarons, Henry, 1931, The soil profle and subgrade survey: Public Roads, v. 12, no. 7, p. 181-194.

Wilde, S. A., 1946, Forest soils and Forest growth : Chronica Botanica Co., 241 p. New series of plant Science Books, $\nabla$. XVIII.

Winn, H. F., 1940, Frost action in highway subgrades; in Symposium on frost action: Proceedings of Purdue Conference on soil mechanics, p. 444-457.

Winterkorn, H. F., 1947, Fundamental similarities between electro-osmotic and thermo-osmotic phenomena: Highway Research Board Proc., 27th Ann. Mtg., v. 27, p. 443-445.

$\longrightarrow, 1954$, Discussion of "Suction forces in soils upon freezing" by Alfreds R. Jumikis; Am. Soc. Civil Eng. Proc., v. 81, Separate no. 656, p. 656-6 to 656-9.

Wood, H. O., and Neumann, Frank, 1931, Modified Mercalli Intensity scale of 1931 : Seismol. Soc. America Bull., v. 21, p. 277-283.

Zeuner, F. E., 1945, The Pleistocene period; its climate, chronology, and faunal successions : Roy. Soc., Mon. 130 ; 332 p., London, Bernard Quaritch, Ltd. 



\section{INDEX}

Page

A bandoned-channel deposits

in ground moraine

Abstract.

Accessibility, of report area

Acknowledgments.

Advance outwash, definition

Aerial photographs.

Aggregate, crushed .

Alluvium.

Anchorage, city of

Argillite

54-56, 70-73

$54,55,61,71,72$

1-2

3

4

17

17

$-99$

82-83

3

Ash, volcantc

$78,79,81$

Ballast

99

Bootlegger Cove clay ....................... 12, 14,

$15,25,29,30,33,34,35-48,58,60,65,69,103,107$ clay analyses.

marine mollusks

origin.

type locality

$46-47$

45

41-48

Boulders.

Brick clay

$23,24,33,45,68,96$

Bridge, Alaska Railroad

10,92

Cairn Point $37,40,41,57,60$

Campbell Creek $5,21,37,47,71,72,82$

Carbon-14 age determinations.

$18,32,57,68,80,89,91$

Caribou Hills glaciation

Chester Creek. $5,35,37,69,71,72,76,81,82$

Ohugach Mountains................... 11, 21, 83-84

Clay minerals, analysis of . . ............... 25, 46-47

Climate ..................................... $7-8$

Clunie Creek ......................... 61, 71, 77,82

Cosl............................. 10, 18, 28, 31, 34, 68, 92

Cobbles................................ 23, 24, 27, 50

Construction materials . . . . . . .

Cook Inlet . .......................... 2-3, 89-91,94

Delta deposits............................. 26-34

Dlatoms, lacustrine......................... 19

Drainage............................... 5, 107-108

Drumlins............................... 23, 25, 56, 62

Dune sand ................................ 80-81

Eagle River.......... 5 5, 10, 24, 57, 65, 69-70, 72, 82, 86

Eagle River Flats............ 11, 17, 58,61, 62,81, 82, 87

Eagle River glacier............................ 69

Earthquakes............................. 104-105

Economic geology ........................... 92-111

Eklutna glaciation, deposits of ................ 11

Elmendorf Moraine ............... 25, 57, 59, 60,61, 72

Engineering problems....................... 99-111

Erosion.............................. 73,88-89,91

Eskers................................. 14, 23, 49, 52

Excavation............................... 103

Expedition, Army, 1898
Page

Fill_.......................................... 99

Fire Island . .............................. 31-33, 89

Flows . ................................. 37, 103-107

Fossil Creek.................... 59-60,64, 70, 71,86

Fossils................................ 18, 20, 45

Foundation, condition of .................. 99-103

Frost heave . ....................... 66-67, 108-11]

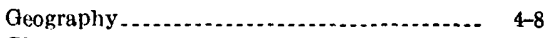

Glacial drift, undifferentlated............... $\quad 76$

Glenn Highway ........................... 3, 24, 25

Gold ....................................... 2-3

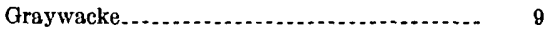

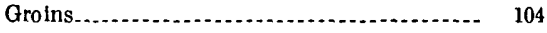

Highways, serving Anchorage area............ 3

History, geologic. ............................ 83-91

Ice-contact deposits, glaciofluvial............ 48-52

Illinoian glacial stage, estimated age.......... 16

Inoceramus sp. ............................. 9

Introduction . .............................. 2-3

Investigation, present ........................ $\quad 3-4$

Involutions, caused by frost action . .......... 67

Isostatic adjustment........................... 33,73

Jewel Lake..................... 26, $34,40,45,48,54$

Kame terraces........................... 12, 63-65

Kames .................. 14, 15, 26, 49, 51, 52, 56, 59,60

Kettles........................................ 14, $15,21,23,26,27,56,59,60,61-62,63,64-65,67$, 70,74

Knlk Arm.................... 11, 62, 81, 83, 87, 88-89

Knik glaciation, abandoned-channel deposits.. 54-56 advance outwash .......................... 17-21 Bootlegger Cove clay ............ 12, 14, 35-48, 103 delta deposits................................ 26-34 deposits of ................................. 12-56 glaciofluvial ice-contact deposits....... 13, 48-52 ground moraine....................... 13, 23-20 lateral moraine ...................... 13, 21-23,84 pitted outwash ........................... 52-54

prodelta deposits......................... 34-35

Knik loam . ................................. 6

Leaching..................................... 6

Limestone..............

chemical analyses of ...................... 9,92 metamorphosed, for use as crushed aggregate........................... 96

Little Rabbit Creek .... 3, 9, 21, 36, 41, 75, 76, 82, 92-93

Location, of report area...................... 3

Loess_.......................................... 73,83

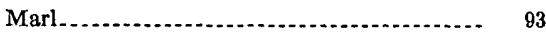

Matanuska River valley............... 10, 18, 20, 83 
Mercalli Scale, Modified, for measuring intensity of earthquake shocks... 104-105

Montmorillonite

Moraine, end

ground

lateral.

Mount Susitna

Muskegs

Naptowne glaciation, abandoned-channel deposits.

advance outwash

deposits of

end moraine.

ground moraine.

kame field and kame terrace deposits

outwash.

pitted outwash

silt.

73-74

Outwash, pitted $52-54$

Oxidation, depth of ...................... 11, 14, 16, $22,24,25,33-34,39,40,48,53,57,75,83,85$

Peat

Photointerpretation.................................. $15,16,18,20,36,57,68,79,80,91,93$

Physiography.

Podzol soil ................................. 6,87

Point Campbell............ 10, 26, 27, 28, 31, 32, 88, 92

Point Woronzof............ 10, 26, 29, 31, 33, 88-89, 92

Pollen, analysis of.

Precipitation

Pre-Cretaceous(?) rocks.

8-10

Pre-Quaternary rocks.

Pre-Wisconsin deposits

Prodelta deposits

Quaternary deposits. 10-83

Rabbit Creek $5,17,21,55,75,76,82$

Railroad, Alaska cuts along. 17,69

Resources, mineral $92-111$

Riprap 95-96

Rocks, metamorphic, for use as crushed aggregate.
Page

Russian Jack Springs......................... 94

Sand and gravel............................ 63, 99

Sand Lake.................................. 34, 54

Sangamon glacial stage, estimated age ........ 16

Ship Creek................ 5, 24, 35, 70, 73, 75, 77,82, 86

Silt, eolian ................................ 73-74

estuarine . . . . . . . . . .

Sixmile Creek ....................... 58,61, 65, 71, 82

Ski Bowl Road............................... 24,75

Slumps....................... 37, 58, 59,65, 67, 103-107

Soll binder. . .

Soils_.......................................... 6

Sphagnum moss........................ 6, 79,80

Springs................................ 58,62,94, 104

Stereoscopic examination, of aerial photographs.............................. 4

Sundi Lake............................. 34, 54

Swamps............................. 5, 78-80, 102, 107

Swan Lake deposits. ........................ 15

Swan Lake glaciation........................... 15

Temperature........ 7

Tertiary rocks................................ 10

Thermo-osmosis........................... 108

Till..... 21, 24, 25, 26, 28, 30, 32, 36, 60, 62, 76, 84, 102, 107

Topography, of deposits of Wisconsin age ..... 56-57

Turnagain Arm . ............................ 3, 17,

Tustumena Lake.......................... 11

Varves...................................... 46

Vegetation . . .

Water........................................... 93-95

Well logs, cited in text..................... 111-122

records of

Wells, water.............................. 73,94-95

Wind, prevailing................................ 8

Wisconsin deposits. ........................... $56-74$

Zola, Russian word as root of the name "podzol" 